\title{
The history of mining and mineral exploration in Panama: From Pre-Columbian gold mining to modern copper mining
}

\section{La historia de la minería y la exploración minera en Panamá: De la minería de oro precolombina a la minería moderno de cobre}

\author{
Stewart D. Redwood ${ }^{1, *}$
}

${ }^{1}$ Consulting Economic Geologist, P.O. Box 0832-0757, World Trade Center, Panama City, Panama.

* Corresponding author: (S. D. Redwood) stewart@sredwood.com

\section{How to cite this article:}

Redwood, S.D., 2020, The history of mining and mineral exploration in Panama: From PreColumbian gold mining to modern copper mining: Boletín de la Sociedad Geológica Mexicana, 72 (3), Al80720. http://dx.doi. org/10.18268/BSGM2020v72n3a180720

Manuscript received: May 25, 2020

Corrected manuscript received: June 26, 2020 Manuscript accepted: June 26, 2020

Peer Review under the responsability of Universidad Nacional Autónoma de México.

This is an open access article under the CC BY-NC-SA license(https://creativecommons.org/licenses/by-nc-sa/4.0/)

\section{ABSTRACT}

The history of mining and exploration in Panama is a case study of the evolution of mining in a tropical, island arc environment in the New World from prehistoric to modern times over a period of $\sim 1900$ years. Panama has a strong mineral endowment of gold $(\sim 984 \mathrm{t})$, and copper $(\sim 32$ Mt) resulting in a rich mining heritage. The mining history can be divided into five periods. The first was the pre-Columbian period of gold mining from near the start of the Current Era at $~ 100 \mathrm{CE}$ to 1501, following the introduced of gold metalwork fully fledged from Colombia. Mining of gold took place from placer and vein deposits in the Veraguas, Coclé, Northern Darien and Darien goldfields, together with copper for alloying. Panama was the first country on the mainland of the Americas to be mined by Europeans during the Spanish colonial period from 1501-1821. The pattern of gold rushes, conquest and settlement can be mapped from Spanish records, starting in Northern Darien then moving west to Panama in 1519 and Nata in 1522. From here, expeditions set out throughout Veraguas over the next century to the Veraguas (Concepción), Southern Veraguas, Coclé and Central Veraguas goldfields. Attention returned to Darien in $~ 1665$ and led to the discovery of the Espíritu Santo de Cana gold mine, the most important gold mine to that date in the Americas. The third period was the Republican period following independence from Spain in 1821 to become part of the Gran Colombia alliance, and the formation of the Republic of Panama in 1903. This period up to $\sim 1942$ was characterized by mining of gold veins and placers, and manganese mining from 1871 . Gold mining ceased during World War Two. The fourth period was the era of porphyry copper discoveries and systematic, regional geochemical exploration programs from 1956 to 1982 , carried out mainly by the United Nations and the Panamanian government, as well as private enterprise. This resulted in the discovery of the giant porphyry copper deposits at Cerro Colorado (1957) and Petaquilla (Cobre Panama, 1968), as well as several other porphyry deposits, epithermal gold deposits and bauxite deposits. The exploration techniques for the discovery of copper were stream sediment and soil sampling, followed rapidly by drilling. The only mine developed in this period was marine black sands for iron ore (1971-1972). The fifth and current period is the exploration and development of modern gold and copper mines since 1985 by national and foreign companies, which started in response to the gold price rise. The main discovery methods for gold, which was not analyzed in the stream sediment surveys, were lithogeochemistry of alteration zones and reexamination of old mines. Gold mines were developed at Remance (1990-1998), Santa Rosa (1995-1999 with restart planned in 2020) and Molejon (2009-2014), and the Cobre Panama copper deposit started production in 2019. The level of exploration in the country is still immature and there is high potential for the discovery of new deposits.

Keywords: Epithermal gold, porphyry copper, manganese, bauxite, pre-Columbian mining, Spanish colonial mining, exploration methods.

\section{RESUMEN}

La historia de la minería y la exploración en Panamá es un estudio de caso de la evolución de la minería en un ambiente tropical de arco insular en el Nuevo Mundo desde la prehistoria hasta los tiempos modernos durante un período de $\sim 1900$ años. Panamá tiene una fuerte dotación mineral de oro ( 984t) y cobre $(\sim 32 \mathrm{Mt})$, lo que resulta en un rico patrimonio minero. La historia minera se puede dividir en cinco periodos. El primero fue el período precolombino de extracción de oro desde cerca el inicio de la Era Común 100 EC-1501 después de la introducción de la metalurgia de oro en toda regla desde Colombia. La extracción de oro se realizó a partir de depósitos de placer $y$ vetas en los distritos auriferos de Veraguas, Coclé, Darién del Norte y Darién, junto con cobre para alear. Panamá fue el primer país en el continente de las Américas en ser explotado por los europeos durante el período colonial español de 1501-1821. El patrón de la fiebre del oro, la conquista y el asentamiento se puede mapear a partir de los registros españoles, comenzando en el norte de Darién y luego avanzando hacia el oeste hasta Panamá en 1519 y Natá en 1522. Desde aquí, las expediciones partieron por Veraguas durante el próximo siglo en los distritos auriferos de Veraguas (Concepción), sur de Veraguas, Coclé y el centro de Veraguas. La atención regresó a Darién en $\sim 1665$ y llevo al descubrimiento de Espíritu Santo de Cana, la mina de oro más importante hasta esa fecha en las Américas. El tercer periodo fue el período republicano después de la independencia de España en 1821 para formar parte de la alianza de Gran Colombia, y la formación de la República de Panamá en 1903. Este periodo hasta 1942 se caracterizó por la minería de vetas y placeres de oro, y la minería de manganeso desde 1871. La minería de oro cesó durante la Segunda Guerra Mundial. El cuarto período fue la era de los descubrimientos de pórfidos de cobre y los programas sistemáticos de exploración geoquímica regional desde 1956 hasta 1982, llevados a cabo principalmente por las Naciones Unidas y el gobierno panameño, así como por la empresa privada. Esto resultó en el descubrimiento de los depósitos de pórfido de cobre gigantes en Cerro Colorado (1957) y Petaquilla (Cobre Panamá, 1968), así como en otros depósitos de pórfido, depósitos de oro epitermal y depósitos de bauxita. Las técnicas de exploración para el descubrimiento de cobre fueron el muestreo de sedimentos y suelos, y la perforación. La única mina desarrollada en este periodo fue de arenas negras marinas para mineral de hierro (1971-1972). El quinto y actual período es la exploración y desarrollo de minas modernas de oro y cobre desde 1985 por parte de compañias nacionales y extranjeras, que comenzaron en respuesta al aumento del precio del oro. Los principales métodos de descubrimiento de oro, que no se analizaron en los estudios de sedimentos de la corriente, fueron la litogeoquímica de las zonas de alteración y el reexamen de las antiguas minas. Las minas de oro se desarrollaron en El Remance (1990-1998), Santa Rosa (1995-1999 con reinicio planificado en 2020) y Molejón (2009-2014), y el depósito de cobre Cobre Panamá comenzó a producir en 2019. El nivel de exploración del país es aún inmaduro y existe un alto potencial para el descubrimiento de nuevos depósitos.

Palabras clave: oro epitermal, pórfido de cobre, manganeso, bauxita, minería precolombina, minería colonial española, técnicas de exploración. 


\section{Introduction}

The history of mining in Panama is a fascinating case study of the evolution of mining in the New World from prehistoric times to modern times over a time period of approximately 1900 years (Carles, 1962; Mérida, 1973; Castillero Calvo, 2008, 2004, 2019; Méndez, 2013). The country already had a thriving indigenous gold mining industry in the order of 1400 years old at the time of the Spanish conquest. The golden chieftains had spectacular gold adornments to rival those of Peru, and new archaeological discoveries continue to be made such as that at El Caño in 2010 (Williams and Coventry, 2012). Panama was the first mainland country of the Americas to be mined by Europeans. The Spanish conquest was the greatest gold rush in history, and Panama was one of the most important gold producers. The Spaniards built on the indigenous gold mining technology and introduced new manpower from Africa as well as new technology. The pattern of gold rushes that drove conquest can be reconstructed in some detail. Interestingly, not all gold rushes led to permanent settlement in areas that were unsuitable for agriculture such as northern Veraguas and
Darien, resulting in their abandonment, and due in part, also, to pirate raids on the remote mines and Indian uprisings. Vein and placer gold mining continued through the republican period up until World War Two, and manganese mining began in the late $19^{\text {th }}$ century.

The modern period of exploration began in the second half of the twentieth century and saw the systematic exploration of virtually the whole country leading to the discovery of many new copper and gold deposits, including two giant copper deposits in new metallogenic belts. The development of modern gold and copper exploration and mining has taken place since 1985, and the first giant copper deposit has started production in one of the biggest mines in the world, which will make Panama one of the largest copper producers in Latin America.

The objective of this paper is to describe the history of mining and mineral exploration in Panama. It is a companion paper to the geological description of the mineral deposits of Panama (Redwood, 2020c). The history is based on the published archaeological, historical, geological and mining literature, historical newspapers, company press releases and financial reports,

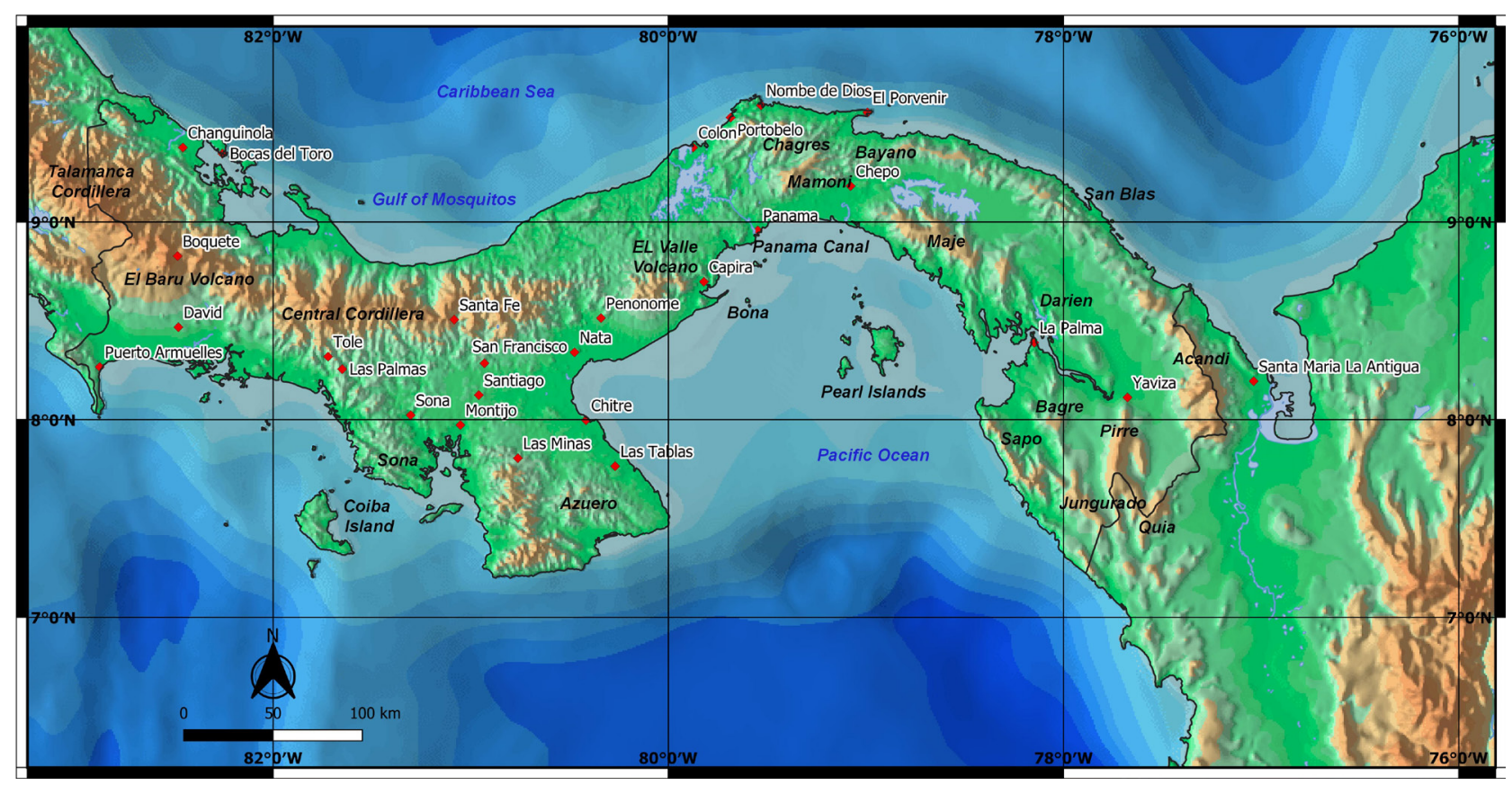

Figure 1 Digital elevation model of Panama showing the names of the main topographic features, cities and towns (map by S. Redwood). 


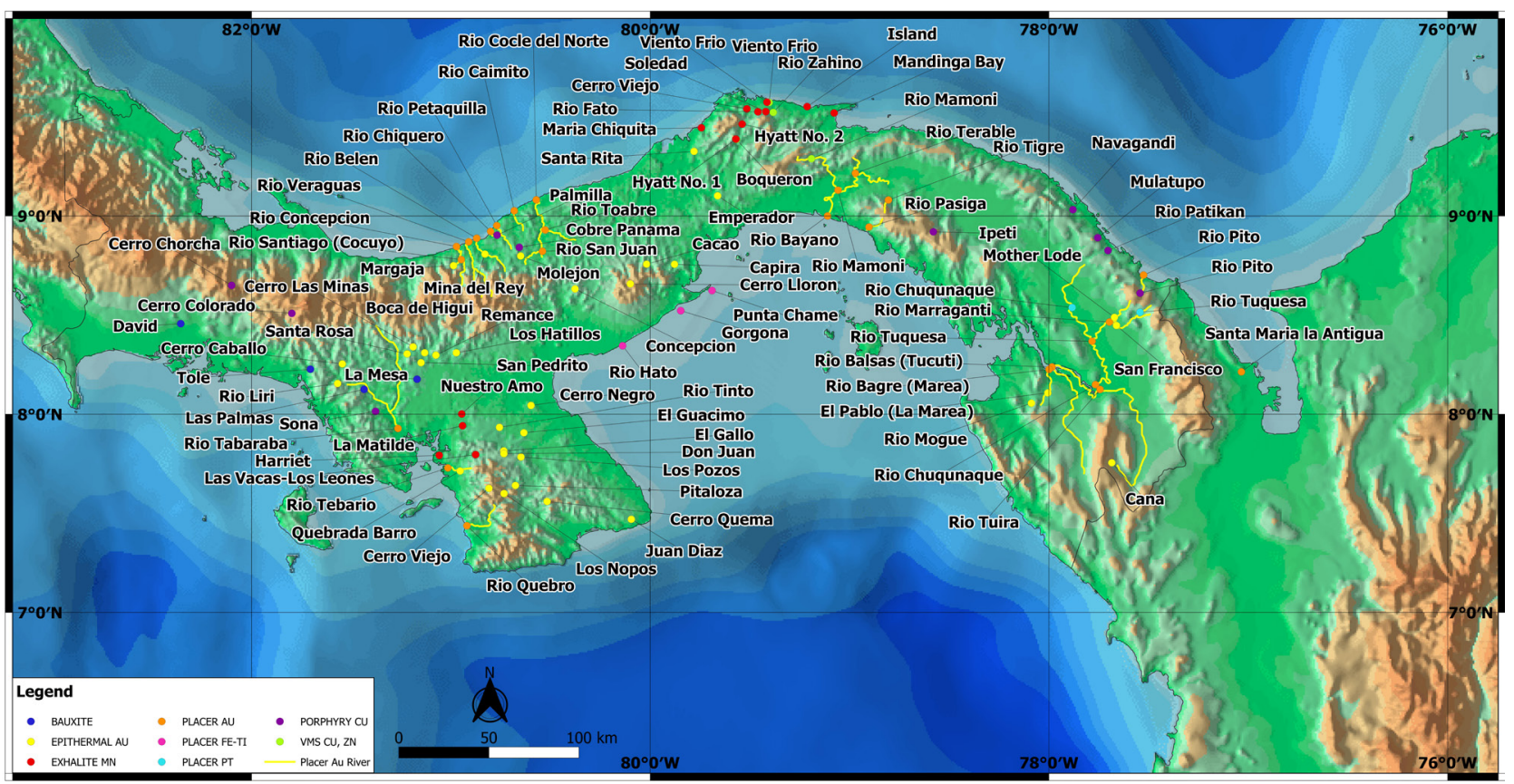

Figure 2 Location map of the principal mineral deposits and prospects of Panama (map by S. Redwood).

Canadian Securities Administrators' NI 43-101 technical reports published on Sedar (www.sedar. com), and company archives (Thayer Lindslay Papers, American Heritage Center, University of Wyoming; The National Archives, London), as well as the author's quarter century of exploration experience in Panama.

\section{Exploration and mining history of Panama}

Exploration and mining in Panama can be divided into five historical periods (Table 1, Figures 1, 2): 1) the pre-Columbian period of gold mining, 100 CE-1501; 2) the Spanish colonial period of gold mining, 1501-1821; 3) the Republican period of gold mining, 1821-1942, and manganese mining from 1871 ; 4) the period of porphyry copper discoveries and regional exploration programs from 1956 to 1982; and 5) the development of modern gold and copper exploration and mining from 1985 to the present.

The total metal endowment (historical production plus resources) of the isthmus is about 32 Mt $\mathrm{Cu}$ and $984 \mathrm{t} \mathrm{Au}$ (31.6 Moz), of which doc- umented gold production was about 96.5 t (3.1 Moz) and copper production was negligible until 2019 (Redwood, 2020c). These figures underestimate much of the historical gold production for which there are no records. In the Gold Deposits of the World, Emmons ranked Colombia, which included Panama for most of the period in question, as the number one gold producer in South America from 1493 to 1934 with an estimated 49 Moz Au (1,524 t) (Emmons, 1937, p. 256). Panama was the third most important gold producing province in Colombia from 1537 to 1890 with $14 \%$ of the production (after Antioquia with 38\% and Cauca with 37\%) (Restrepo, 1952). Applying this proportion to Emmons' total indicates that Panama's share was about 6.9 Moz Au (213 t). It is clear that Panama's historical importance as a gold producer has been underestimated.

\section{Pre-Columbian mining}

\subsection{OVERVIEW}

Panama was situated in the Intermediate Area between the Maya civilization of Mesoamerica 
Table 1. Summary of the history of mining and exploration in Panama.

\begin{tabular}{|c|c|}
\hline Dates & Events \\
\hline & Period 1 Pre-Columbian \\
\hline \multirow{3}{*}{$\begin{array}{l}\sim 100 \mathrm{CE} \\
\sim 100-1501\end{array}$} & Gold metalwork introduced from Colombia. \\
\hline & Indigenous gold and minor copper mining from placer and vein deposits. \\
\hline & $\begin{array}{l}\text { Period } 2 \text { Spanish Colonial } \\
\end{array}$ \\
\hline $1501-1821$ & $\begin{array}{l}\text { Spanish colonial era and gold rush in Tierra Firme and Castilla de Oro. It was called the Real Audiencia of Panama y Reyno } \\
\text { de Terra Firme (1538-1751) and the Comandancia General de Tierra Firme (1751-1821). It was part of the Viceroyalty of } \\
\text { Peru (1542-1739) and then the Viceroyalty of New Granada (1739-1821). }\end{array}$ \\
\hline 1501 & Rodrigo de Bastidas discovery of eastern Panama (San Blas). \\
\hline $1502-1503$ & Christopher Columbus discovery of Veraguas and Veraguas gold district, and visited Indian gold mines. \\
\hline $1510-1526$ & Santa María de la Antigua del Darien founded. Gold mined until 1524, at Acla from 1520, and at Rio Pito. \\
\hline 1519 & Panama City founded. Gold mined in Panama district from 1520 at Rio Pequeni, Rio Puente, Gracias a Dios and other places. \\
\hline 1522 & Nata de los Caballeros founded. Gold mined in the district from 1523. \\
\hline $1559-1589$ & Concepcion (Turluru) placer and veins mined in Veraguas. \\
\hline $1599-1604$ & San Juan de Mariato (Azuero) placer gold mined. \\
\hline $1603-1605$ & Cocle gold belt conquered. Nueva Lisboa established on Rio Cocle del Norte then moved to Rio Belen. \\
\hline $1608-1619$ & Nuestra Señora de la Regla (Montijo) placer gold mined. \\
\hline$\sim 1620$ & Central Veraguas Gold Belt discovered, San Francisco de la Montana founded by 1623. \\
\hline$\sim 1665$ & Alluvial gold mining in Darien started with founding of El Real de Santa María on the Rio Tuira. \\
\hline$\sim 1675-1727$ & High grade Espiritu Santo de Cana gold mine in Darien mined. \\
\hline \multirow[t]{2}{*}{1703} & Capira new gold veins discovered. \\
\hline & Period 3 Republic \\
\hline 1821 & $\begin{array}{l}\text { Independence from Spain as part of the Republic of Colombia or Gran Colombia (1821-1830), Republic of New Granada } \\
(1830-1861) \text {, United States of Colombia (1861-1886) and Republic of Colombia (1886-1903). }\end{array}$ \\
\hline $1850-1855$ & Panama Railroad built, the first trans-continental railroad in the Americas. \\
\hline 1871 & Manganese mining began in the Nombre de Dios belt. \\
\hline $1888-1926$ & Espiritu Santo de Cana gold mine reopened. \\
\hline 1899-1902 & The Thousand Day War in Colombia and Panama. \\
\hline 1903 & Republic of Panama founded on independence from Colombia. \\
\hline 1904-1914 & Panama Canal built. \\
\hline 1917 & New Panamanian Mining Code replaced old Mining Code of Antioquia and led to a claim staking boom. \\
\hline \multirow[t]{2}{*}{$1927-1942$} & $\begin{array}{l}\text { Panama Corporation Ltd, England, 1927-1931 explored large concessions for vein and placer gold and developed several } \\
\text { mines in the Central Veraguas Gold Belt, Capira and Margaja. Restructured as the Panama Corporation (Canada) Ltd in } 1932 . \\
\text { Gold mining suspended in } 1942 \text { by the war. Company closed between } \sim 1945-1951 \text {. }\end{array}$ \\
\hline & Period 4 Porphyry Copper Discoveries \\
\hline 1956-1960s & Bauxite exploration in Chiriqui and Veraguas. \\
\hline 1957 & Cerro Colorado porphyry copper deposit discovered by a private company. \\
\hline 1963 & $\begin{array}{l}\text { Government mining authority created, and start of era of government and foreign aid-supported mineral exploration } \\
\text { reconnaissance programs, 1965-1991. }\end{array}$ \\
\hline 1964 & New mining law. \\
\hline $1965-1974$ & $\begin{array}{l}\text { UNDP mineral reconnaissance programs. Discovered Cerro Quema Cu anomaly (1967), and Cu porphyries at Petaquilla } \\
\text { (1968), Palmilla (1969), Rio Pito (1970) and lpeti (1971). }\end{array}$ \\
\hline 1969-1976 & Cerro Chorcha porphyry $\mathrm{Cu}$ discovered in a regional stream sediment survey by Asarco, but did not drill. \\
\hline 1971-1972 & Marine black sands mined for Fe-Ti at Gorgona-Bona by Hierro Panama, a Japanese-Panamanian joint venture. \\
\hline \multirow[t]{2}{*}{ 1969-1982 } & $\begin{array}{l}\text { Resource definition and feasibility studies carried out of Cerro Colorado (1969-1982) and Petaquilla (1971-1980) copper } \\
\text { deposits by foreign companies but they were not economic at the time. }\end{array}$ \\
\hline & Periond 5 Modern Mining \\
\hline $1985-2000 \mathrm{~s}$ & Exploration for $\mathrm{Au}$ and $\mathrm{Cu}$ by foreign companies. \\
\hline 1989 & US invasion of Panama to restore democracy. \\
\hline 1990-1998 & Remance underground gold mine in operation. \\
\hline 1991-1998 & $\begin{array}{l}\text { Petaquilla explored again by a Canadian consortium of Minnova/lnmet, Adrian and Teck, with a new feasibility study, but } \\
\text { suspended due to low copper price. }\end{array}$ \\
\hline $1993-2005$ & Cerro Colorado explored again with a new feasibility study. \\
\hline 1995-1999 & Santa Rosa gold mine in production as the first open pit mine in Panama. \\
\hline 1999 & Panama Canal returned to Panama by US. \\
\hline 2003 & $\begin{array}{l}\text { Petaquilla project reactivated, ownership consolidated by lnmet and name changed to Cobre Panama. Started mine } \\
\text { construction } 2011 \text {. }\end{array}$ \\
\hline 2005-2011 & Cerro Colorado bid prepared, but project cancelled due to Indian opposition. \\
\hline 2009-2014 & Molejon gold mine in operation. \\
\hline 2013 & First Quantum Minerals Ltd bought lnmet and the Cobre Panama project. Restarted construction in 2014. \\
\hline 2016 & Panama Canal expansion opened. \\
\hline 2017 & Environmental study submitted for oxide gold mine at Cerro Quema. \\
\hline 2019 & Cobre Panama copper mine started production. \\
\hline 2020 & Planned restart of Santa Rosa gold mine. \\
\hline
\end{tabular}


and the Inca civilization of the Central Andes. There has been continuous human occupation of Panama since the end of the Pleistocene in Palaeoindian times (12,000-11,200 cal BCE). It was inhabited mainly by people of the Cueva ethnic and linguistic group, ancestors of the present-day speakers of Chibchan or Chocoan group languages. Panama has been divided into three cultural areas, Gran Darien, Gran Coclé and Gran Chiriqui for the last 2,000 years of the pre-Columbian period. These were ruled by chiefs or caciques in multiple chiefdoms (Cooke, 2005; Cooke et al., 2019; Cooke and Sánchez Herrera, 2019).

The first gold artefacts are found in Panama near the beginning of the Common Era. Gold metal-working technology, or metallurgy in the archaeological sense, was introduced fully-fledged into Panama from Colombia, specifically the fron- tier area around the Gulf of Urabá, where Andean (Quimbaya) influences blended with those from the Caribbean lowlands. It is assumed that Panamanians started both mining and metal-working of gold at this time. Local stylistic traits appear in Panamanian metalwork perhaps as early as the $2^{\text {nd }}$ to $4^{\text {th }}$ centuries CE. (Cooke and Bray, 1985; Cooke et al., 2003, 2011; Bray et al., 2021). The oldest contextualized dated metal artefact is a copper ring worn by a young child associated with several fragments of gold ornaments found in a mortuary pit at Cerro Juan Díaz dated on a tooth from the child at $1700 \mathrm{cal} \mathrm{BP}(135-380 \mathrm{cal} \mathrm{CE})$ (Figure 4C; Cooke and Sánchez Herrera, 1998; Cooke et al., 2003; R. Cooke, personal communication, 31 May 2020, 9 July 2020). There is a rich legacy of gold artifacts from nine sites in Central Panama dated by pottery at 750-950 cal CE at Sitio Conte (Figures 4A and 4B; Lothrop, 1937), Cerro Juan

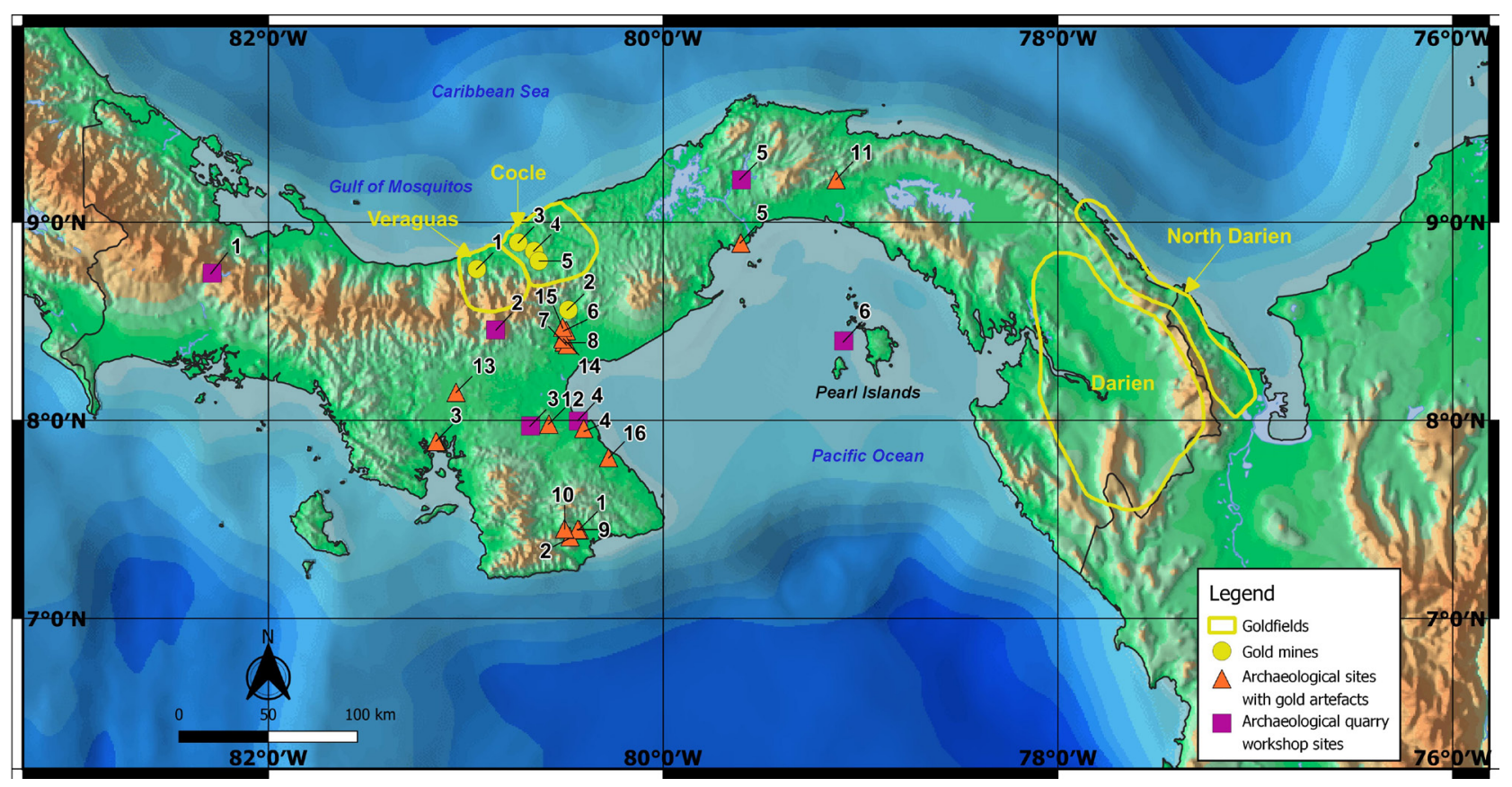

Figure 3 Map of pre-Columbian mining and metalwork in Panama, with the main goldfields outlined. Gold mines with historical references or archaeological sites (Griggs, 1998; Mayo et al., 2007): 1, Turlurú. 2, Cerro Cebollal. 3, DO-6 and DO-7, Rio Petaquilla (placer Au). 4, DO-22, Rio Botija (placer Au). 5, DO-14, Rio Mestizo (adits for vein Au). Sites 3-5 are probably Spanish Colonial. Archaeological sites of quarrying, mining and related activities (Pearson, 2003; Dickau et al., 2013; Cooke et al., 2016; Martin et al., 2016; Cooke et al., 2013): 1, Casita de Piedra (stone collection). 2, Laguna La Yeguada (quarries-workshops in volcanic rock). 3, Nieto (quarry-workshop on quartz vein). 4. La Mula-West (quarry-workshop for agate). 5, Chagres (quarry-workshop for chalcedony). 6, Playa Don Bernardo, Pedro Gonzalez Island (source and workshop for agate). Archaeological sites with gold artefacts (after Cooke et al., 2003, Table 1, numbered in approximate chronological order from oldest to youngest): 1, El Cafetal. 2, La India. 3, Las Huacas. 4, Cerro Juan Díaz. 5, Playa Venado. 6, Rancho Sancho. 7, Sitio Conte. 8, El Caño. 9, El Indio. 10, La Cañaza. 11, Miraflores. 12, El Hatillo, Finca Juan Calderon. 13, La Peña. 14, El Candil. 15, Toro Bravo. 16, Espavé, Guarare (Map by S. Redwood). 


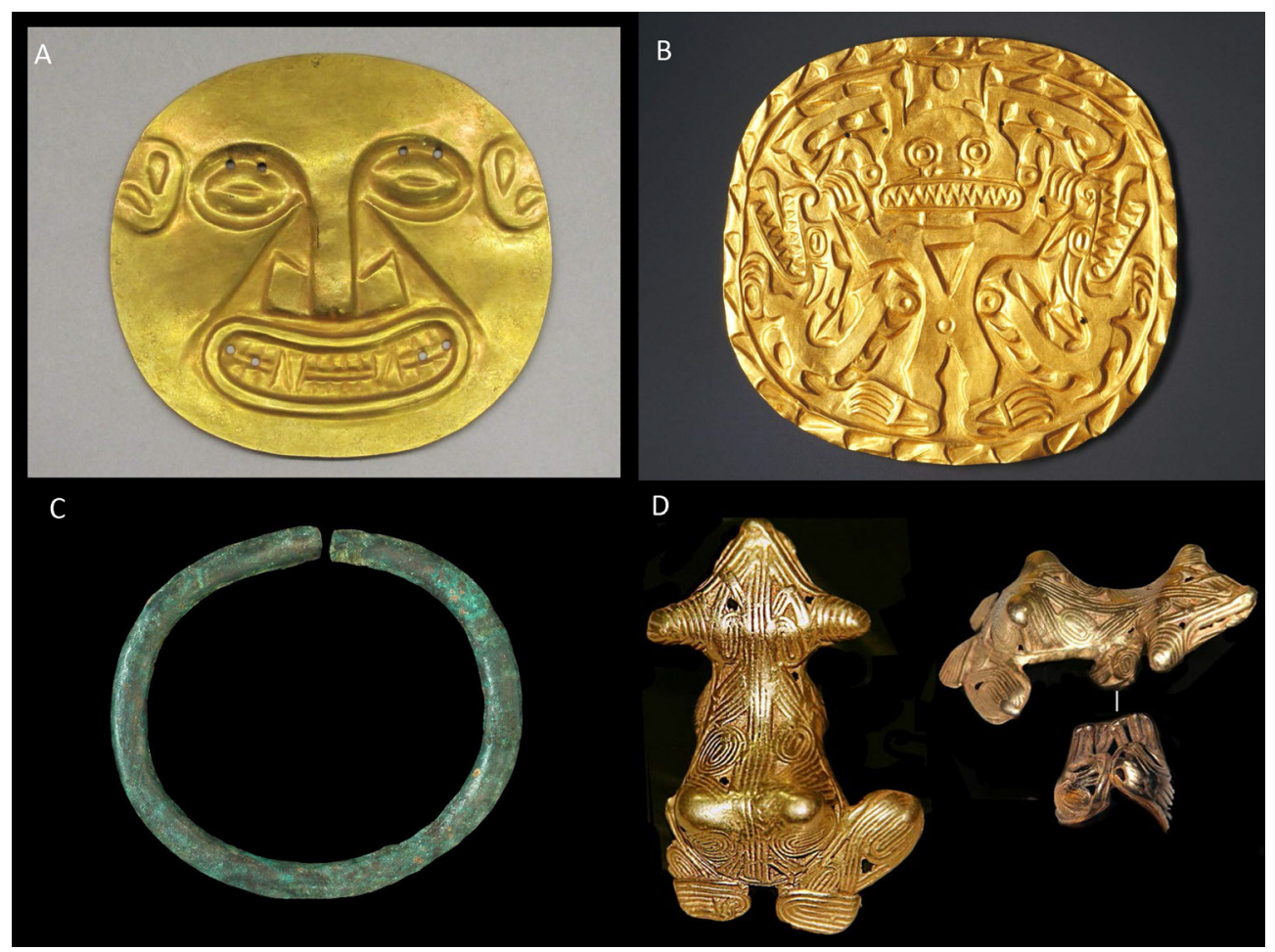

Figure 4 Examples of archaeological metalwork from burial sites in Panama. A) Embossed gold disk with human face and feline fangs, Sitio Conte, 700-1,000 CE. 10.2 x 10.2 cm. Brooklyn Museum, New York, Museum Expedition 1931, Museum Collection Fund, 33.448.6 (photo Brooklyn Museum, reproduced under Creative Commons-BY). B) Plaque of hammered gold with crocodile deity, Sitio Conte, 700-900 CE. 21.6 x 22.9 cm. Brooklyn Museum, New York, Museum Expedition 1931, Museum Collection Fund, 33.448 .12 (photo Brooklyn Museum, reproduced under Creative Commons-BY). C) Copper ring, Cerro Juan Díaz (catalogue number M-015), $5.5 \mathrm{~cm}$. This is the oldest contextualized dated metal artefact found in Panama. Found in Tomb 16, Operation 3, in association with a child aged 6-7 along with 31 dog-shaped Spondylus images, two polished stone bars, perforated longitudinally (one is agate and the other an unidentified blue stone), and 74 perforated canines of which 57 belonged to puma (Puma concolor), 12 to ocelot (Leopdardus pardalis), and four to raccoon (Procyon lotor). The teeth probably formed a necklace. The copper ring was suspended by twisted cotton string from the septum. A tooth from the child was AMS-dated to $1700 \pm 40$ cal. BP (135-380 cal. CE) (Cooke and Sánchez Herrera, 1998; image reproduced with permission of Richard Cooke; data courtesy of Nicole Smith-Guzmán). D) Open-work cast gold frog found on the Rio Majé, Darien (image by Richard Cooke and reproduced with his permission).

Díaz (Cooke and Sánchez Herrera, 1998), Playa Venado (Lothrop, 1956; Smith-Guzmán et al, 2021), El Caño (Mayo and Mayo, 2013; Mayo and Carles, 2015; Williams and Coventry, 2012), El Indio, Finca Juan Calderón, La Cañaza, Las Huacas, Miraflores, and Rancho Sancho (Cooke et al., 2003), most of which are located around Parita Bay in the western part of the Gulf of Panama, and around the Gulf of Montijo (Figure 3). There are also a few copper artefacts such as the copper ring already referred to at Cerro Juan Díaz (Figure 4C; Cooke and Sánchez Herrera, 1998) and a copper chisel at Sitio Conte, as well as many objects of copper-gold alloy known as tumbaga (Lothrop, 1937). The gold metalwork has been divided stylistically into an Initial Group (200-
$550 \mathrm{CE})$, an International Group (550-1000 CE) and later styles. This sequence does not have rigid divisions but rather groups and styles blend into each other. Regionalism is evident throughout. For example, the Conte Style is named because designs embossed on high carat hammered plaques (the "patenas" of the early Spanish chronicles; Figures $4 \mathrm{~A}$ and $4 \mathrm{~B}$ ) are very similar to designs painted on pottery at well-known archaeological sites such as Sitio Conte and El Caño. The International Group, consisting largely of cast animal and human figures (Figure 4D), was gradually phased out by the Conte Style in central Panama, and the Veraguas-Chiriqui Style in western Panama (Cooke and Bray, 1985; Bray et al., 2021). 
Gold was mined from placer deposits and veins as described in early Spanish accounts (Fernández de Oviedo, 1526; Colón, 1571; Jane, 1930; Cooke et al., 2003). Copper was often alloyed with gold and occasionally used in pure copper artefacts. Copper is not transported in rivers like placer gold and must have been mined in situ from copper deposits cropping out at the surface as copper oxides or native copper. (A unique exception which the author saw was native copper in quartz in river cobbles in the Dominican Republic; the cobbles were impossible to split even after breaking the quartz due to the malleability of the copper.) Copper ore for metal-working was found at the Sitio Conte graves where it was recorded as "oxidized copper ore" in grave 1 and "three lumps of copper" in grave 3 (Lothrop, 1937). Ingots of copper and gold were found in other graves, and were probably raw material for goldsmithing (Lothrop, 1937; Cooke et al., 2003).

Contact period Spanish documents show that gold mining was being carried out by indigenous people at the time of the conquest, which took place gradually over more than a century from 1501-1603, in the goldfields of Veragua (including the Turlurú mine), Coclé, Northern Darien, Darien and others (Figure 3). Gold was mined both from alluvial and vein deposits. There are several possible sources of copper, the principal ones being the Cocle goldfield where the giant Petaquilla (Cobre Panama) copper deposits are located; the Cerro Colorado and Cerro Chorcha copper deposits in the cordillera south of Chiriqui Lagoon to the west of the Veraguas goldfield, where native copper occurs (Linn et al., 1981a); copper occurrences in the headwaters of the Ríos Vigui, Cobre and Tabasará, Veraguas province (Terry, 1956); a copper-gold mine at Trota, near La Filipina, on the southeastern Soná peninsula near the Gulf of Montijo, recorded as early as 1560; a cluster of small copper deposits in northern Azuero (Herrera) near Ocú (Río Tinto), Las Minas (Don Juan) and Pesé (El Guácimo); and several small copper-gold prospects in southern Azuero (Los Santos and Veraguas provinces) such as Cerro Quema, Los Nopos and Quebrada Barro. In the
Northern Darien and Darien goldfields, there are copper deposits in the Darien Mountains in the Eastern San Blas, Río Pito and Acandi copper deposits, and also in the Majé range (Figure 2).

\subsection{ARCHAEOLOGICAL EVIDENGE FOR PRE- COLUMBIAN QUARRIES AND MINES}

There is archaeological evidence for pre-Columbian mining and quarrying at several sites in Panama (Figure 3). Palaeoindian (11,500-10,000 BP) lithic quarry-workshop sites have been identified in four places: 1) at Nieto, near Pesé (Herrera) on a quartz outcrop; 2) around Lake La Yeguada (Calobre, Veraguas) in the Central Cordillera, where ten quarry-workshops were identified in volcanic rocks; 3) at a locality near Lake Alajuela on the Río Chagres (Chilibre, Panama) where a large quarry-workshop for making chalcedony tools was found; and 4) at La Mula-West quarry-workshop on Parita Bay (Chitré, Herrera) where veins of agate were worked (Pearson, 2003; Cooke et al., 2013).

Agate was exploited from basalts at a site in the Pearl Islands to make stone tools between 6,200 and 5,600 cal BP. These were found at an accumulation of cultural debris at Don Bernardo Beach on Pedro González Island, the oldest Preceramic human settlement yet identified on the Pearl Island archipelago (Martín et al., 2016; Cooke et al., 2016). The agate vesicles and veins could have been quarried from the basalts, or collected by gathering weathered-out agate pebbles in the soil or on the beach.

Seven small possible ancient mine excavations in volcanic rocks were identified near La Pintada in the hills north of the El Caño site by Mayo et al. (2007). Four of these excavations show evidence of fire-setting for rock excavation which results in characteristic smooth, curved walls (Figure 5), as well as hammered excavations in niches. Stone mining tools were found in one cavern or "mine" at Cerro Cebollal (LP-134) comprising two large hammers, three fragments of grooved hammers which would have had wooden hafts secured to the medial grooves, two mortars and a pestle to 
crush rock (Mayo et al., 2007). The hammers are similar to those described from Mexico and Chile (Craddock et al., 2002; La Niece, 1998; Rovira, 1994). The Cerro Cebollal rockshelter was first occupied during the Early Ceramic A period at 3,000-800 BCE, based on Monagrillo-style ceramics, and again during the Late Ceramic A to $\mathrm{C}$ period at 700-1,300 $\mathrm{CE}$ (700-1,550 $\mathrm{CE}$ in the chronology of Cooke, 2011), based on Conte and Cortezo-Mendoza style ceramics in the stratum which contained the mining artefacts (Sánchez Hérrera, 2007). The mining activity is related to the Conte-style pottery of the Late Ceramic A period of 700-850 CE (Sánchez Hérrera, 2007; 700-1,000 CE in chronology of Cooke, 2011). From a geological examination of Cerro Cebollal by the author, the excavations were made along the low angle contact of a rhyolitic lava with an underlying ash tuff, with weak argillic alteration to quartz, clay and pyrite along the contact and in fractures. The "mine" may have exploited gold, or jarosite for pigment, formed by the oxidation of pyrite, or agate veinlets which are abundant nearby, although none were observed in the mine itself.

An unusual find of a cache of 12 stones was excavated from a preceramic rockshelter at Casita de Piedra near Boquete (Chiriqui), dated to between 4,800-4,000 cal. BP in the Late Preceramic period (Dickau et al., 2013). The stones include quartz crystals, pyrite, chalcedony, bladed quartz with jarosite, and a modified dacite cyl-

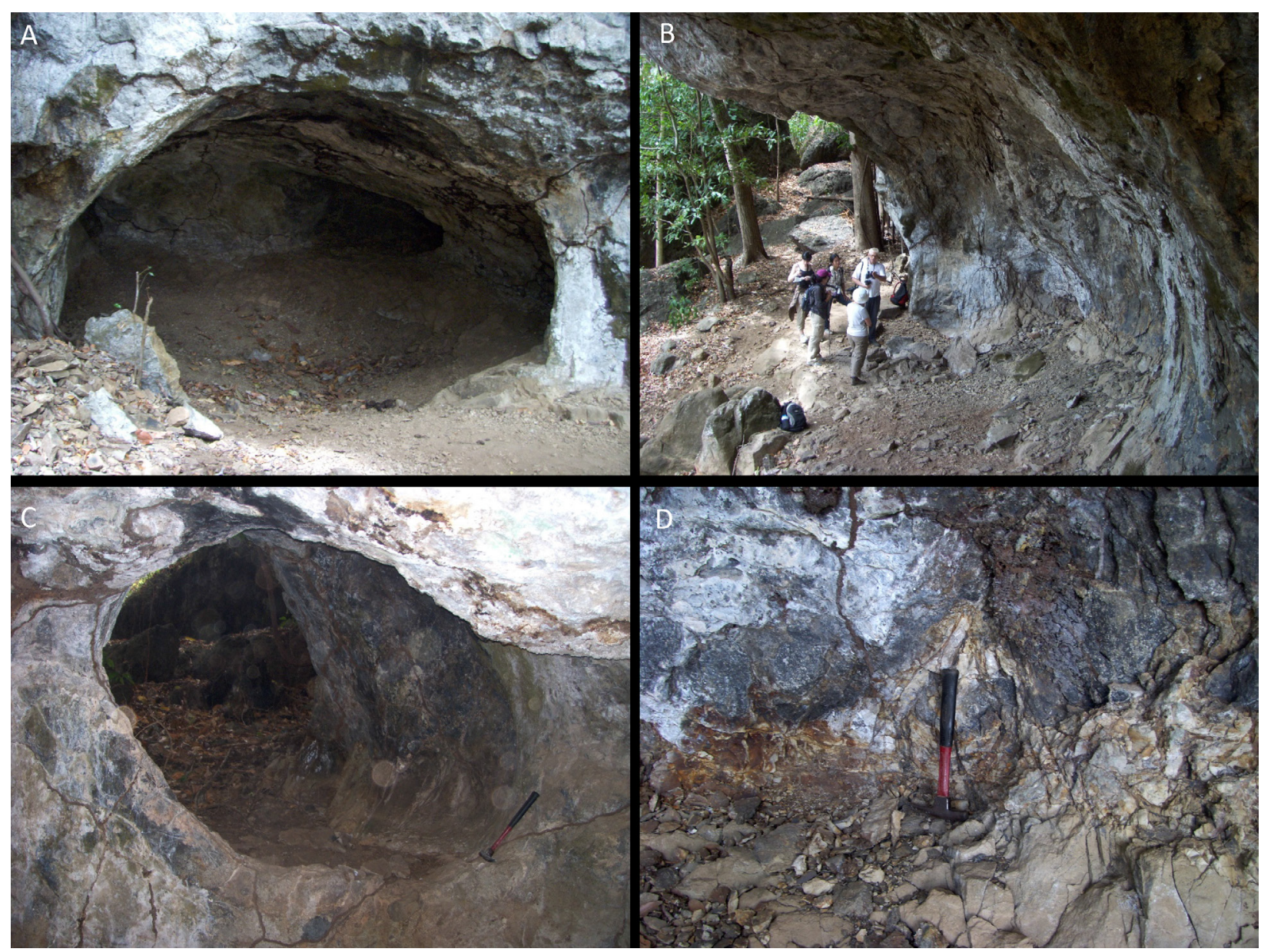

Figure 5 A possible pre-Columbian mine working and rockshelter at Cerro Cebollal (site CR-134) near La Pintada (Mayo et al., 2007; Sánchez Hérrera, 2007). Stone mining hammers, two mortars and a pestle were excavated here associated with Conte-style ceramics of the period 700-1000 CE. The smooth, curved walls may be the result of fire setting for excavation. The excavations are along the contact of a rhyolite lava and underlying tuff, with weak argillic alteration to quartz, clay, pyrite and jarosite along the contact and in fractures (D). The mine may have exploited gold, jarosite for pigment, or agate. (Photographs by Stewart Redwood, 31 March 2009). 
inder. Remarkably, most of the specimens are of rocks, veins and minerals that are commonly associated with epithermal- and porphyry-style mineralization. However, the site pre-dates gold mining in the isthmus by about three millenia. The collector certainly had a geologist's eye for unusual stones; the authors suggested that these stones once belonged to a ritual specialist, such as a healer or shaman.

Finally, three placer gold mine sites and two adits on quartz veins were discovered at Petaquilla (Cobre Panama) in the Coclé goldfield by Griggs (1998). They are described below in the Spanish colonial period.

\subsection{GEOGHEMICAL GOMPOSITION OF GOLD ARTEFACTS}

The only archaeological site where a systematic study has been made of the composition of gold objects is Sitio Conte, where 41 spectroscopic analyses and 45 qualitative analyses were made for $\mathrm{Au}, \mathrm{Ag}$ and Cu by Samuel Lothrop of the Peabody Museum at Harvard University, Cambridge, Mas- sachusetts in the 1930s (Lothrop, 1937). Lothrop divided the results into seven groups which were: 1) $\mathrm{Au}-\mathrm{Cu}$ objects with no $\mathrm{Ag}(9.9-76.4 \% \mathrm{Au}, 21.5-$ $79.2 \% \mathrm{Cu}$; 2) $\mathrm{Au}-\mathrm{Cu}$ objects with low $\mathrm{Ag}$ up to 5.0\% (39.6-97.6\% Au, 3.8-57.5\% Cu); 3) Au-Cu objects with high $\mathrm{Ag}$ up to $14.8 \%$ (12.0-99.0\% $\mathrm{Au}, 0.49-80.8 \% \mathrm{Cu})$; 4) Au-Cu objects with high $\mathrm{Ag}$ up to $22.5 \% \mathrm{Ag}(43.7-88.0 \% \mathrm{Au}, 1.0-42.9 \%$ $\mathrm{Cu}$ ) considered to be imported due to the style; 5) Au objects with no $\mathrm{Cu}$; 6) $\mathrm{Au}$ objects with low $\mathrm{Cu}$ up to $4.5 \% \mathrm{Cu}$, which he considered to be an impurity, with a gap from $4.5-11.0 \% \mathrm{Cu}$ above which it was added to make an alloy; 7) Cu objects, with only one manufactured object, a chisel, while the others were a bar, an ingot and a piece of ore. Based on style, all of the objects were considered to be manufactured locally except for one group, which also had a high Ag content, which is typical of Colombia. Lothrop considered the differences in $\mathrm{Ag}$ and $\mathrm{Cu}$ content to be different ore types or sources, as well as recognizing Au-Cu alloys.

More recently, a systematic analytical study was made of all Panamanian gold artefacts in the Smithsonian Museums Collections in Washington

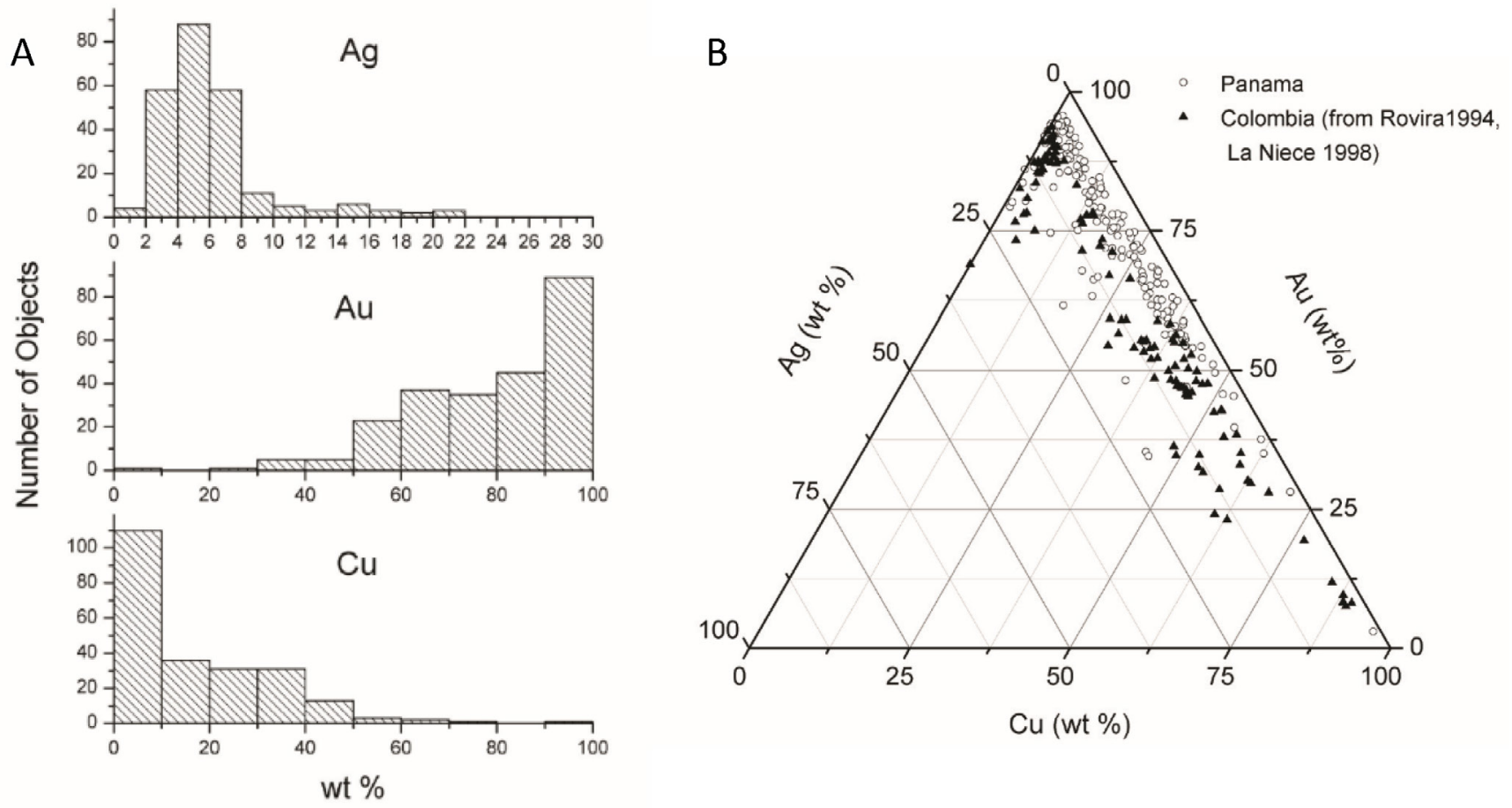

Figure 6 Analyses of $\mathrm{Au}, \mathrm{Ag}$ and $\mathrm{Cu}$ by pXRF of 189 gold objects from Panama in the Smithsonian Museums Collections in Washington. $\mathrm{Au}, \mathrm{Ag}$ and $\mathrm{Cu}$ were normalized to $100 \%$ after removing trace Fe before plotting. A) Histograms of the content of $\mathrm{Au}, \mathrm{Ag}$ and $\mathrm{Cu}$. B) Triangular plot of Au-Ag-Cu compared with Colombian objects. (Harrison and Beaubien, 2010). 
by portable XRF (pXRF) by Harrison and Beaubien (2010). From a total of 309 objects, 91 were rejected for lack of reliable provenance, a further 29 were rejected for unreliable pXRF data such as copper corrosion, to leave analyses of 189 objects for interpretation. All objects contain $\mathrm{Au}$ and $\mathrm{Ag}$, and the majority contain $\mathrm{Cu}$ (Figure 6). Many have trace amounts of $\mathrm{Fe}$, but no other elements were detected. Silver has a median value of $4-6 \%$ and outliers up to $22 \%$. There are two groupings on a $\mathrm{Au}-\mathrm{Ag}$ plot. The majority of objects belong to the first group which has from $0-8 \% \mathrm{Ag}$ in objects of $\mathrm{Au}$ and $\mathrm{Au}-\mathrm{Cu}$ in which $\mathrm{Ag}$ is an impurity. The second group has more than 8\% $\mathrm{Ag}$ and no $\mathrm{Cu}$. There is a clear correlation of higher $\mathrm{Cu}$ in cast objects. Hammered objects have a median of $0-5 \% \mathrm{Cu}$ and a maximum of $40 \% \mathrm{Cu}$, compared with cast objects which have $0-50 \% \mathrm{Cu}$ and some up to $100 \% \mathrm{Cu}$. The addition of copper to gold to form the alloy tumbaga lowers the melting point, increases hardness and improves the casting. The $\mathrm{Au}-\mathrm{Cu}$ alloys can be depletion-gilded to produce a Au-rich surface. The Colombian analyses, in comparison, have a higher average Ag content and a gap between $5-25 \% \mathrm{Cu}$, which is strong evidence that the majority of gold objects were made locally. The Panamanian Goldwork study was expanded to a total of about 1700 pXRF analyses, and publication of the results is awaited (R. Beaubien, personal communication, 29 May 2020).

From a geological point of view, the Ag content of the objects can be explained by the common natural occurrence of $\mathrm{Ag}$ with native $\mathrm{Au}$ or electrum (defined as a natural $\mathrm{Au}-\mathrm{Ag}$ alloy with more than $20 \% \mathrm{Ag}$ ). The ratio of $\mathrm{Au}: \mathrm{Ag}$ varies between different deposits. Variations of the $\mathrm{Ag}$ content may reflect different sources of ore, as concluded by Lothrop (1937) and as demonstrated by geochemistry more recently in other countries such as Ireland (e.g. Chapman et al., 2006). The low Ag content of most objects in the Smithsonian collection indicates the use of native gold rather than electrum. Copper can also occur as a natural impurity in gold and also indicates different ores. However, the copper objects and Au-Cu alloys clearly show that $\mathrm{Cu}$ was used to make alloys indicating that mining was also carried out for copper. This field of study warrants more investigation and the use of other techniques such as inclusion mineralogy, electron microprobe analyses, X-ray mapping, and isotopes to compare with vein and placer gold with the objective of identifying the sources of the gold (e.g. Chapman et al., 2006; Nocete et al., 2018).

\subsection{VERAGUAS GOLDFIELD}

Christopher Columbus saw ample evidence of for gold mining, goldsmithing and trading as he sailed east along the coast of "Veragua" on his Fourth Voyage in 1502, showing that the Veraguas and Coclé goldfields were in full production (Casas, 1561; Colón, 1571; Jane, 1930: Cedeño, 2002; Cooke et al., 2003). He wrote that "in this land of Veragua I saw greater evidence of gold in the first two days than in Hispaniola in four years" (Jane, 1930; Castillero Reyes, 1950).

At "Cariay" (Puerto Limón, Costa Rica), he was told of the gold mines in the province of "Ciamba" (Indochina, actually Veraguas). At Colón Island in Almirante Bay ("Zerabora", "Carabaro" or "Carambaru", Bocas del Toro), he encountered twenty canoes manned by naked people, some of whom wore gold plates (Figure 4B) and a gold eagle. He was to see many more people wearing gold plates. After sailing to "Aburema" (Chiriqui Lagoon), he sailed east to "Guaiga" (Río Chiriqui?), where he traded 16 gold plates, the Río "Cateva" or "Catiba", where he traded another 19 gold plates, "Cobrara" (Río Calovébora?), Veragua and "Cubiga" (Río Coclé del Norte?). Between "Guaiga" and "Cubiga" there were five "towns of great trade" or "towns where he did great trade" (he uses the word rescate which refers to gold trade) including "Veragua" where he was told they got their gold and made the plates. He recorded the native name as "Veragua", which was probably derived from Verdes Aguas (green water), although this is Spanish and not indigenous, and the name was applied to the whole province. 
After sailing to east to "Bel Puerto" (Portobello), "Puerto de Bastimientos" (Nombre de Dios) and Retrete, he returned west in January 1503 and anchored his three ships in the mouth of the Río "Yebra" (Belén), where he established the first European settlement on the mainland of the Americas, Santa María de Belén. Columbus sent his brother Bartholomew to visit a native gold mine in Veraguas, which he described in his Letter of the Fourth Voyage (Jane, 1930): "On the sixth of February, while the rain continued, I sent seventy men ashore into the interior. At five leagues' distance $[\sim 28 \mathrm{~km}$; 1 Spanish league $=5.573 \mathrm{~km}]$, they found many mines. The Indians, who went with them, led them to a very lofty hill and from it showed them the country all round as far as the eye could reach, saying that there was gold everywhere and that towards the west the mines extended for twenty days' journey, and they named the towns and villages, saying where there were more or less of them. Afterwards I learned that the Quibian [chief] who had given these Indians, had commanded them to show distant mines which belonged to one who was his enemy, and that within his own territory a man might collect in ten days as much gold as a child could carry, whenever he wished. I bear with me the Indians, his servants, and witnesses to this. The boats went to the place where he had his village. My brother returned with these people, and all came back with the gold that they had collected in the four hours for which they stayed there. The quantity is great, for none of these men had ever seen mines and most of them had never seen gold; the majority of them were sailors and most of them grumets [lads]."

A more detailed account is given in his biography by his son, Fernando Colón (Colón, 1571), and Bartholomew de las Casas in Historia de las Indias gives a very similar account (Casas, 1561). Based on these accounts, Bartholomew Columbus and Diego Méndez de Segura took 68 men by sea to the Río Veragua, one league $[\sim 5.5 \mathrm{~km}]$ from the Río Belén, and sailed upriver for one and a half leagues $[\sim 8.4 \mathrm{~km}]$ to the village of the cacique Quibián where they stayed for a day. The next day they walked four and a half leagues $[\sim 25 \mathrm{~km}]$ and slept near a river which they crossed 44 times. On the following day they walked another one and a half leagues $[\sim 8.4 \mathrm{~km}]$ to the mines where, "within two hours of arrival, each one had collected gold from among the roots of the trees, which reached to the sky". Afterwards they learned that the mines belonged to the enemy chieftan Urirá and were not those of Veragua, which were closer.

Diego de Porras, clerk and accountant on the expedition, wrote: "it is 8 leagues $[\sim 45 \mathrm{~km}]$ to the mines; it is difficult mountainous terrain with many rivers, which we crossed 39 times; we found many deep mines that belonged to the same two Indians, about half an state deep $[1.7 \mathrm{~m}]$; they are very skilled at getting the gold out; a group of 75 of us went to the mines and in one day we extracted 2 or 3 castellanos [9.2 to $13.8 \mathrm{~g}$ ] without any kind of tools ... the gold is very fine." (Navarette, 1922, p. 318).

The mines were $\sim 42-45 \mathrm{~km}$ from the mouth of the river and the accounts describe indigenous gold mines in the cordillera in the upper part of the Río Veraguas, which were part of a large goldfield. The description of "gold among the roots of the trees" in mountainous country indicates colluvial gold or weathered vein gold, rather than alluvial gold. Richard Cooke, who visited the area in 1977, suggested that they may have crossed west into the valley of the Río Concepción and that they were actually near to the famous Turlurú mine (Cooke et al., 2003).

The Turlurú mines (also written as Turlurí, Tururú and Tururí), near the later town of Concepción, were documented as being mined by indigenous miners prior to the Spanish conquest of the Veraguas goldfields of 1558-1560 and were already well known to the Spaniards by their reputation (Castillero Calvo, 1967a; Jopling, 1994).

\subsection{GOGLÉ GOLDFIELD}

"Cubiga" (Río Coclé del Norte?), at the east end of the Cocle goldfields, was one of the places visited by Columbus in 1502 as he sailed eastwards along the Veraguas coast, and observed five "towns of great [gold] trade" between "Guaiga" and 
"Cubiga", although he makes no specific mention of gold mining (Casas, 1561; Colón, 1571; Jane, 1930). Spanish documents record that alluvial gold deposits in the Coclé region were mined by indigenous tribes in 1522-1526, and indigenous mining presumably continued until the Spanish conquered the region in 1603-1605 (Castillero Calvo, 1967c, 2004, 2019; Wleklinski, 1969; Jopling, 1994; Arias and Griggs, 2004).

\subsection{NORTHERN DARIEN GOLDFIELD}

The rich placer gold mines on the northern side of the Darien mountains near Santa María la Antigua del Darien on the Río Tanela, which enters the Gulf of Urabá at the mouth of the Río Atrato (part of Panama until 1855, now in Chocó, Colombia), were first described by Vasco Nuñez de Balboa in a letter to the Spanish King of 20 January 1513 (Mena García, 201 1; Blas Aritio, 2012) (Figure 7).
Balboa described the distribution of alluvial gold deposits in some detail: "In this province of Darien there are many very rich mines discovered, there is gold in great quantity, twenty rivers have been discovered and thirty that have gold come out of a mountain range that is up to two leagues $[11 \mathrm{~km}]$ from this Villa, ... This mountain range returns down the coast towards the west; from this Villa to the west by this mountain range no river with gold has been seen, I think there are some ..." After describing exploration for gold along the Río San Juan (Atrato) in present-day Colombia, he went on to describe the provinces to the west (Guna Yala) of Careta, where there were "certain rivers that have gold", Comogre and Pocorosa, where "there are very rich rivers of gold" (Blas Aritio, 2012). It is noteworthy that he described mines only three years after the founding of Santa Maria la Antigua and the inference is that these were indigenous gold mines.

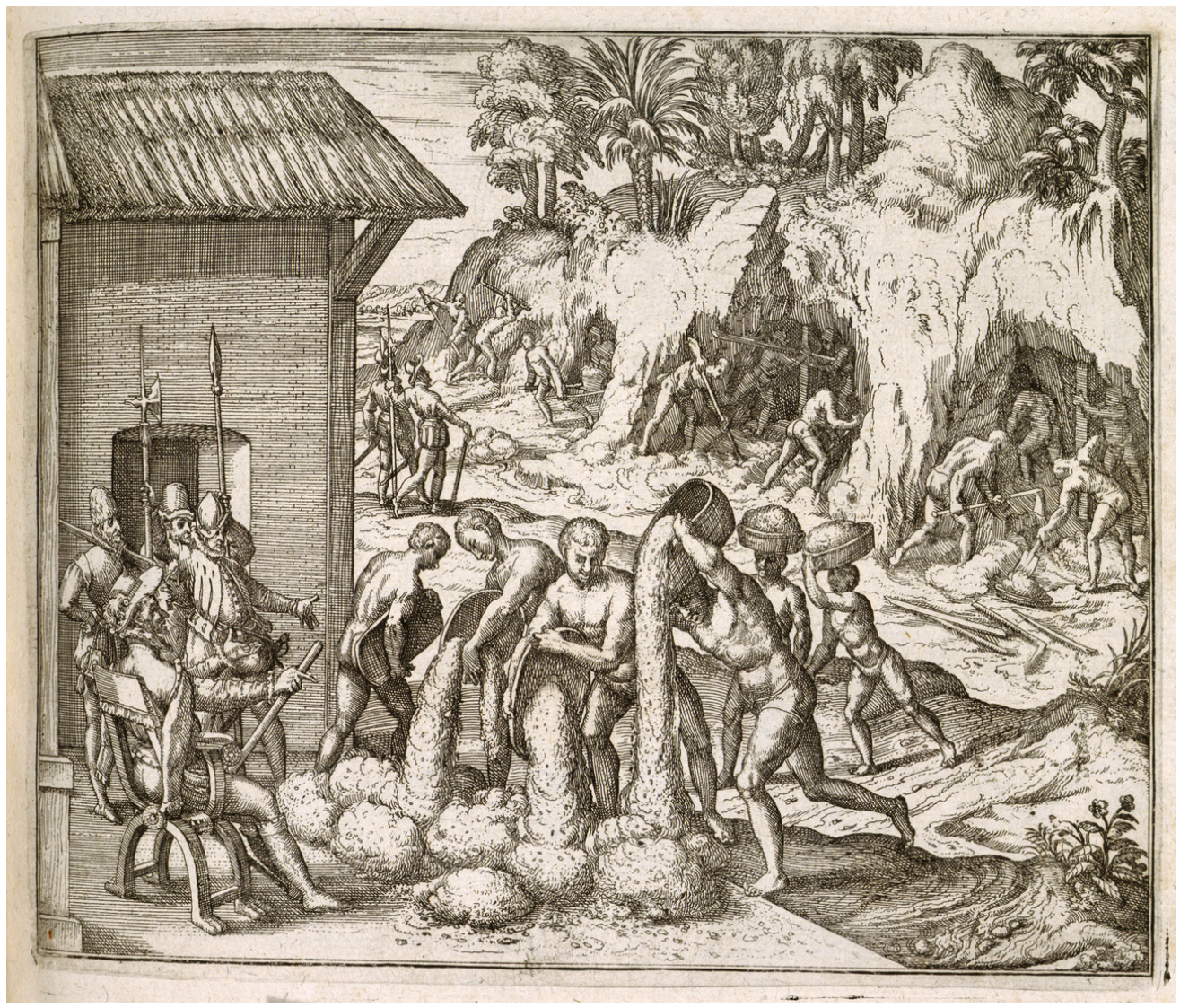

Figure $716^{\text {th }}$ century gold mining in La Española with slaves from Guinea being supervised by Spaniards. (Engraving by Theodor de Bry from Bry (1595). Held and digitized by the British Library and uploaded to Flickr Commons. Reproduced under the Creative Commons CCO 1.0 Universal Public Domain Dedication). 


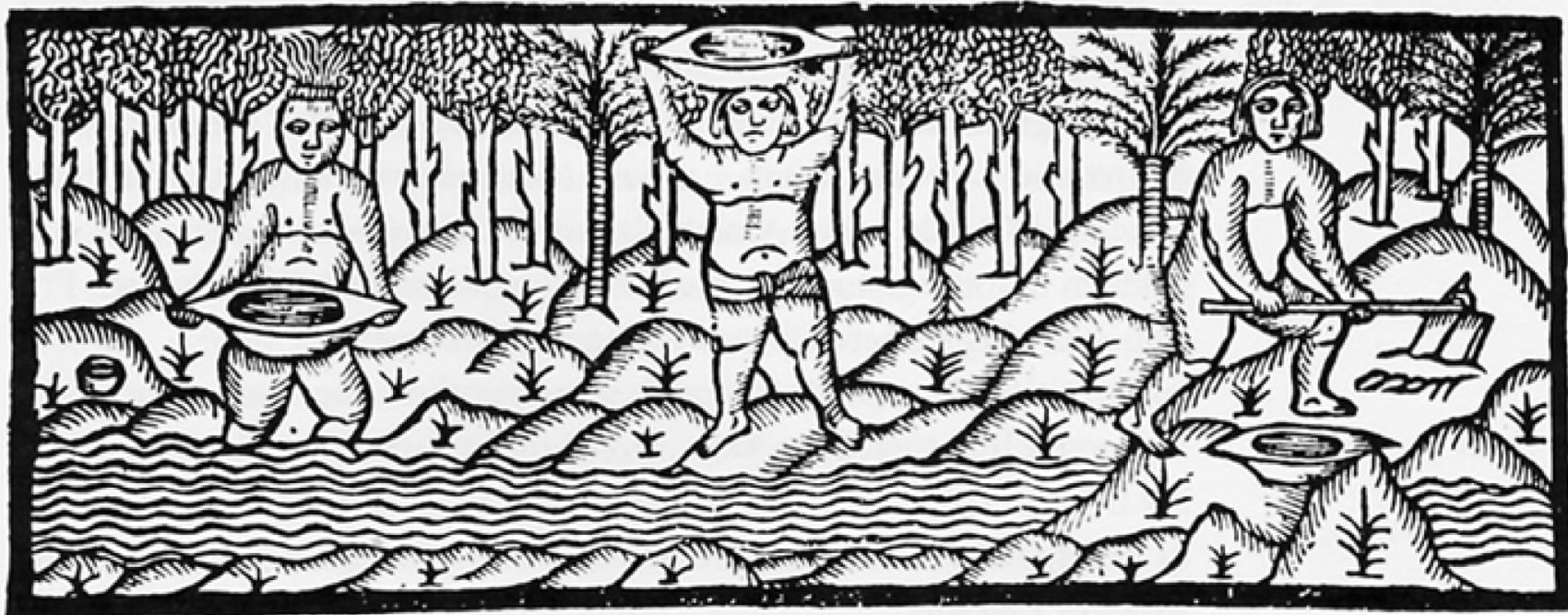

Figure 8 Indians washing gold with wooden bateas or gold pans with handles probably at Santa Maria la Antigua del Darien in Castilla de Oro, early $16^{\text {th }}$ century. (Fernández de Oviedo, 1526. Reproduced under the Creative Commons CC0 1.0 Universal Public Domain Dedication).

Gonzalo Fernández de Oviedo, the King's overseer for gold mining who came to Castilla de Oro with Pedrarias in 1513, described native gold mining methods in Panama in his Natural History of the West Indies (Fernández de Oviedo, 1526). Based on the date, the description is probably of the Santa Maria la Antigua gold mines (Figure 8). "I can affirm as an eyewitness", he wrote, "that all over Castilla del Oro, which is in Tierra Firme, there are many rich gold mines, and that no one could ask me to find a gold mine but that I could locate one within ten leagues". He described gold mining methods on veins and in streams.

"If the lode or vein is located on a savanna or clear place, the Indians clean away everything on the surface of the ground over a square of eight or ten feet; then they dig down a distance of one or two spans. Then without digging deeper they wash all the loose dirt of that area. If they find gold within that area they follow the vein, if not they dig down the same distance and wash the dirt as before. This they continue until gradually, washing all the dirt, they strike solid rock. If they have not discovered gold before reaching the rock, they discontinue mining in that area and move to a new place. But if they do find gold, they continue working at the level they discover it until the vein is exhausted, if they believe the reward will merit such. The length and width of the excavation naturally is determined by the extent of the deposit. Only the discoverer can remove gold from that mine, but adjoining it anyone can strike out a claim for himself." (Fernández de Oviedo, 1526).

The dirt was taken to streams for panning, usually by women (Figure 9). "The washers sit on the bank with their feet up to their knees in the water. They hold the batea by the two handles or ends, they dip up a little water, skillfully pouring it out again, and there enters the pan only the amount of water the Indian wants. Gradually the earth is poured out with the water, and if there is any gold it settles to the bottom of the pan. These pans are concave and about the same size as a barber's basin and almost as deep. After all the earth has been washed out, the gold remains in the bottom of the pan. That gold is placed aside and the pan is refilled to repeat the operation." (Fernández de Oviedo, 1526).

"The second manner of working or mining gold in a stream is as follows. The current of a stream is diverted from its bed and after the bed is dry and water has been bailed out (for 'to bail out' means to exhaust the water in the language of miners) gold may be found between the rocks and in the hollows and cracks of the rocks and in the part that was the main channel or natural bed of 


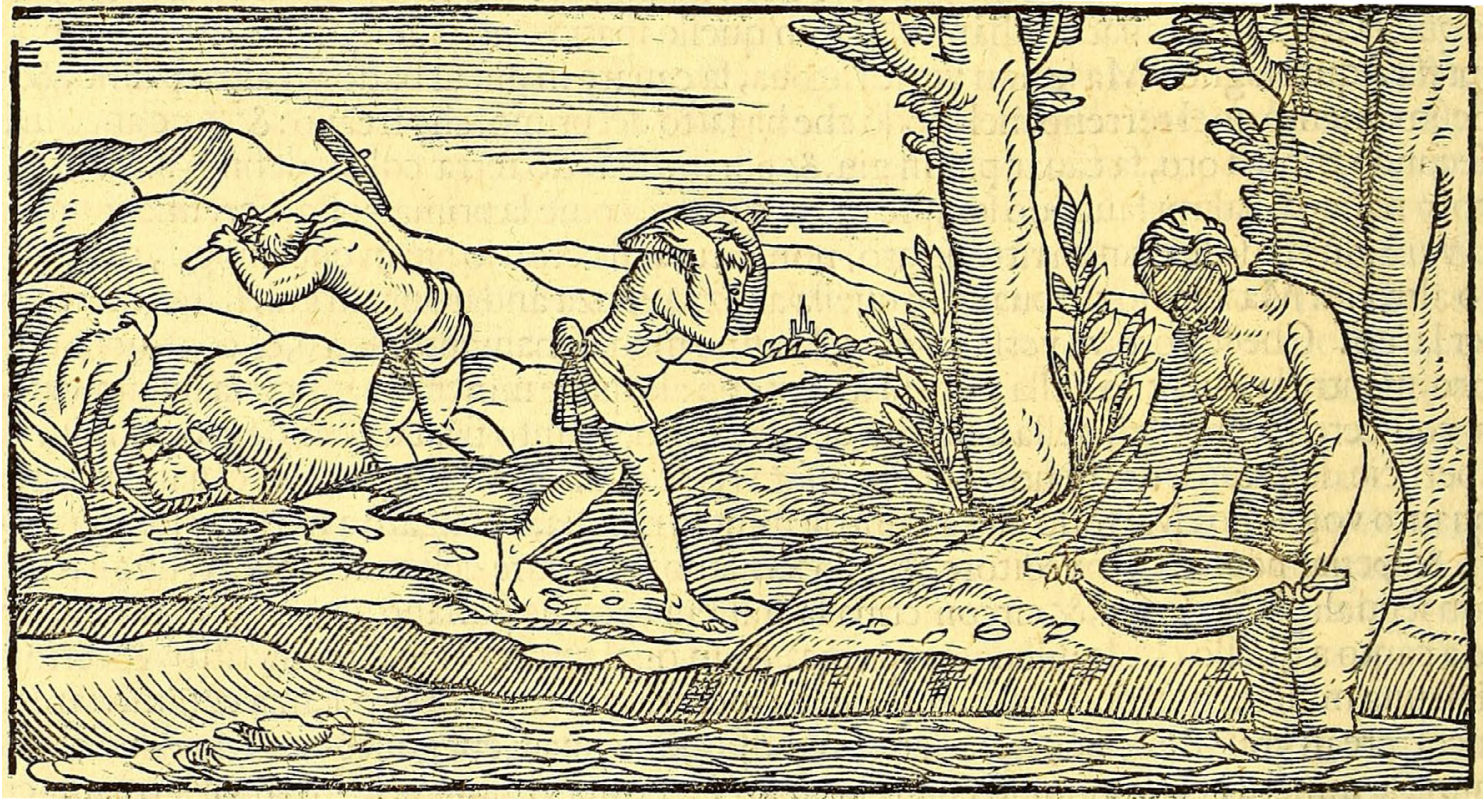

Figure 9 Indians washing gold in wooden bateas probably in La Española, early $16^{\text {th }}$ century. They are working in the same way as described by Fernández de Oviedo (1526) with two men digging auriferous sediment from the river, two men (here only one) carrying the pay-dirt in a batea de servicio, and a woman washing gold in a two-handled batea. (Ramusio, Vol. III, 1556, p. 127; image from 1606 edition, p. 106 at Internet Archive https://archive.org). https://archive.org/details/dellenauigationi03ramu/page/n7/mode/2up

the stream. At times when one of the stream beds is good and rich a large quantity of gold is found in it." (Fernández de Oviedo, 1526).

He then described how the Indians gilded copper. Regarding copper mines, “... large quantities of fine grade copper have been found in many parts of the islands and the mainland of the Indies, and each day more is found. But the people have not cared about it up to now and do not mine it. In other places this copper would be regarded as a great and useful treasure.” (Fernández de Oviedo, 1526).

\subsection{DARIEN GOLDFIELD}

The placer deposits in the Darien goldfield were mined in pre-Columbian times as evidenced by the gold metalwork obtained by Balboa from the chieftains, in particular Tubanamá, when crossing the upper Río Chuqunaque in 1513 on his return from the Pacific discovery (Blas Aritio, 2014). The presence of gold in the rivers was already known to the Spaniards in 1663 before they started mining at El Real in 1665 (Castillero Calvo, 2004, 2019).

\subsection{BATEAS}

The batea or gold pan described above by Fernández de Oviedo (1526) (Figures 8 and 9), and still used today (Figure 10), was probably used in the Caribbean and Mesoamerica by indigenous miners before the Spanish arrival: his account suggests that it was an Indian mining method although it is not specific. The English translation uses the word "tray" but the original Spanish text is "batea". Wooden and ceramic examples have been found in the archaeological record in Mexico dating from the Preclassical Medium Era (the Preclassical Era was 2,000 BCE-250 CE; Langenscheidt, 2009). Linguists debate whether the word batea, a wooden bowl, recorded in the Antilles as early as 1510, is of Taino or Spanish-Arabic origin, for the term was widely used in the New World but was not recorded in Spain until the $18^{\text {th }}$ century (Hernández, 1996; Galeote, 2016); the Real Academia Española favors the latter origin. Agricola (1556, p. 156-157) described bateas in Europe in the $16^{\text {th }}$ century but they were used to carry ore from underground mines; however, the Spanish 
term batea was introduced in the Hoover English translation of Agricola for the original Latin word alueus, or alveus, meaning a trough. Fernández de Oviedo (1526) also described bateas de servicio used to carry pay dirt to the washers. Agricola described the use of small wooden bowls in Lusitania (Portugal and adjacent parts of Spain) to clean up gold from sluice boxes (Agricola, 1556, p. 325). As pointed out by West (1952), it is unlikely that the Lusitanian bowl was introduced to the Antilles without the other technologies such as the sluice box. He suggests that if the batea is of Taino origin, it may have been introduced to other countries such as Mexico and, by inference, Panama from La Española.

\section{The Spanish colonial period mining}

\subsection{OVERVIEW}

Panama was discovered by the Spanish conquistador Rodrigo de Bastidas who sailed west along San Blas (Guna Yala) as far as El Retrete (Escribanos, Santa Isabel) in 1501, and by Christopher Columbus on his Fourth Voyage to the New World in 1502-1503 who sailed east along the coast of Bocas del Toro, Veraguas and Colón as far as Portobello and El Retrete. At Veraguas he obtained gold and visited indigenous gold mines, as described in the previous section. The first European settlements in the mainland of the Americas were established at Santa Maria de Belén in 1503, Nombre de Dios (Colón) in 1510, Santa Maria la Antigua del Darien in 1510 (now Chocó, Colombia; Sarcina, 2017) and Acla (Guna Yala) in 1515, the latter as a port at the start of the trail to the Pacific (Figure 11).

The Spanish colonial period from 1501-1821 was characterized by a major gold rush and exploration boom. Indeed, the new territory of Tierra Firme (the Spanish Main) was also named Castilla de Oro (Golden Castille) after the Kingdom of Castille in Spain and the abundance of gold deposits found on the isthmus. Bartholomew Columbus visited indigenous gold mines in the
River Veraguas in 1503 (Colon, 157 1; Jane, 1930). Vasco Nuñez de Balboa, who discovered the Pacific in 1513, wrote to the Spanish King about the rich gold mines in the rivers near Santa María la Antigua in Darien (Blas Aritio, 2012). In the first years after the conquest (1514-1526), Castilla de Oro produced 13,518 $\mathrm{kg}$ (about 435,000 ounces) of gold obtained in three ways, as recorded by the Royal Treasury of Tierra Firme (Real Hacienda de Tierra Firme): 1) "oro de cabalgadas" which was obtained from raids, 2) "oro de rescates y presentes" which was gold obtained by trade, exchange and presents from the Indians, and 3)
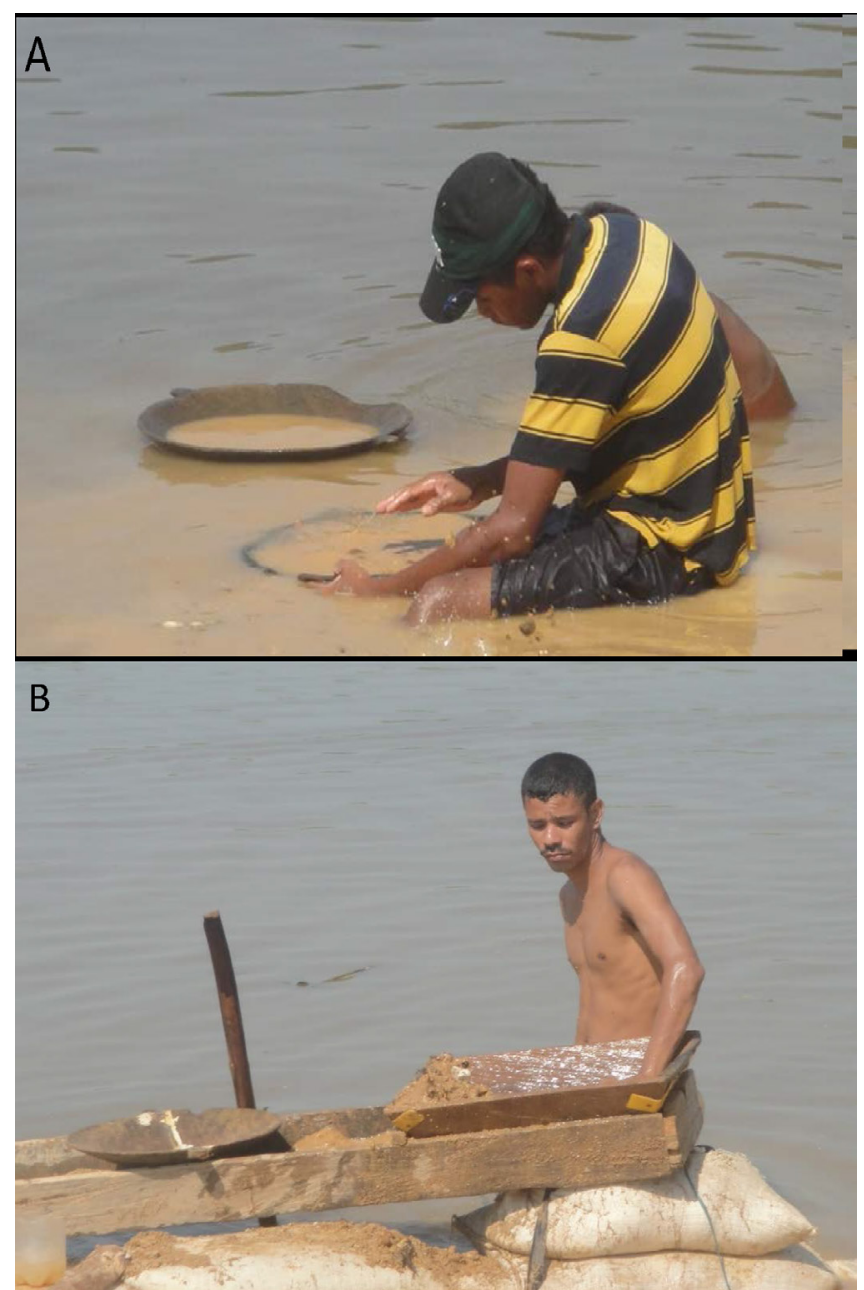

Figure 10 Wooden, two-handled bateas in use today at the Santa Cruz mine on the Rio Magdalena, Bolivar, Colombia. In B) the batea is being used to clean up the concentrate from a sluice. The batea was probably used by indigenous miners in the Caribbean and Mesoamerica before the Spanish arrival. (Photographs by Stewart Redwood, 25 January 2012). 


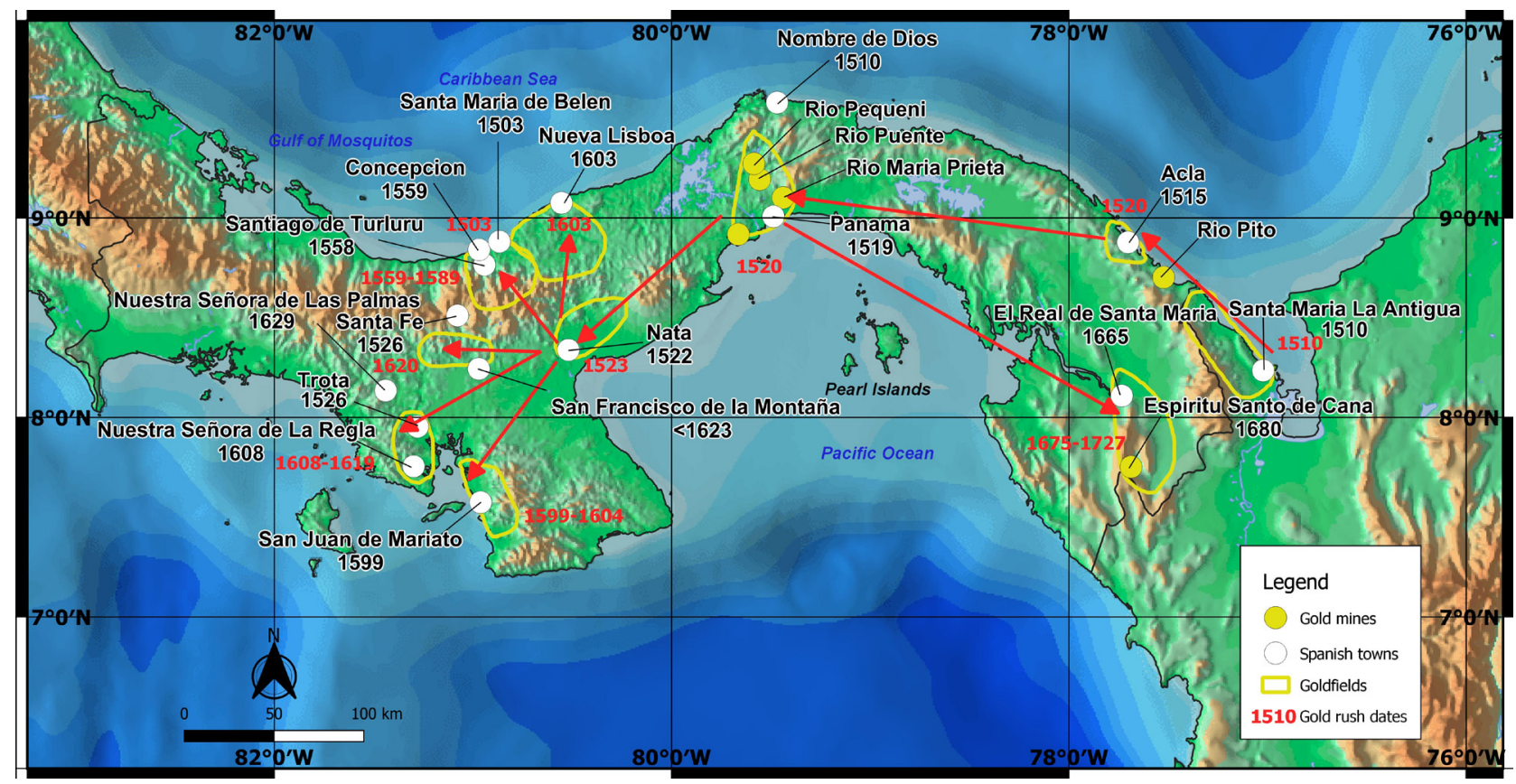

Figure 11 Map of Spanish colonial mining in Panama, 1501-1821. The principal Spanish towns and cities related to mining are shown with their date of foundation. The principal goldfields mined by the Spaniards are shown and some of the important gold deposits; other deposits mentioned in the text are shown on Figure 2. The pattern of gold rushes, conquest and settlement is shown by red arrows and dates. Despite the discovery of the Veraguas goldfield in 1502-03, the initial Spanish gold rush of 1510 was in eastern Darien. Settlement and gold mining moved west to Panama in 1519 and Natá in 1522, and then radiated northwards and westwards throughout Veraguas in several gold rushes over the next century. The final gold rush returned east to the Darien and led to the discovery of the rich Espíritu Santo de Cana gold mine in 1675 (Map by S. Redwood).

"oro de minas" or gold from mines (Castillero Calvo, 2004, 2008, 2019; Mena García, 2011).

Following Balboa's discovery of the South Sea (Pacific Ocean) in 1513, the Darien was abandoned in favor of the new city of Panama on the Pacific in 1519, which was connected to the Caribbean port of Nombre de Dios by the Camino Real (Royal Road) trail (Figure 11). Santa Maria la Antigua was abandoned in 1524, while gold mining continued at Acla until it was abandoned in favor of Concepción in 1559 (Castillero Calvo, 2004, 2019). Alluvial gold was mined at several locations between Nombre de Dios and Panama from 1520 (Jopling, 1994; Mena García, 2011). The town of Natá de los Caballeros (Coclé) was established shortly thereafter in 1522 in the fertile plains of the interior west of Panama City as an agricultural center (Carles, 1969), and gold was discovered there in 1523 (Jopling, 1994; Mena García, 2011). Panama was the base for the expeditions of discovery and conquest of Nicaragua
(1522-1529) and Peru (1526-1532), which slowed the colonization of Panama itself.

From Nata, colonization spread west through the interior of the country (Figure 11). Mining towns were established at Concepción and Turlurú in the Veraguas or Concepción Gold Belt in 1558 and 1559, respectively, which was mined until 1589 . The Azuero and Soná peninsulas were settled in the 1550 s to 1580 s and access to the South Sea was established at the Río Tabarabá (now Río San Pedro) on the Gulf of Montijos near present day Soná. Short lived gold mining camps were founded at San Juan de Mariato (now called Llano de Catival or Mariato) in 1599-1604, and the lost town of Nuestra Señora de la Regla near Montijo in 16081619 (Castillero Calvo, 1967b, 2008). The Coclé gold belt was conquered in 1603-1605 and the town of Nueva Lisboa was founded near the mouth of the Río Coclé del Norte. Mining appears to have been carried out in the Central Veraguas Gold Belt around San Francisco de la Montaña, established 
before 1623, until 1640. Mining declined from 1640-1680 due to a shortage of slaves. Gold mining returned to the Darien in eastern Panama in $\sim 1665$ by way of the Pacific with the founding of El Real de Santa Maria on the Río Tuira to exploit the placer gold deposits, which led upstream to the discovery of the Espíritu Santo de Cana gold mine before 1680 . This was the richest gold mine discovered yet in the Spanish empire. It was mined until 1727, when a collapse of the mine killed several miners, together with Indian uprisings in the region, led to its abandonment for about 170 years (Restrepo, 1886, 1888; Castillero Calvo, 2008). A later discovery was the Capira gold district in 1703, although there were earlier mines there.

\subsection{NORTHERN DARIEN PLAGER GOLDFIELD}

The rich placer gold mines on the northern side of the Darien mountains near Santa María la Antigua del Darien on the Río Tanela, on the Gulf of Uraba at the mouth of the Río Atrato (part of Panama until 1855, now in Chocó, Colombia), were first described by Vasco Nuñez de Balboa in a letter to the Spanish King in 1513 and were mined by the Spaniards from 1514 until 1524 when the town was abandoned (Mena García, 2011; Blas Aritio, 2012). Gold was discovered at Puerto de Misas at Acla in 1520, and the Trepadera mine was recorded in 1524, and gold mining continued until Acla was abandoned in favor of the new gold mines at Concepción in 1559 (Mesa García, 2011; Castillero Calvo, 2004, 2019). Gold was also mined on the Río Pito (Mena García, 2011).

\subsection{DARIEN PLACER GOLDFIELD}

The placer deposits in the Darien goldfield are located in the major rivers west of the Darien Mountains on the Ríos Chuqunaque, Tuquesa, Marraganti, Tuira, Balsas (Tucuti) and Bagre (Marea), and were accessed from the Pacific by way of the Gulf of San Miguel and Ríos Tuira and Chuqunaque (Sheridan, 1926; Oller, 1933,1975; UN, 1972b). The deposits were first worked by the Spaniards in about 1665 when the fort and mining town of El Real de Santa Maria was founded on the Río Tuira, and led upriver to the discovery of the Espíritu Santo de Cana mine before 1680 (Dampier, 1697; Lach-Szyrma, 1909). The famous $17^{\text {th }}$ century mines of the district were Troncoso, Bagre and Tayecúa, in the district of Tucuti (Restrepo, 1886).

Lionel Wafer described Spanish gold mining in a river in the southeastern part of Darien, possibly the Tuira, in 1681, using "little Wooden Dishes" to concentrate the sand, which, after drying, was ground with a mortar, then spread out on paper and a "Load-stone" (magnet) was passed over it to leave "the Gold clean from Ore or Filth". The gold was "bottle[d] up in Gourds or Calabashes." Mining was carried out for only three months a year in the dry season, for the rivers were too deep in the rainy season, and the gold was taken to Santa Maria (Joyce, 1934).

The alluvial gold mines at El Real were raided by the English buccaneer Captain Harris in 1684 as described by William Dampier in 1685 (Dampier, 1697): "About six Leagues from the River's Mouth [Río Santa Maria, or Tuira], on the South-side of it, the Spaniards, about 20 years ago $[\sim 1665$, although it may refer to the date of publication in which case it is 1677], upon their first Discovery of the Gold Mines here, built the Town of Santa Maria. This Town was taken [in 1680] by Capt. Coxon, Capt. Harris and Capt. Sharp at their entrance to the South Seas, it being then newly built. Since that time it has grown considerable. For when Captain Harris, the Nephew of the former, took it, he found in it all sorts of Tradesmen, with a great deal of Flour and Wine, and abundance of Iron Crows and Pickaxes. These were Instruments for the Slaves to work in the Gold Mines, For, besides what Gold and Sand they take up together, they often find great Lumps wedged between the Rocks, as if they naturally grew there. I have seen a Lump as big as a Hen's Egg, brought to Captain Harris (who took 120 pounds there), and he told me that there were Lumps a great deal bigger. But these they were forced to beat in pieces, so that they might divide them. These Lumps are not so solid, but have Crevices and Pores full of Earth and Dust." 
Vein deposits in the Darien were also mined for gold historically. These include the El Pablo vein at La Marea on the Río Marea which was mined in the early $17^{\text {th }}$ century (Lach-Szyrma, 1909; Low, 1931); the Mother Lode veins more than 3 $\mathrm{km}$ long with Spanish mine workings on the Río Marraganti, a major tributary of the Río Tuquesa (Sheridan, 1926); and veins at the San Francisco mine on the Río Tuquesa, which were mined in the early $20^{\text {th }}$ century (Oller, 1933).

\subsection{PANAMA GOLDFIELDS}

Alluvial gold was mined at several locations between Nombre de Dios and Panama from 1520 (Chilibre district). These were on or near the Camino Real trail: gold mines are recorded on the Río Puente, with the Puente Admirable or La Puente natural bridge, a tributary of the Río Chagres; at Pequení (now under Lago Alajuela); and at the Gracias a Dios gold district, an unidentified locality between the two cities (Jopling, 1994; Mena García, 2011). New mines were discovered on the Río Pequeni in 1583, where mining continued until the $17^{\text {th }}$ century. Gold was also mined at Emperador (Ancón district) in the Spanish era, as described below; and gold was mined in the $17^{\text {th }}$ century at Quebrada San Bartolomé (unidentified), two leagues $(11 \mathrm{~km})$ from Panama; in the Río María Prieta, a tributary of the Río Juan Díaz, Pedregal; near Chagres; ; at Vaca de Monte (Arraijan?); and at Bique, Cerro Cabra, Arraijan (Castillero Calvo, 2019). Gold was mined at Bique periodically, most recently by locals in the 1940s to 1960s (Reverte Coma, 1961; Gutiérrez, 1999).

\subsection{SANTA RITA Au DEPOSIT}

Gold mineralization occurs in quartz-sulfide veinlets on Cerro Santa Rita east of the town of Sabanitas (Colón Province), with alluvial gold in the streams that drain the hill. These gave rise to the name of Bahia de las Minas (Mines Bay) on the Caribbean coast to the north. Woodring (1957) described evidence for three periods of mining: remnants of large stone mortars from "indige- nous operations"; caved adits associated with a French boiler with the date 1883; and "modern adits". The mines were worked in the Spanish period and the earliest reference is 1751 (Webster, 1984). Grinding stones found at the site may be evidence of pre-Columbian mining, as suggested by Woodring (1957), or may be from the Spanish period (Figure 12).

\subsection{NATÁ-PENONOMÉ GOLDFIELDS}

Gold was discovered near Natá in 1523 shortly after the town was founded (Jopling, 1994; Mena García, 2011). Gold mines at Chucú and the Río Turbez near Natá, and Quebrada de Cervantes four leagues $(22 \mathrm{~km})$ from Natá were mentioned in a report by Juan de Valencia in 1669 (Castillero Calvo, 2019). Gold was also mined near San Miguel de Toabré, north of Penonomé, where 18 quintales $(28,800$ oz.) of gold was extracted; the Indians mined 20,000 castellanos (2,958 oz.) of gold per year, and the Spaniards 6,000 castellanos (887 oz.) (Castillero Calvo, 2019). Several gold mines were worked in the Río Santa Elena in Coclé between 1606-1631 (Castillero Calvo, 2019). Alluvial gold was mined by hydraulic methods on the upper part of the Río Grande de Coclé in the 1930s (Lothrop, 1937).

\subsection{VERAGUAS (CONGEPGIÓN) GOLDFIELD}

Placer gold deposits occur on the Ríos Santiago, Concepción, Veraguas and Belén in the foothills and the Caribbean lowlands on the northern side of the Central Cordillera of the Veraguas gold district, also known as the Concepción or Santa Fé district. The gold is derived from epithermal veins which were also mined, the best known being the Margaja mine. Following Columbus' visit to the Veraguas gold mines in 1503 (Colón, 1571; Jane, 1930), the area was not colonized or mined by the Spaniards for another half century. Several unsuccessful expeditions were made, the first expedition to reach the Turlurú mine being by Diego de Albítez in the late 1520s (Castillero Calvo, 1967a). 


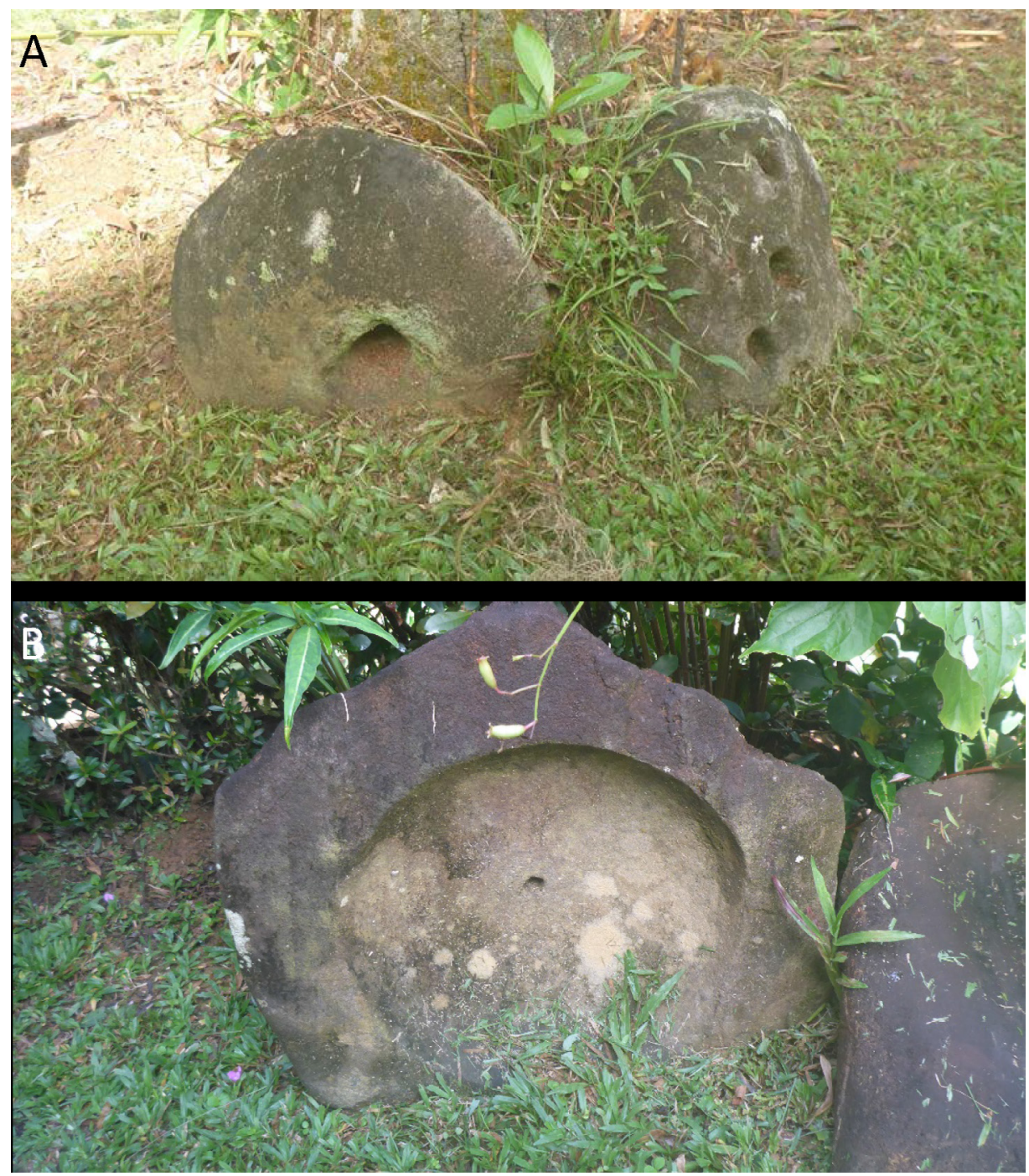

Figure 12 Grinding stones or stone mills at the Santa Rita gold mine, Sabanitas, Colón. A) The grinding stones have three holes in the top and one in the bottom. The central hole went through the stone and was to feed ore to the grinding bowl. The lateral holes on top were for two poles to rotate and rock the stone in the concave mortar (B). The stone mills may either be from the pre-Columbian or Spanish colonial periods. (Thanks to Ida Herrera for showing me the stones on her property. Photographs Stewart Redwood, February 2020).

The district was an important Spanish gold producer in the mid to late $16^{\text {th }}$ century following the conquest of Veraguas in 1558-1560 by Francisco Vásquez. He established the towns of Santa Fé in 1558, Santiago de Turlurú (or Turlurí) in 1558 at the gold mines between the Ríos Santiago and Barrera, and Real de Minas Concepción in 1559 at the river mouth (Jopling, 1994; Castillero Calvo, 1967a, 1967b, 2008; Wleklinski, 1969). The Concepción district was mined from 1559-1589 with more than 100 Spanish miners and 2,000 slaves and produced a total of 2,014,324 pesos of gold (about $8,680 \mathrm{~kg}$ or 279,000 ounces; 1 peso weighed $4.31 \mathrm{~g}$ ) in 30 years from alluvial and quartz vein deposits, with peak annual production of 140,617 pesos (606 kg, 19,485 oz.) in 1576 (Castillero Calvo, 1967b). The Concepción mines suffered from attacks by pirates and Coclé Indians, and were abandoned in 1589 when the miners flocked to newly discovered gold mines at Zaragoza on the Río Nechi in Antioquia, Nueva Granada (West, 1952; Castillero Calvo, 2004, 2019).

The town of La Trinidad was founded for gold mining on the Río Belén in 1566 (Castillero Calvo, 
1967b). Mining was carried out again at Concepción in 1629-1640, and continued intermittently from the $17^{\text {th }}$ century to this day. In 1667 , two pirates, Moisés Vauclein and Pedro el Picardo, sacked the town of Veraguas (Concepción) and plundered 7 or 8 pounds $(3.5-4.0 \mathrm{~kg}$ ) of gold (Restrepo, 1886).

The Veraguas gold district was evaluated by United Nations in 1965-1969 as part of the Azuero Mining Project (Wleklinski, 1969). Part of the production in the Veraguas gold belt was from the Cocuyo-Guinea deep-lead placer gold deposit which was an alluvial deposit in an old valley covered by a young basalt flow $8-10 \mathrm{~m}$ thick and about $40 \mathrm{~m}$ above the present valley on the ridge between the Ríos Santiago and Barrera. The deposit was mined in 1559-1589 by means of over 400 tunnels dug below the basalt. Evaluation of the deposit by the UN estimated that $10-20 \%$ of the gravel was mined over 30 years and would have yielded 100-1000 $\mathrm{kg}$ of gold (3,215-32,150 ounces) (Wleklinski, 1969).

\subsection{SOUTHERN VERAGUAS GOLDFIELDS}

A copper-gold mine was described at the town of Trota in the southeastern part of the Soná peninsula as early as 1560 (Jopling, 1994, p. 10). Trota was a chiefdom that was conquered in $\sim 1526$ and had a Spanish port located on the Río Caté on the Gulf of Montijo. The Spanish town of La Filipina (1571-1589) was later established nearby. The 1560 report on The Mines of Veragua stated that: "That port needs to be repopulated because in that province there are Indians and gold mines, both low purity gold with copper and fine gold" (Jopling, 1994, p. 10).

Small placer gold deposits occur in several rivers in the western Azuero and Soná peninsulas of southern Veraguas and were exploited by the Spaniards in two minor gold rushes in the $16^{\text {th }}-17^{\text {th }}$ century as the region was settled (Figure 11) (Castillero Calvo, 1967c, 2004, 2008, 2019). The first gold rush took place in 1599-1604 between the Río Tebario and Río Quebro in the hills of Guanete (Azuero Massif), around the mining town of San Juan de Meriato (or Mariato, now called Llano de
Catival or Mariato), in a district about $30 \mathrm{~km}$ long on the western side of the Azuero peninsula. It produced a total of 32,000 pesos of gold (137.9 $\mathrm{kg}, 4,434$ oz.). Alluvial gold in the Río Torio in this district was worked again in 1638 and 1772.

The second new placer gold mining discovery was on the Río Tabarabá (now called the Río San Pablo) near Montijo in 1608-1619, where the lost town of Nuestra Señora de la Regla was founded (Castillero Calvo, 1967c, 2004, 2008, 2019).

Nuestra Señora de las Palmas was founded by 1629 by miners from Concepción who mined for gold nearby. Gold was also found on a hill near Soná in the $17^{\text {th }}$ century (Castillero Calvo, 2004, 2019) which was probably colluvial gold related to the Soná porphyry gold deposit.

\subsection{GOGLÉ PLAGER GOLDFIELD}

The auriferous rivers of the Cocle district are the Ríos Chiquero, Petaquilla, Caimito, San Juan, Toabré and Coclé del Norte in the Donoso District of Colón Province (Figures 2, 11; Griggs, 2005). Spanish documents record that alluvial gold deposits in the Coclé region were mined by indigenous tribes in 1522-1526. The Spanish Governor of Veraguas, Juan López de Sequeira, conquered the region in 1603-1605 and founded the short-lived mining town of Nueva Lisboa near the mouth of the Río Coclé del Norte, although its exact location is now unknown. The town was later moved to placer gold mines on the Río Belén and finally to the mouth of the Belén, before being abandoned. Gold production was 101,212 pesos (436 kg, 14,024 ounces) between 1604-1607 (Castillero Calvo, 1967c, 2004, 2019; Wleklinski, 1969; Jopling, 1994; Arias and Griggs, 2004). There were also historical Spanish gold mines on veins at San Antonio and Santa Lucia on the Río Coclé del Norte (Griggs, 2005). Another Spanish gold rush was centered on the mining town of La Palma which was founded in 1619 on the Río Palmilla, a tributary of the Río Chiquero (Castillero Calvo, 1967c, 2008).

Three archaeological sites of placer mining and four small mines on quartz veins were identified in the Petaquilla area of the Coclé goldfield 
by Griggs (1998, 2005). He interpreted them to be of colonial age although no cultural artefacts were found to determine whether they are pre-Columbian or colonial. Site DO-6 is $\sim 15 \mathrm{~km}$ south of the Caribbean coast on a tributary stream of the Río Petaquilla, and about $1.5 \mathrm{~km}$ NW of the Colina copper deposit. It consists of a level mound of cobbles and pebbles with an area of $9 \mathrm{~m}$ by $6 \mathrm{~m}$, with irregular sides, and the walls are formed of neatly stacked cobbles $\sim 1 \mathrm{~m}$ high. Site DO-7 is located close to the Río Petaquilla, which is about $400 \mathrm{~m}$ south of DO-6, and consists of mounds of cobbles and pebbles that are well-stacked in the two largest mounds, and a trench. The mounds are consistent with the placer mining method of ground sluicing, as described by West (1952). A ditch or sluice channel was dug along the base of the gravel terrace, the gold-bearing sand and gravel were dumped in the sluice where the gold was concentrated by flowing water, and then cleaned up with a batea or gold pan. The cobbles were stacked on the other side and the gravel terrace face was excavated or pushed back in repeated operations, and the waste rock mound grew, with a retaining wall to prevent collapse. According to West, ground sluicing was the main placer mining method in colonial times. He considered that it was developed by prehistoric indigenous miners in Colombia and was later spread by Spanish miners to other parts of the Americas. It was also an ancient mining technique in the Old World.

Site DO-28 is located $22 \mathrm{~km}$ south of the coast on Quebrada Daniel, a tributary of the Río Botija, just north of the Botija copper deposit. There are five trenches parallel to the stream and six circular pits on either side of the stream in an area of about $90 \mathrm{~m}$ by $55 \mathrm{~m}$ (Griggs, 1998). The mining technique was probably pit placering, which was used in Colombia from early colonial times, and may have been introduced from Hispaniola (West, 1952).

Two small adits $3.5 \mathrm{~m}$ and $1.7 \mathrm{~m}$ long were found above the Río Mestizo (site DO-14, Griggs, 1998) near the Molejon gold deposit. The first adit is on epithermal veins with drusy quartz, and they were probably dug to prospect for of mine gold.
Two historical Spanish mines on quartz-gold veins were found at San Antonio (site LP-21) and Santa Lucia (LP-25) on the Río Coclé del Norte and were probably operated until the $18^{\text {th }}$ century (Griggs, 2005). Both sites have milling stones and deep pits, with an adit and a small dam at Santa Lucia. The San Antonio mine was sacked by Miskito Indian raiders from Nicaragua in 1765 (Castillero Calvo, 1994; Griggs, 2005).

\subsection{GENTRAL VERAGUAS GOLD BELT}

The Central Veraguas Gold Belt is a belt of epithermal gold vein deposits covering an area of about $40 \mathrm{~km} \mathrm{E-W}$ by $20 \mathrm{~km}$ wide (Wleklinski, 1969; Nelson, 2001; Folk, 2004b). Numerous epithermal gold deposits were mined after the town of San Francisco de la Montaña was founded as a mining settlement before 1623 (Carles, 1969) but the history of the mines is poorly known. The mines do not appear to have been worked in the pre-Columbian era or in the $16^{\text {th }}$ century as they are not mentioned in early Spanish accounts. Mining was carried out in the Central Veraguas Gold Belt until 1640. One of the oldest mines is Los Hatillos near San Francisco. The San Pedrito gold mine, located between the Remance and Santa Rosa gold mines, has open-cut workings considered to be of early Spanish or pre-Columbian age (Wleklinski, 1969). New deposits were discovered in the belt in the mid-18 $8^{\text {th }}$ century at Aguacatal (or Aguacate), abandoned in 1777, and Remance (Castillero Calvo, 2004, 2008, 2019). San Francisco Javier de Cañazas (Cañazas) was founded in 1767, which suggests the date of discovery of the nearby Santa Rosa and Cerro Las Minas gold mines, and Calobre was refounded shortly after, having been first established in the mid- $16^{\text {th }}$ century.

\subsection{ESPÍRITU SANTA DE GANA GOLD MINE}

The Espíritu Santo gold mine at Cana, known originally as Santa Cruz de Cana, was the most important historical gold mine in Panama. It is located close to the Colombian border in the Pirre 
Table 2. The history of the Espíritu Santo de Cana gold mine.

\begin{tabular}{|c|c|}
\hline Year & Owners and Events \\
\hline 1665 & El Real de Santa Maria founded, placer gold mined on Rio Tucuti. \\
\hline$\sim 1675$ & Espiritu Santo de Cana discovered and mined by Spaniards. \\
\hline 1680 & $\begin{array}{l}\text { Captain Sharpe, an English buccaneer, raided Santa Maria for gold that was brought } \\
\text { from Cana, which was already in full operation. }\end{array}$ \\
\hline 1684 & Captain Harris, an English buccaneer, raided the El Real mine. \\
\hline 1702 & $\begin{array}{l}\text { Nathaniel Davis, an English buccaneer, raided the Espiritu Santo mine. Further pirate } \\
\text { raids in } 1712,1724 \text {. }\end{array}$ \\
\hline 1727 & Espiritu Santo de Cana mine closed due to collapse and Indian uprising. \\
\hline $1727-1880$ & No activity. \\
\hline 1877 & $\begin{array}{l}\text { Lucien Napoleon Bonaparte Wyse, the French engineer who obtained the Wyse } \\
\text { Concession for the French canal in } 1878 \text {, visited the mine and claimed it for the } \\
\text { company. }\end{array}$ \\
\hline 1880 & The Wells American Company tried to reopen the mine. \\
\hline 1883 & Staked by Compañía Minera del Darien, Bogota. \\
\hline 1887 & Sold to the Darien Gold Mining Company Ltd., Manchester. \\
\hline 1887-1892 & Mined the El Rey Mine. Installed a 20-stamp mill. \\
\hline 1893-1907 & Espiritu Santo Mine rediscovered and mined profitably. \\
\hline 1907 & The Darien Gold Mining Company went bankrupt. \\
\hline 1907 & $\begin{array}{l}\text { New company with same name formed, The Darien Gold Mining Company Ltd., and } \\
\text { mostly French capital. }\end{array}$ \\
\hline 1907 & $50 \mathrm{~km}$-long, narrow gauge $(0.6 \mathrm{~m})$ railway built from Boca de Cupe to mine. \\
\hline 1912 & Mining stopped. \\
\hline 1914-1926 & Acquired by creditor Don Tomas Arias and mined. \\
\hline 1927-1932 & $\begin{array}{l}\text { Explored by The Panama Corporation Ltd. Evaluated bulk mineable target on Cerro } \\
\text { San Jose. }\end{array}$ \\
\hline 1932-1964 & No activity. \\
\hline 1964-1966 & Mintrade Group (Mauricio Hochschild company) explored. \\
\hline $1970 \mathrm{~s}$ & Texas Gulf Western Inc. exploration. Drilled 16 holes. \\
\hline $1970 \mathrm{~s}$ & St. Joe Minerals exploration. \\
\hline 1980 & Sociedad de lnversiones IXTAPA S.A. awarded the concession. \\
\hline 1985-1988 & $\begin{array}{l}\text { Optioned to Freeport Exploration Company (Freeport de Panama). Drilled 4,600 } \mathrm{m} \text { in } \\
40 \text { holes at North Mine. }\end{array}$ \\
\hline 1992 & Evaluated by Gold Fields of South Africa. 1,200-hole soil auguring program. \\
\hline 1993 & IXTAPA bought by NGO ANCON, Panama. \\
\hline 1995-1997 & ANCON optioned project to Link Mineral Ventures Ltd., Toronto to earn $80 \%$. \\
\hline 1996 & Mining banned in the Darien National Park. \\
\hline
\end{tabular}

Massif. The total gold endowment (production plus resources) is estimated to be about $59 \mathrm{t}$ (1.9 Moz), much at bonanza grades of over $1,000 \mathrm{~g} / \mathrm{t}$ (Restrepo, 1888; Redwood, 2020c).

The placer deposits in the Tucuti district, part of the Darien goldfields, were first worked in about 1665 when the fort and mining town of El Real de Santa Maria was founded on the Río Tuira, 40 $\mathrm{km}$ north of Cana. The Espíritu Santo mine was discovered by Capitán Antonio de Landeche and was worked by the Spaniards from before 1680 to 1727. Santa Maria was captured by English pirates in 1680 and 1684, and the Cana mine was raided by pirates in 1702, 1712 and 1724 (Restrepo, 1886; Joyce, 1934). The first reference to the mine was in 1680 when English buccaneers under Captain Bartholomew Sharpe raided Santa Maria to obtain the gold that was brought down from the Cana mine. Basil Ringrose wrote (Exquemelin, 1685; Esquemeling, 1911): "This golden Treasure 
cometh down another branch of this River unto Santa Maria, from the neighboring Mountains, where are thought to be the richest Mines of the Indies, or, at least, of all these parts of the Western World. ... But as bad a place as it was, our fortune was much worse. For we came only three days too late, or else we had met with three hundred weight of Gold, which was carried thence to Panama in a Bark [boat], that is sent from thence twice or thrice every year, to fetch what Gold is brought to Santa Maria from the Mountains."

English pirates raided the Cana mine in 1702, 1712 and 1724. Nathaniel Davis reported that the town of Cana, which they burned in 1702, had about 900 houses and one church. His account was the first description of the mine (Davis, 1702): "... the Mine is on the side of a great Hill, above Thirty Yards [27.4 m] deep, and several Caves run into the Hill farther than anyone would venture to go; the Oare they dig out of it is a sort of a mixture of Rock, which after it is dug out of the Mine is brought to the Mill, which grinds it small, then 'tis washed, made up into the form of Bricks and lodged in Houses built at the Mine for that purpose, over which a Guard is set, with a Captain and a Governour to see that the King is not cheated. After it has lain some short time in those Houses, then it is washed a second time, and so cleared of the Dross or some rocky Part wherewith it's intermixed till there remains pure Gold. They make a great quantity of Gold every Day they work; we made five pound weight and nine Ounces [about $2.8 \mathrm{~kg}$ ] in less than a Day." The pirates extracted a total of $49 \mathrm{lbs} 9 \mathrm{oz}$. (about 24.6 $\mathrm{kg}$ ) of gold in four days.

The nineteenth century rediscovery of Espíritu Santo de Cana showed that the Spanish mine had a shaft and four levels to a depth of $60 \mathrm{~m}$, and it was reported to have employed 200 miners (Restrepo, 1886, 1888; Woakes, 1895, 1899).

Another member of the 1702 expedition was Robert Allen, a Scots merchant who deserted from the Scottish Darien colony in 1698, went to Jamaica and then returned to Darien to look for Nicaragua wood, where he survived an Indian massacre and lived with friendly Indians until joining the 1702 raiding party (Alsop, 1986). His report shows the size of the expedition. "Being at length informed by them that nine English Sloops were on that Coast I gott on board of these and found about 600 men of Her Maty's [Majesty's] Subjects that had commissiones from the Governour of Jamaica and were designed on an expedition against Her Maty's Enemies in the Spanish West Indies. I Joyned myself to them and prevailed with 60 Indians to accompany us. 560 of us marcht from ye mouth of the River Choco and took the town and mines of Cana and returned to our sloops in less than a month with good Booty." (Alsop, 1986).

The high gold grade, estimated to have been $0.13 \%$ or 1,330 $\mathrm{g} / \mathrm{t}$ (Restrepo, 1888), made the mine by far the biggest producer in the Americas at the time. By 1712, the Darien province was reported to have a population of 20,000, compared to only 7,000 in Panama City (Castillero Calvo, 2019). Pockets of gold were encountered said to contain $120-600 \mathrm{lbs}(55.2-276.0 \mathrm{~kg}$ or $775-8,874$ ounces) of gold. In 1708, it was reported that the King's royal fifth tax was 82,000 castellanos (377.0 $\mathrm{kg}$ or 12,130 ounces) indicating total production for that year of about $1,866 \mathrm{~kg}$ (60,000 ounces); while other sources say the tax was as high as 100,000 castellanos ( $460.0 \mathrm{~kg}$ or 14,790 ounces) giving total production of $2,300 \mathrm{~kg}$ (74,000 ounces). Some sources gave annual production of more than 1 million pesos of gold (about 1,648 $\mathrm{kg}$ or 52,000 ounces) (Restrepo, 1886, 1888). It is estimated that the mine produced more than 30 million pesos of gold in the Spanish period which is about 48,600 $\operatorname{kg}(1,562,000$ ounces) (Restrepo, 1886, 1888).

The mine was abandoned in 1727 due to the collapse of the shaft resulting in the death of two miners, as well as the indigenous insurrection in the Darien in 1726-1727, which was not pacified until 1778, and the frequent pirate raids.

\subsection{GERRO NEGRO Au-Ag PROSPECT}

The Cerro Negro mine, about $20 \mathrm{~km}$ NW of Chitré (Herrera) is said to have been the first Spanish silver mine in the Americas in the early 
$16^{\text {th }}$ century, and the silver coined at a mint at the town of Natá (Riddell, 1927). However, there was no known mint in Natá and so the veracity of this source is in some doubt.

\subsection{EL GALLO Au-Ag-Pb MINE}

The El Gallo gold mine at Las Minas (Herrera) is described as a $16^{\text {th }}$ century Spanish mine which was mined in a glory hole or open pit about $45 \mathrm{~m}$ in diameter on the hill-top (Riddell, 1927).

\subsection{CAPIRA GOLD DISTRICT}

The Capira gold district in Panama West Province is formed by several epithermal quartz veins over a zone of about $15 \mathrm{~km}$ between San Martin (El Espino) and Cerro Campana. It was mined in pre-Columbian times and is documented in the founding of the town of Natá by the Spaniards in 1522 when the neighboring towns were described as "Chirú and Chame, and Capira (a patrimonial gold settlement) was located in that vicinity" (Castillero Calvo, 1973; Mérida, 1995).

However, there is no other reference to gold mining at Capira until 1703 when gold veins were discovered by the Spaniards. Fray Juan de Arguelles, Bishop of the Cathedral of Panamá, wrote to King Philip V on 11 April 1703 to inform him of the discovery of a new source of gold at eleven sites located three leagues $(17 \mathrm{~km})$ from Panamá, to the south of the port of Capira, and also mentioned that nine other gold mines were also discovered in the town of Capira. The king wrote on 2 November 1703 to Don Fernando Dávila Bravo de Laguna, Governor and Captain General of the Province of Terra Firme and President of the Audiencia of Panamá, to notify him of these discoveries (Proctor, 2010; Karrer, 2012).

\subsection{TISINGAL (LA ESTRELLA) LOST GOLD MINE}

There is a legend of a lost $16^{\text {th }}$ to $17^{\text {th }}$ century gold mine called Tisingal or La Estrella located somewhere in the provinces of Chiriqui, Bocas del Toro or Limón (Costa Rica). Carles (1969) wrote that a Spanish expedition set out from Santiago de Talamanca, a long abandoned town on the Panamanian side of the Río Sixaola, in 1587 to search for the legendary Tisingal gold mine, also named La Estrella, near Volcán de Chiriqui or Concepción de la Estrella (La Concepción). Brown (1910) also gave the location as Concepción de la Estrella, which was founded in 1601 supposedly near the mine (Brown, 1910), whereas others place the mine in the Talamanca Cordillera in the Río Sixaola area in Bocas del Toro or Limón (Denyer, 2001). Another legend is that mine was hidden during an Indian revolt in 1611 when the town was razed and the Spaniards were killed (Brown, 1910). Many expeditions were organized to search for the mine in Costa Rica and Panama in the $18^{\text {th }}$ and $19^{\text {th }}$ centuries (Brown, 1910; Denyer, 2001). The different accounts have conflicting dates, and Denyer (2001) concluded that the legends are an exaggeration together with confusion over similarly named places and a lack of reliable maps.

\section{The Republican period mining}

\subsection{OVERVIEW}

Panama became independent from Spain in 1821 and formed part of the Republic of Colombia until 1903, when the Republic of Panama was formed. Mining in this period was characterized by small scale vein and placer gold mining until about 1942 when gold mining stopped as a result of World War Two. A new development in the $19^{\text {th }}$ century was the influx of English and French capital in English-registered free-standing, jointstock companies (Fischer, 1975). A lesser amount of capital came from American-registered mining companies. Mining grew in the second half of the $19^{\text {th }}$ century with the arrival of a large number of foreigners, including many miners and engineers, who crossed the isthmus on their way to the California gold rush (1848-1855), and came for the construction of the Panama Railroad (1850-1855) and the French canal (1881-1889). Many of the foreigners stayed and carried out mining in Panama. Manganese mining began in the Nombre de 


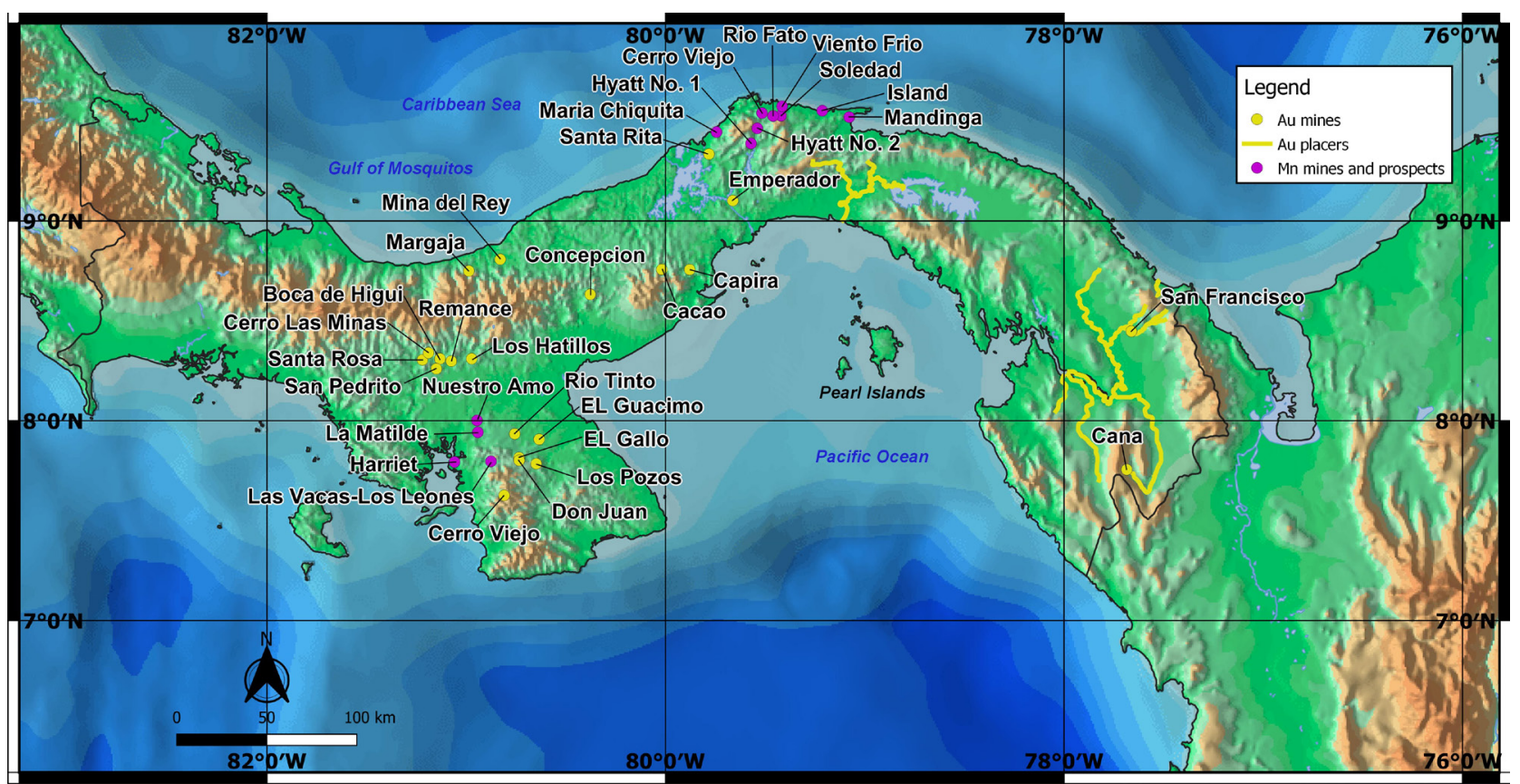

Figure 13 Map of Republican era gold and manganese mining in Panama, 1821-1942 (Map by S. Redwood).

Dios district in 1871 (Simon, 1914; Oller, 1933), the Cana gold mine was reopened in 1887-1926, several gold mines were opened in the Central Veraguas belt in the late $19^{\text {th }}$ to early $20^{\text {th }}$ centuries, and several small mines were exploited in northern Azuero (Figure 13).

The Panama City Directory of 1898 gives a snapshot of the mining industry near the end of the Colombian period (Posada, 1898). It lists 444 mine titles granted between 1887 and 1898. Of these, 369 were for gold, both alluvial and lode, four were for silver, three were for copper, one was for mercury, one was for gold-silver-lead, and 66 were for manganese. Fifty-eight titles were registered in the name of companies, and the rest were in the name of one or more individuals. Mining companies working in Panama in the late $19^{\text {th }}$ century included the Compañia Minera del Darién of Bogota at Cana; the Darien Gold Mining Company of London at Cana (1887-1914); the Santiago Gold Mining Company; the Colombian Quartz Mining Company; the Caribbean Manganese Company; The Veraguas Mining Company Limited; La Plata Mining Company Ltd. of London in Panama District (1880s); and H. Rothwell M.E. \& Company of New York, owner of claims to the Santa María, Santa Catarina and El Capitán gold vein mines near Portobello (1902) (Posada, 1898; Fischer, 1975).

The copper mines were located in the northern Azuero peninsula (Herrera Province) at Río Tinto, Ocú; Don Juan, Las Minas; and El Guácimo, Pesé (Posada, 1898). The gold-silver-lead mine was in the same district at El Gallo, Las Minas. The mercury vein mine was at Porvenir, Gorgona. Apart from mining of a small amount of high grade copper ore at El Guácimo, in the 1950s, nothing else in known about these other small mines.

Following the Thousand Day Civil War of 1898-1902, which ravaged Panama and Colombia, the Republic of Panama was created in 1903 on independence from Colombia, and the Panama Canal was built by the U.S. government from 1904 to 1914. The old Antioquian mining code of 1864, which was made law for the whole of Colombia from 1887 (Fischer, 1975), was replaced by a new Panamanian mining code in 1917 and led to a boom in claim staking. English companies continued gold mining at Cana until 1912, followed by a Panamanian company until 1926, and in Veraguas until about 1936. The most important company in this period was the Panama Corpora- 
tion Ltd. of London, managed by chairman Duncan Elliott Alves, and counted among its directors were the Earl of Cavan and Lord Melchett. The company was active from 1925-1932 with large exploration concessions in Darien, Rodriguez (west of the Canal Zone), Veraguas, Ocú, Chiriqui and Bastimiento (Bocas del Toro) (Sheridan, 1926; Riddell, 1927; Low, 1931; Norton, 1932; Oller, 1933). It was restructured as the Panama Corporation (Canada) Ltd. of Montreal in 1932 (Hull, 1940), and continued gold mining until the industry was stopped in the allied countries in 1942 as non-essential during World War 2. The company was wound up sometime between 1945 and 1951.

\subsection{ESPÍRITU SANTO DE GANA GOLD MINE}

The rediscovery of the Espíritu Santo de Cana gold mine in the 1890s, after being abandoned for almost two centuries, is a remarkable story
(Table 2; Figure 14). The Spanish accounts of the fabled, rich gold mine aroused the interest of Vicente Restrepo, a Colombian metallurgist and later a government minister, who is best known for his book A Study of The Gold and Silver Mines of Colombia, first published in 1884 (Restrepo, 1886, 1888, 1952). In 1883 he formed the Compañía Minera del Darien in Bogota to stake the mine. He sold it in 1887 it to the Darien Gold Mining Company Ltd., an Anglo-French company based in Manchester, England, which was managed by the industrialist Richard Hammersley Heenan of Heenan and Froude Ltd., and whose English directors included Lord Charles Beresford, Colonel Edis of the Artists' Rifle Volunteers, and Arthur Coventry of Smith and Coventry Ltd. (Restrepo, 1888; Woakes, 1923). It initially mined the El Rey Mine (or North Mine) but with poor results. In 1892-1894 it rediscovered and reopened the Espíritu Santo Mine, where it found five wooden
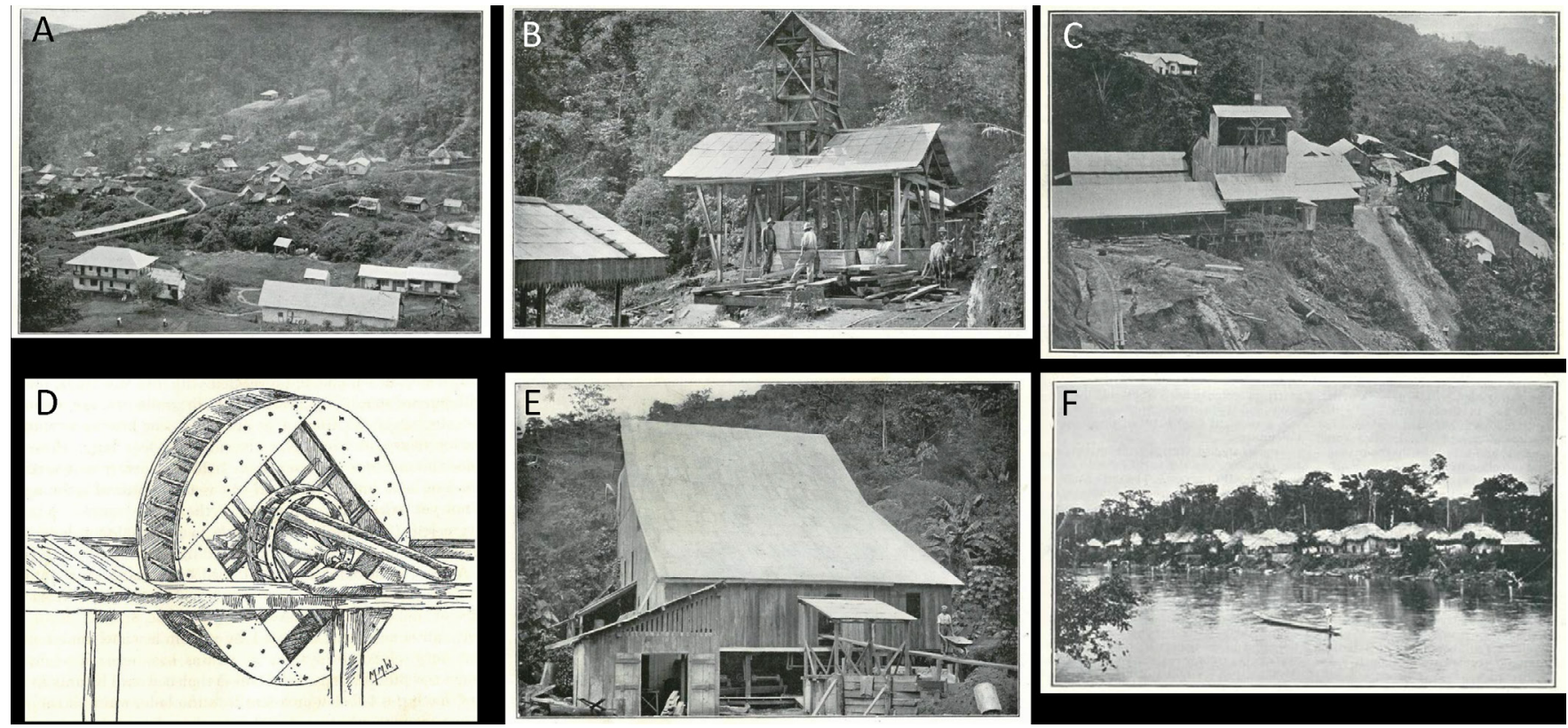

Figure 14 Photographs of the Cana gold mine between 1892 and 1907 taken by Ernest Woakes when he was the mine manager (photographs from Woakes, 1899, 1923). A) Overview of the large mining camp or town at Cana. The roofed bridge carried a tramway from the mine to the plant. B) The Heenan Engine Shaft at the Espíritu Santo mine. C) The Maisounabe Shaft and 40-stamp mill at the Espíritu Santo mine. D) Five old Spanish wooden tread-wheels about $3.65 \mathrm{~m}$ in diameter for pumping water were found when the Espíritu Santo mine was rediscovered and dewatered in 1894 . They date from the early $18^{\text {th }}$ century. E) The stamp mill at the Espíritu Santo mine. F) The Indian village at Boca de Cupé on the Tuira River. This was near the head of river navigation for canoes carrying cargo and machinery. A $50 \mathrm{~km}$ long mule trail led from here to the mine, and was replaced by a narrow gauge railway in 1907. Passengers were taken to El Real, lower down on the Tuira River. Transport from Panama to El Real was by small schooners which took 7 days, until replaced by a steam launch in 1897 which reduced the journey to 24 hours. 

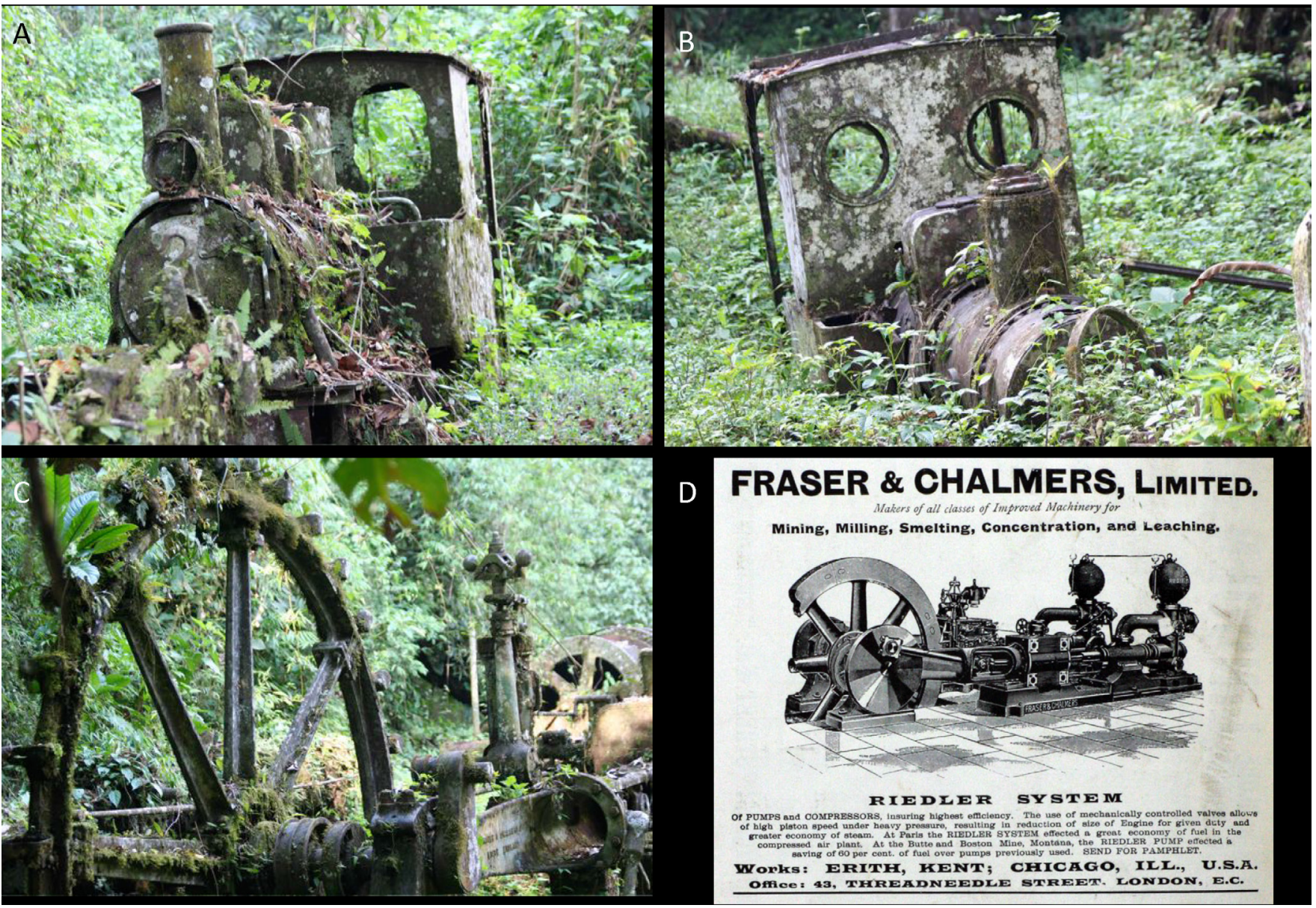

\section{FRASER \& CHALMERS, LIMITED.}

Mining, Milling, Smelting, Concentration, and Leaching,

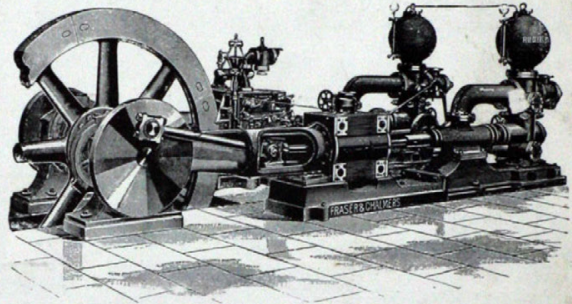

RIEDEER SYSTEM

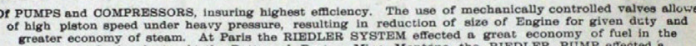

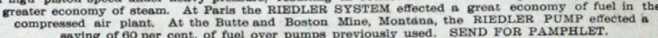

Works: ERITH, KENT; CHICAGO, ILL., U.S.A. OFICO: 43, THREADNEEDLE STREET. LONDON, E.C.

Figure 15 The industrial heritage of the Cana mine. A, B) Two abandoned light steam locomotives from the $50 \mathrm{~km}$ long, $60 \mathrm{~cm}$ narrow gauge railway from Boca de Cupé to the mine built in 1907. They were manufactured by Orenstein \& Koppel of Germany at Drewitz in Potsdam, near Berlin, a specialist in light railway locomotives. The larger engine (A) is 30 to $40 \mathrm{hp}$, and the smaller one (B) is $20 \mathrm{hp}$. C) A steam-powered pumping engine manufactured by Fraser $\&$ Chalmers, Limited at Erith, Kent, England. There are also winch drums from the shaft and railway carriages at the site. D) Advertisement by Fraser $\&$ Chalmers for a similar steam engine. Photographs taken in 2009 by Dr. Glyn Dawson, Chicago and published with his permission. Thanks to Jeremy Martin, London for identifying the locomotives. A similar steam pump also exists at the El Formón mine on the Rio Belen, Veraguas gold district, as illustrated by Méndez (2013) (John Griggs, pers. comm., 19 April 2009).

treadmills, used by the Spaniards to dewater the mine, preserved under water for almost two centuries (Figure 14D; Woakes, 1895, 1899, 1923). This mine became profitable for several years and the company paid an average annual dividend of 23.3\% between 1892 and 1903 (Rippy, 1953; Fischer, 1975).

However, the company went bankrupt in 1907. A new company was set up in England in 1907 with the same name, The Darien Gold Mining Co. Ltd., but was controlled by the French interests. A $50 \mathrm{~km}$ long narrow gauge railway was built from Boca de Cupé at the limit of navigation on the Tuira River to the mine in 1907; the steam locomotives and wagons can still be seen at the site (Figure 15). The restructured company mined from 1908-1912. Once again the mine became bankrupt and it was acquired in 1914 by one of the creditors, Don Tomás Arias, who had been one of the members of the Provisional Government Junta (1903-1904) of the new Republic of Panama, but it is not known how much gold was produced in this period, and the mine closed in 1926. The production from 1895-1910 was given as 230,443 ounces $(7,168 \mathrm{~kg})$ by Tower (1963) at grades of 45-70 g/t, and for 1900-1907 it was recorded as 142,236 ounces $(4,424 \mathrm{~kg})$ by Oller (1933). Subsequently, the Panama Corporation Ltd. explored 
Cerro San José as a bulk mineable gold target in 1927-1932 and estimated reserves of $1.8 \mathrm{Mt}$ at 1 $\mathrm{g} / \mathrm{t} \mathrm{Au}$, with potential for $11 \mathrm{Mt}$ (Foster, 1939). This was the first instance of the evaluation of a bulk mineable hard-rock gold deposit in Panama, as opposed to an alluvial or gold vein-type deposit, a type of deposit that would not be economic to mine for another half century until the strong rise in the gold price in the 1980s.

\subsection{DARIEN PLACER GOLDFIELD}

The Ríos Tuquesa, Chuqunaque, Balsa and Sabalo (or Tucuti) placer gold deposits of the Darien placer goldfield were evaluated by the Panama Corporation Ltd in 1928-1931 (Sheridan, 1926; Low, 1931, Hull,1940) and by the Isthmian Corporation in 1941 (Stranahan, 1941). Gold exports from Darien in 1931-1941 averaged 5,200 ounces $(161.7 \mathrm{~kg})$ a year with a peak of 13,895 ounces (432.2 kg) in 1934 (Roberts and Irving, 1957). Pitting and churn drilling by the Panama Corporation Ltd on the Río Balsas and its tributary the Río Sabalo, near Tucutí, in 1928-1931, defined reserves of 4.1 million cubic yards (3.1 $\mathrm{Mm}^{3}$ ) with a value of 18.36 cents per cubic yard $\left(163 \mathrm{mg} / \mathrm{yd}^{3}\right.$ or $216 \mathrm{mg} / \mathrm{m}^{3}$ at the then gold price of $\$ 35$ per ounce) containing about 21,500 ounces (669 kg) of gold (Low, 1931; Hull, 1940).

The Río Tuquesa placer deposits are probably the largest in Panama and the broad reaches of the lower part of the river were described as suitable for mining by dragline and bucket-wheel dredges. The placer deposits were evaluated by the Panama Corporation Ltd in 1928-1931 by pitting and churn drilling and were estimated to contain resources of 184 million cubic yards $\left(140 \mathrm{Mm}^{3}\right)$ with a value of $\$ 0.72-\$ 0.98$ per cubic yard $(640$ $871 \mathrm{mg} / \mathrm{yd}^{3}$ or $747-1143 \mathrm{mg} / \mathrm{m}^{3}$ ) containing $104-$ 160 t (3.36-5.15 Moz) of gold (Sheridan, 1926). In 1941 the Isthmian Corporation estimated resources of 155 million cubic yards $\left(119 \mathrm{Mm}^{3}\right)$ with a value of $\$ 1.043$ per cubic yard (927 mg/ $\mathrm{yd}^{3}$ or $1206 \mathrm{mg} / \mathrm{m}^{3}$ ) containing $143 \mathrm{t}(4.6 \mathrm{Moz})$ of gold (Stranahan, 1941). Attempts were made to mine the Tuquesa in the 1930 s by a German company with a small drag-line, and in the 1950s by a suction dredge. The most recent evaluation was carried out by Tuquesa Mining S.A. in 19711979. The River Pito placer gold deposits, on the Caribbean drainage, were evaluated by UNDP in 1971 (UN, 1972b).

\subsection{GHEPO PLACER GOLDFIELD}

In the Chepo district, east of Panama City, there is placer gold on the Ríos Terable, Bayano and Mamoni. Alluvial gold mining on the Río Bayano near El Llano was described by Oller (1933). In 1941, the Isthmian Corporation estimated reserves of 150 million cubic yards $\left(115 \mathrm{Mm}^{3}\right)$ at $35 \mathrm{c}$ per cubic yard $\left(311 \mathrm{mg} / \mathrm{yd}^{3}\right.$ or $400 \mathrm{mg} /$ $\left.\mathrm{m}^{3}\right)$, containing $46 \mathrm{t}(1.5 \mathrm{Moz})$, between the Río Terable and the town of Pintuko (Stranahan, 1941). SGI (1991a) studied a placer gold deposit in terraces over $20 \mathrm{~km}$ in length on the upper Río Mamoni that was being mined at the time by a large number of artisanal miners.

\subsection{VERAGUAS GOLDFIELD}

In 1882 it was reported that the old veins at Margaja, owned by Señor Fabrega, the new claims of the Veraguas Company, and the properties owned by Señor Cisneros and others would have work done on them during the coming season (The New York Times, 5 August 1882).

The best known vein deposit in the Veraguas goldfield is the Margaja Mine in the upper part of the Cocuyo gold placer district of the Río Santiago. It was mined by Veraguas Mines Ltd. on lease from the Panama Corporation (Canada) Ltd in 1933-1936 and produced 30,094 ounces (936 $\mathrm{kg}$ ) of gold, 20,269 ounces (630 kg) of silver and 427,169 lb (194 metric tons) of copper from 28,923 tons (26,239 metric tons) of ore. The mine had five levels up to $177 \mathrm{~m}$ long. Ore shoots graded more than $1,000 \mathrm{~g} / \mathrm{t} \mathrm{Au}$ with a maximum sample of 2,722 $\mathrm{g} / \mathrm{t}$ over $2.5 \mathrm{~m}$ vein width (1934 mine plan). It was evaluated by UNDP in 1967 and 18 check samples gave an average grade of $130.0 \mathrm{~g} / \mathrm{t}$ over $0.80 \mathrm{~m}$ vein width (Hull, 1940; Wleklinski, 1969). 
The Cocuyo-Guinea deep-lead placer gold deposit was evaluated by the Panama Corporation Ltd in 1928-1931 (Low, 1931), and by the UN program in 1965-1969 (Wleklinski, 1969). Quartz-gold veins were described at Mina del Rey (or Palenque) on the River Belén by Taylor (1852).

\subsection{GENTRAL VERAGUAS GOLD BELT}

Several British companies explored and mined in the Central Veraguas gold belt is the late $19^{\text {th }}$ and early $20^{\text {th }}$ centuries, namely the Santiago Mining Company (1888-1889), the Colombian Quartz Mining Company (1891-1897), the Veraguas Mining Company Ltd. of Glasgow (founded 1897), and the Panama Corporation Ltd (1927-1932) (Low, 1931; Oller, 1933).

The Los Hatillos gold mine was developed by the Panama Corporation Ltd. in 1926-1932. It discovered the La Blanca-La Cuelga vein and defined a reserve of 11,000 tons grading $14.0 \mathrm{~g} / \mathrm{t}$ $\mathrm{Au}, 3.1 \% \mathrm{~Pb}$ and $4.3 \% \mathrm{Zn}$.

The Remance gold deposit was mined intermittently since the mid- $18^{\text {th }}$ century with total known gold production of about 120,000 ounces $(3,732 \mathrm{~kg})$. In about 1900, the Veraguas Mining Company mined 15,500 tons at $10.5 \mathrm{~g} / \mathrm{t}$ Au for 5,183 ounces $(161 \mathrm{~kg})$. It was explored in 19251931 and mined in 1931-1932 by the Panama Corporation Ltd. which produced either 14,000 or 70,000 tons at $10.7 \mathrm{~g} / \mathrm{t}$ Au to produce between 5,332 and 27,124 ounces (166 to $844 \mathrm{~kg}$ ) (Riddell, 1927; Low, 1931; Wleklinski, 1969). The first gold shipment of 20,287 ounces (631 kg) from Los Hatillos and Remance was made in August 1931 (Star and Herald, Panama, 21 August 1931).

The San Pedrito gold mine was explored by the Panama Corporation Ltd. in 1927-1932 with adits and trenches, and an attempt was made to mine it in 1938.

The Santa Rosa and Alto de la Mina gold deposits near Cañazas were first recorded to have been mined in the late 1800s. In 1882 it was reported that Messrs. Schuber and Farraud were working the old Cañasa mines using arrastra mills and recovered "several very respectable bars" (The
New York Times, 5 August 1882; Anon, 1882). Alto de la Mina was mined on a small scale by the Panama Corporation in 1927-1932, and Santa Rosa was mined in 1935-1940 (Wleklinski, 1969). The Cerro Las Minas Au deposit, 3 km north of Cañazas, has mine workings which date from the early 1900s.

\subsection{SANTA RITA GOLD MINE}

The old Santa Rita gold mines near Sabaneta, Colón, are shown on maps of 1829 (Lloyd, 1829) and 1857 (Harrison, 1857). The mines were reopened in 1882 by Messrs. Thorington and Griffin, and were owned by Porfirio Meléndez from 1889 until the end of the century (Posada, 1898); the subsequent history is not known. Woodring described the geology and the mine remains in 1957 (Woodring, 1957). The Dirección General de Recursos Minerales (DGRM) carried out exploration at Santa Rita including a helicopter-borne magnetic survey, trenching and drilling as part of the government-funded Gold Project in 1979-1982.

\subsection{EMPERADOR GOLD DEPOSIT}

Gold was mined from placers and epithermal quartz veins in the Emperador deposit in the upper parts of the Río Sardinilla and Quebrada de Oro (Gold Creek), tributaries of the Río Obispo (now part of the Panama Canal) and the Río Chagres respectively, in the former Emperador (Empire) district (Table 3; Redwood, 2020b). Mining was carried out in Spanish times and again from about 1860-1900 by several companies including the Pasiga River Mining Company (1876), the Emperador Mining Company (1882-1886), the Societé Mercier and Co. (1886-1889), the Colombian Gold Mining Company of Ohio (1889- 1900), and the Quebrada de Oro Plantation and Mining Company ( 1900-1919) (Redwood, 2020b). The latter tried unsuccessfully to claim compensation from the U.S. Government in 1914-1919 for expropriation of the land in the Canal Zone. The total gold production is unknown but was small. 
Table 3. The history of the Emperador gold mine.

\begin{tabular}{|c|c|}
\hline Year & Owners and Events \\
\hline $\begin{array}{l}\text { 16th to early } \\
18 \text { th Century }\end{array}$ & Mined by the Spaniards. \\
\hline 17 th century & Gold was mined near Venta de Cruces, probably a reference to Emperador. \\
\hline $1860 \mathrm{~s}$ & $\begin{array}{l}\text { Rediscovered by William Thompson, a Panama Railroad conductor. He formed a company to work the } \\
\text { mine. Dug a ditch from the upper Chagres river to Quebrada de Oro for hydraulic mining. }\end{array}$ \\
\hline 1870 & Sardinilla Chiquita granted to William Nelson and 3 other Americans. \\
\hline 1873 & William Thompson and a Philadelphia company set up a 5 stamp mill at Sardinilla. \\
\hline 1875 & $\begin{array}{l}\text { Messrs. Furth and Campbell granted Sardinilla Chiquita. Sold it in } 1878 \text { to Mr. Wurlitzer who installed } \\
\text { machinery. }\end{array}$ \\
\hline 1876 & The Pasiga River Mining Company obtained the mine from Messrs. Furth and Thompson. \\
\hline 1882 & $\begin{array}{l}\text { Emperador Mining Company of Colombia set up with capital from Denver by Henry C. Singer. Singer } \\
\text { was murdered in a bar at Emperador in } 1882 \text {. }\end{array}$ \\
\hline 1883 & $\begin{array}{l}\text { Charles H. Burns and } 46 \text { others arrested in Emperador on suspicion of theft of } \$ 50,000 \text { of U.S. Navy gold } \\
\text { coin from the Panama Railroad. They were released without charge after } 3 \text { months. The gold was never } \\
\text { found. }\end{array}$ \\
\hline 1883 & $\begin{array}{l}\text { Bernardo Mercier became owner of the Emperador Company property. It applied for the Sardinilla- } \\
\text { Quebrada de Oro claim in } 1883 \text { and was granted title in 1884, and staked other claims. Mercier and others } \\
\text { were former employees of the French Canal Company. }\end{array}$ \\
\hline $1886-1893$ & $\begin{array}{l}\text { Basil Burns Duncan (aka Charles H. Burns) obtained a half interest in the Sardinilla-Quebrada de Oro and } \\
\text { Veta 1886-1893 Madre claims from the Emperador Mining Co. in } 1886 \text { and formed a partnership with } \\
\text { Mercier, the Societe Mercier \& Co. He obtained the mining rights to } 11 \text { concessions between } 1889 \text { and } \\
1893 .\end{array}$ \\
\hline $1891-1892$ & $\begin{array}{l}\text { Duncan transferred the claims to the newly formed The Colombian Gold Mining Company of Ohio. } \\
\text { Installed a 1891-1892 Huntington Centrifugal Rock Crusher powered by a steam engine and started } \\
\text { operations in 1891. In } 1892 \text { it installed a Dodge Rock Breaker. There is more no news after } 1892 \text {. The } \\
\text { mine later ceased operation. }\end{array}$ \\
\hline 1890s? & $\begin{array}{l}\text { The Colombian Gold Mining Company later changed its name to Quebrada de Oro Plantation and Mining } \\
\text { Company and invested in agriculture. }\end{array}$ \\
\hline 1914-1919 & $\begin{array}{l}\text { The Quebrada de Oro Company, represented by Mr. Duncan, presented a claim for compensation for loss } \\
\text { of land to the Canal Zone to the U.S. Government. }\end{array}$ \\
\hline 1957 & The remains of the mine were described as old adits, machinery and rails. \\
\hline
\end{tabular}

\subsection{GAPIRA GOLD DISTRICT}

Gold mining was carried out from epithermal veins in the Capira district from 1703 until the late $20^{\text {th }}$ century (Table 4 ). Small scale vein mining was carried out by multiple owners in the $18^{\text {th }}$ to early $20^{\text {th }}$ centuries (Mérida, ca1995). The district was owned from 1927-1951 by the Panama Corporation Ltd. and Las Minas de Campana S.A., a subsidiary of Panaminas Inc. that was, in turn, owned by the U.S. Vanadium Company and Union Carbide Group, which bought all the small lode claims to consolidate ownership of the district. They mined at La Trinidad gold mine on the Buho vein at Cerro Buho, in the southern part of the district by means of a shaft and two under- ground levels in 1930-1942 (SGI, 1991a). The ore reserves in 1941 were given as 53,300 t grading $12.8 \mathrm{~g} / \mathrm{t}$ gold.

The Capira district was later explored by Pavonia S.A. (Canadian Javelin Ltd.) and Panaminas S.A. from 1968-1973, Texasgulf in 1978, and Petro-Panama S.A. in 1980. Compañía Minera La Trinidad explored the La Trinidad mine from 1988 and defined proven reserves of $115,000 \mathrm{t}$ at $7 \mathrm{~g} / \mathrm{t} \mathrm{Au}$, and probable reserves of 200,000 t at $5 \mathrm{~g} / \mathrm{t}$ Au (SGI, 1991a). Swedish Geological International carried out exploration at Capira in 1988-1990 (SGI, 1991a). It identified 13 veins with grades up to $18 \mathrm{~g} / \mathrm{t}$ Au over $1.2 \mathrm{~m}$ in a zone $1,500 \mathrm{~m}$ long with zones of alteration up to $30 \mathrm{~m}$ wide. SGI evaluated five veins in detail (Brenda, 
Table 4. The history of the Capira gold district.

\begin{tabular}{|c|c|}
\hline Year & Owners and Events \\
\hline 1522 & Pre-Columbian mining in Capira referred to in founding of Nata. \\
\hline 1703 & New veins discovered in Capira district. \\
\hline 18th-19th Centuries & Small scale vein mining. \\
\hline $1848-1858$ & $\begin{array}{l}\text { Trinidad de las Minas in Cacao mined by Manuel María de la Victoria y Urbina. Produced } 5712 \text { oz Au } \\
\text { in } 1850 \text { and } 1858 .\end{array}$ \\
\hline 1850 & $\begin{array}{l}\text { Mina La Bogotana staked north of La Trinidad mine by Daniel Valdeé y Valdés, Cirilo Escobar and } \\
\text { Salomon Cifuente. }\end{array}$ \\
\hline 1880 & $\begin{array}{l}\text { El Real de Mina de Capira staked by José Ramón Riveros and Agustín Riveros. The mine previously } \\
\text { produced } 3775 \mathrm{oz} \mathrm{Au.}\end{array}$ \\
\hline $1882-1897$ & $\begin{array}{l}\text { Ten mines staked called La Batea, Mina Del Oro, Maria, La Colombiana, Mina Rica, La Dificil, Liberal, } \\
\text { Dichosa, Sonora, La Aguafuerte. }\end{array}$ \\
\hline 1910 & Mina La Esperanza formed in Bogota, represented by Dr. Eusebio Morales. \\
\hline $1917-1930$ & 108 claims staked. \\
\hline $1927-1951$ & $\begin{array}{l}\text { Panama Corporation Ltd, England and Las Minas de Campana S.A. (subsidiary(?) of Panaminas Inc. in } \\
\text { turn owned by U.S. Vanadium Corporation and Union Carbide Group) JV bought all the claims 1927- } \\
1939 .\end{array}$ \\
\hline 1930-1942 & Mined the Buho vein at the Trinidad mine. \\
\hline $1930 \mathrm{~s}-1940 \mathrm{~s}$ & Panama Corporation mined La Florida at Cacao. \\
\hline 1951-1968 & No activity. \\
\hline $1968-1973$ & Pavonia S.A. (Canadian Javelin Ltd) exploration. \\
\hline 1978 & Texasgulf exploration. \\
\hline 1980 & Petro-Panama S.A. (PETROPASA) exploration. \\
\hline 1988-1990s & Compania Minera La Trinidad explored La Trinidad mine. \\
\hline $1988-1990$ & Swedish Geological A. B. regional exploration and drilling. \\
\hline $1991-2020$ & Capira Dorada S.A., Panama exploration of Capira and Cacao. \\
\hline
\end{tabular}

Flor, Dani, Madrid and Suecia), with trenching and 7 diamond drill holes $(641.5 \mathrm{~m})$ on the Brenda and Flor veins, and a best intersection of $1.2 \mathrm{~m}$ at $2.3 \mathrm{~g} / \mathrm{t} \mathrm{Au}$.

The veins at Cacao were mined at La Florida by the Panama Corporation (Canada) Ltd. in the 1930s and 1940s. The deposit was evaluated by the regional geochemical survey by SGI in 19881990 which identified a large zone of alteration with quartz veinlets with low gold grades (SGI, 1991a). Follow up exploration by SGI included 89 chip samples with values of 0.02 to $2.21 \mathrm{~g} / \mathrm{t}$ Au. Since 1991, Capira and Cacao have been explored by Capira Dorada S.A. of Panama.

\subsection{MANGANESE MINING IN THE NOMBRE DE DIOS BELT}

Manganese mining and exploration were carried out intermittently in the Nombre de Dios belt from 1871 until after the First World War, as a result of high prices, and then intermittently until the 2000s (Table 5). The Nombre de Dios belt extends from Maria Chiquita to San Blas, and south to the Río Boqueron in a zone of $75 \mathrm{~km}$ length E-W by 20 km wide (Simon, 1914; Sears, 1919; Simons, 1957). The deposits outcrop or form large residual blocks and boulder trains due to the hardness of the ore. The main manganese district is south of Nombre de Dios to Viento Frio where the principal deposits are Cerro Viejo in the west (the America, Maria-Defense, June and Mariana mines and prospects), Río Fató in the middle (the Monstroncosa, Mangue de Indio, Panama or Ventura, Machita, Blaque and La Mesa mines and prospects) and Soledad in the east (the Soledad, Concepción and Carano mines). The zone continues to the SE along the Río Boqueron to the Hyatt No. 1 and 2 mines.

Small scale manganese mining was first carried out at Viento Frio in 1871-1875. Mining started again in 1889, and 66 mining claims were staked by 1898 (Oller, 1933). The Caribbean Manganese Co. of West Virginia was formed in 1892 and built 
Table 5. The history of the Nombre de Dios - Viento Frio manganese mines.

\begin{tabular}{|c|c|}
\hline Year & Owners and Events \\
\hline $1871-1875$ & Manganese mining at Viento Frio. \\
\hline $1889-1898$ & 66 mining claims staked for manganese. \\
\hline $1895-1902$ & $\begin{array}{l}\text { The Caribbean Manganese Co., West Viriginia mined } 36,300 \text { t of } 53.7 \% \mathrm{Mn} \text { at the Soledad mine. Narrow } \\
\text { gauge railway to Playa de Damas. The nearby Concepción mine produced } 10,900 \mathrm{t} \text {. }\end{array}$ \\
\hline 1902 & Replaced by the Panama Colombia Company. \\
\hline 1915 & The Hyatt deposits were discovered by a rubber cutter. \\
\hline 1920 & $\begin{array}{l}\text { The Hyatt Panama Manganese Co. built a narrow-gauge railway from the Hyatt No. } 2 \text { mine to Nombre } \\
\text { de Dios, but it did not produce much. }\end{array}$ \\
\hline 1993 & $\begin{array}{l}\text { The Caribbean Mining Company mined Cerro Viejo and Soledad for several years at planned 5,000 } t \text { at } \\
45-55 \% \text { Mn per month. }\end{array}$ \\
\hline $2008-2010$ & Exploration by Global Min-Metal S.A. \\
\hline
\end{tabular}

a narrow-gauge railway from Playa de Damas, north of Nombre de Dios, to the Soledad mine, south of Viento Frio, in 1895. It shipped about 40,000 tons (36,300 metric tons) of high grade manganese ore grading $53.7 \%$ Mn between 18951902, however the operation was abandoned as a result of the Thousand Day War and the company was replaced by the Panama Colombia Company (Simon, 1914). The Concepción mine, about $3 \mathrm{~km}$ north of Soledad, produced 12,000 tons $(10,900$ metric tons) of ore in the same period (Simon, 1914). The Hyatt deposits were discovered by a rubber cutter in 1915, and the Hyatt Panama Manganese Co. built a narrow-gauge railway from Nombre de Dios to the Hyatt No. 2 mine on the River Boqueron in 1920, but it was abandoned a few years later. The Hyatt mines produced very little ore, although Sears (1919) estimated potential for 15,000 tons (13,600 metric tons) of high grade ore at each deposit. The manganese mines were worked intermittently throughout the $20^{\text {th }}$ century although the history is not known in detail. The Caribbean Mining Company mined the Cerro Viejo and Soledad deposits from 1993 for several years with planned production of 5,000 metric tons of $45-55 \%$ Mn per month. Most recently, Global Min-Metal S.A. carried out exploration in 2008-2010.

The only other manganese deposits to have been mined in Panama are at Mandinga Bay at the western end of the Gulf of San Blas, about 40 $\mathrm{km}$ west of the Soledad deposit. They were mined in 1916-1919 and produced 21,310 long tons
(19,260 tonnes) with 25-30\% Mn and 40-50\% silica (Simons, 1957). The Island deposit occurs on a small island near the coast between the Mandinga Bay and Viento Frio deposits. It produced 23,000 tons (20,999 tonnes) of manganese ore in the 1895-1902 period (Simon, 1914).

A second belt of manganese prospects occurs between Atalaya and the Gulf of Montijo in Veraguas. The belt was discovered by the Panama Corporation Ltd. in 1927 which estimated potential for several million tonnes of manganese ore at Matilde and several hundred thousand tonnes at Bahia Honda (Riddell, 1927). Three of the prospects were described by Simons (1957) based on a 1942 visit. Two other prospects were explored by the DGRM and the UNDP program in 19641972, with 5 shallow drill holes (UN, 1972a). None of these deposits have been mined.

\section{The regional exploration and porphyry copper discovery era}

\subsection{OVERVIEW}

The period of regional exploration and porphyry copper discoveries from 1956 to 1982 began with the start of bauxite and copper exploration in 1956, and continued with major regional exploration programs. These were the result of a government policy of mineral exploration and evaluation of known deposits which began in 1957 (Quirós, 1975) under President Ernesto de la Guardia 
(1956-1960). The first mining authority, the Mineral Resources Administration (ARM), was created in 1963 under the auspices of the Ministry of Agriculture, Commerce and Industry. A new mining law was approved in 1963 and became law in 1964 during the administration of President Roberto Chiari (1960-1964). These policies set out the path for the Panamanian mining industry to this day. The 1964 mining law is still valid but is now antiquated and in need of change. The ARM became the General Directorate of Mineral Resources (DGRM) under the new Ministry of Commerce and Industry in 1970.

The first regional exploration programs were made by American mining companies for bauxite in western Panama from 1956 until the 1960s. The first regional government exploration program was carried out in 1963 to 1965 as part of the Rural Cadastral Project of Land and Water funded by the Alliance for Progress of the USA. Regional stream sediment exploration programs and follow up were carried out in 1965 to 1974 by the United Nations Development Programme (UNDP) of New York, an international agency newly formed in 1965, together with the government counterpart ARM/DGRM. The project eventually ran to three phases: 1) the Phase I Azuero Mining Project in the Azuero Peninsula and Veraguas from 1966 to 1969; 2) the Mining Project Phase II in Bocas del Toro, eastern San Blas, the Majé Massif and the Pirre Massif from 1969 to 1972; and 3) the Mining Project Phase III in Las Palmas, Soná and the Island of Coiba from 1973 to 1974 (UN, 1968, 1969a, 1969b, 1972a, 1972b, 1972c, 1981; del Giudice and Recchi, 1969; Wleklinski, 1969). As part of the project, a regional aeromagnetic survey was carried out by Huntec Limited of Toronto. These regional programs were very successful and resulted in the discovery of the Petaquilla (Cobre Panama) porphyry copper deposit in 1968; copper at the Cerro Quema epithermal gold-copper deposit in 1967, although the gold potential was not recognized for another two decades; the Palmilla porphyry copper prospect in 1969; the Río Pito and San Blas porphyry copper prospects in 1970; and the Ipeti porphyry copper prospect in 1971 (Figure 16). A stream sediment survey carried out at the same time in Chiriqui province by a major mining company, Asarco, discovered the Cerro Chorcha porphyry copper prospect. Resource definition and feasibility studies were undertaken by foreign companies with state participation at the Cerro Colorado deposit in 19691982 and the Petaquilla deposit in 1971-1980 and it was anticipated that Panama would develop a major copper mining industry, but the low copper price meant that the deposits were not economic at the time and the projects were terminated.

The only mining project to enter production in this period was the exploitation of marine black sands for iron ore and titanium in the Gulf of Panama by Hierro Panama S.A., a Japanese-Panamanian joint venture (1971-1972), which ended prematurely when the loading dock was wrecked (Quirós, 1962, 1975; SGI, 1991a).

Following the termination of the UNDP mineral exploration program, the DGRM itself carried out government-funded exploration programs for gold from 1975 to 1982, namely the Experimental Project (1975-1977) at Río Mogue in Darien, followed by the Gold Project (1979-1982) that trenched and drilled several gold projects in the Central Veraguas gold district (Remance, Alto de las Minas, Hatillo, Santa Rosa) and Santa Rita in Colón (SGI, 1991a).

The DGRM published a new geological map of Panama at 1:500,000 scale in 1976, which was updated in 1995, and a set of geological maps at 1:250,000 scale in 1991 (DGRM, 1991). The only previous geological maps were in the first memoir on the geology of Panama by Terry (1956), and a detailed map and memoir of the geology of Canal Zone at 1:75,000 scale by Woodring (1957), which was updated at 1:100,000 scale in 1980 (Stewart et al., 1980; Woodring, 1982).

The two major copper projects, Petaquilla and Cerro Colorado, were of great political importance to Panama during the presidency of General Omar Torrijos (1968-1981) who saw them as a solution to Panama's debt, as potentially important economic developments for the poorer provinces of western Panama, and as a diversification in both geography and economy away from the canal (Gjording, 1991). One of the contentious issues was that the 


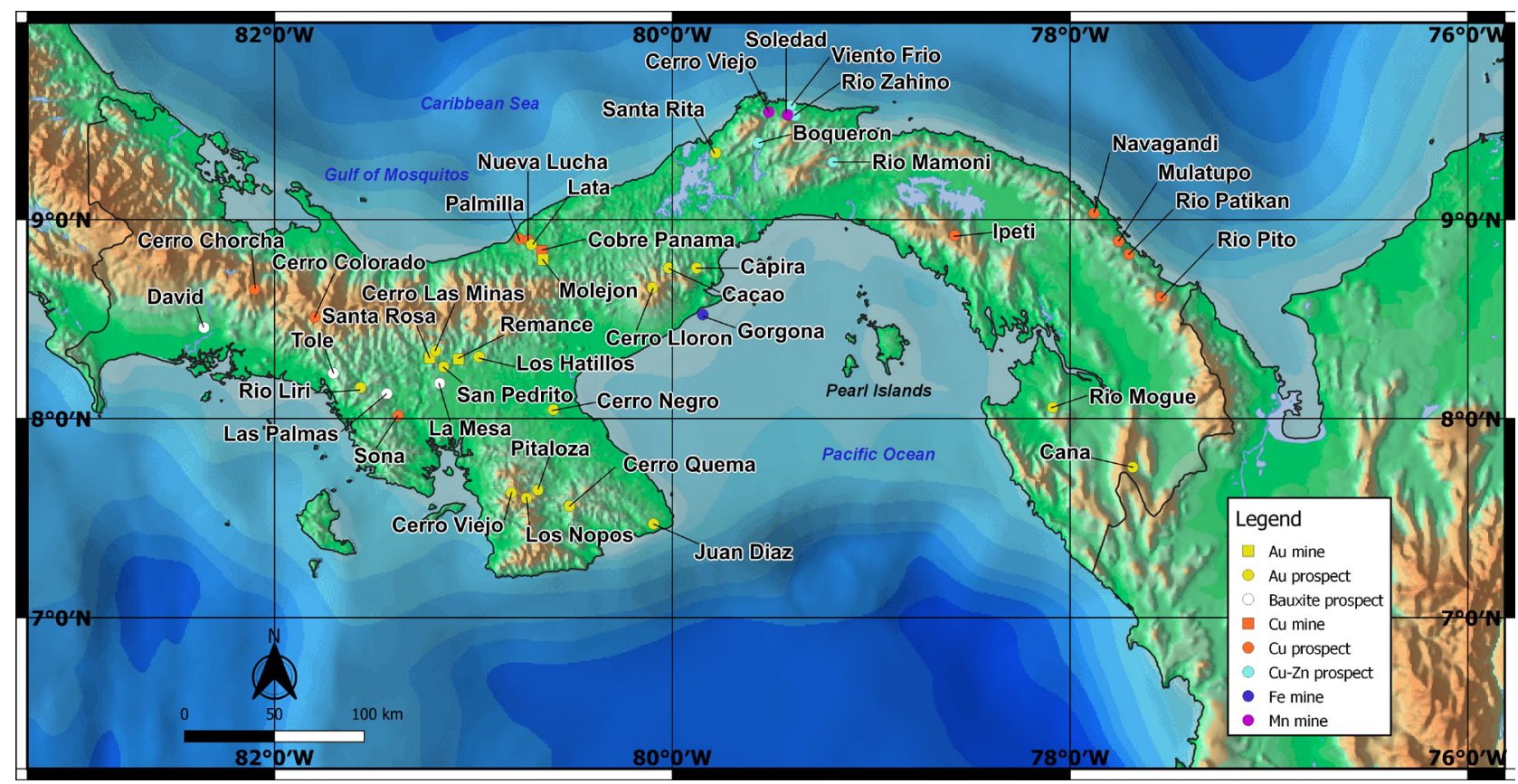

Figure 16 Map of the modern mines and mineral deposit discoveries of Panama, 1956-2020 (Map by S. Redwood).

government insisted on majority control of the project. This was the period when nationalization was in vogue, and the major copper producing countries of Chile, Zaire and Zambia expropriated mines between 1969 and 1974. During the same period Torrijos negotiated the return of the canal by the USA at the end of the century in the famous Torrijos-Carter Treaties of 1977.

\subsection{GHIRIQUI-VERAGUAS LATERITIC BAUXITE AND IRON ORE DEPOSITS}

The Chiriqui bauxite deposits, located in a 145 $\mathrm{km}$ long belt between Las Palmas in Veraguas and Tolé and David in Chiriqui in western Panama, were discovered and evaluated from 1956 to the 1960s by two major American aluminum companies, the Aluminum Company of America (Alcoa) and Kaiser Aluminum Company. They estimated resources of $70 \mathrm{Mst}(64 \mathrm{Mt})$ of bauxite grading $40 \% \mathrm{Al}_{2} \mathrm{O}_{3}$ and $6 \% \mathrm{SiO}_{2}$ (Wilmot, 1960; Patterson, 1967; Quirós, 1962, 1975; del Giudice and Recchi, 1969; Ferenčić, 1971; Patterson et al., 1986). A lateritic iron ore prospect at La Mesa, about $20 \mathrm{~km}$ west of Santiago, on the Meseta de Veraguas (or El Alto de la Mesa) plateau, first described by Riddell (1927), was also evaluated during this period (del Giudice, 1965). None of these deposits have been exploited.

\subsection{GERRO GOLORADO PORPHYRY GU DEPOSIT}

The Cerro Colorado porphyry copper deposit is located in the Central Cordillera of western Panama (Figure 2; Table 6). Copper veins were first reported in the area in 1865 by Charles T. Bidwell, FRGS, the British Vice-Consul in Panama, in his book "The Isthmus of Panama", quoting from a report by the Government of New Granada dated 1859. "There are copper-mines near San Feles [San Felix], and near the road going from Boca del Toro to David" he wrote (Bidwell, 1865, p. 336).

Robert A. Terry, a Sinclair Oil Company geologist, traversed the cordillera on foot in April 1936 and observed a quartz vein with chalcopyrite and green malachite-stained rock, but he did not publish this find until his 1956 memoir about Panama, in which he wrote "copper ... occurs as low-grade sulphide deposits ... near the head of Río San Felix" (Terry, 1956; Texasgulf, 1978; Linn et al., 1981a). This was followed up by a prospector and led to the discovery of Cerro Colorado in 1957.

Joe (José) Zarn, a Yugoslavian prospector living in Panama, contacted Terry in 1955 to ask about 
the location of the copper showings (Terry, 1955, personal letter to Mr. Joe Zarn, cited by Linn et al., 1981a). Terry indicated that the area was in the upper headwaters of the Río San Felix (Terry, 1956; Linn et al, 1981a). With the backing of Pablo Pinel, a Panamanian businessman, Joe Zarn and Luis Serrano, Terry's guide from the 1936 expedition, made several expeditions from the village of San Felix. After being turned back by the Indians on the first two trips, they were successful on the third expedition in July 1956. They found the area described by Terry and collected samples of copper minerals, including a plate-sized piece of native copper (Linn et al., 1981a). The samples were shown to Robert (Bob) H. Stewart, the Chief Geologist of the Panama Canal Company (Stewart, 1991; Heckadon-Moreno, 2012a, 2012b, 2012c). Zarn, Pinel and Stewart formed a company with equal shares each, and Stewart joined the next expedition during his vacation in February 1957, when he found the malachite veins seen by Terry, as well as other veins of barites and galena (Heckadon-Moreno, 2012a, 2012b, Stewart, 1957). On 8 March 1957, Stewart and Andres Molina, a Guaymi Indian, found a boulder of massive chalcopyrite in the Río Escopeta. Stewart observed the reddish iron oxide stains on the rocks which gave the Río Colorado (Red River) its name, and followed these up the river to the steep mountain called Cerro Colorado (Red Mountain) (Linn et al., 1981a; Heckadon-Moreno, 2012c). Stewart mapped and sampled the outcrops on a second visit and estimated that the dimensions of low-grade copper sulphide mineralization were 4,000 feet long, 300 feet wide and 1,200 feet deep $(1,220 \mathrm{~m}$ by $91 \mathrm{~m}$ by $365 \mathrm{~m})$, and contained at least 100 million short tons (91 million metric tons) with a grade between 0.05 and $0.5 \% \mathrm{Cu}$ (Stewart, 1957; Texasgulf, 1978; Linn et al., 1981a). Pinel and Zarn obtained an exploration concession and tried for several years to interest mining companies in the project but were unsuccessful and the concession expired (Linn et al., 1981a).

Interest in Cerro Colorado was revived by the discovery of the Petaquilla porphyry copper deposit in 1968. A competitive bid was held by the government and won by Canadian Javelin Lim- ited of Montreal in November 1970, and a 750 $\mathrm{km}^{2}$ exploration concession was awarded to its subsidiary Pavonia S.A. Canadian Javelin carried out 45,000 m of drilling between February 1971 and November 1974. They acted quickly and it is noteworthy that they started drilling within three months of being awarded the contract, especially considering the remoteness and lack of a road, with access by foot and mule. The first holes were drilled with small, portable Winkie drills (Figure 17). Subsequently they bought in bigger diamond drill rigs. Drill hole no. 43 was the first to penetrate the leached capping and to indicate that Cerro Colorado was a major porphyry copper deposit (Linn et al., 1981a). In July 1973 Canadian Javelin announced a maiden resource of 2,000 Mt grading $0.6 \% \mathrm{Cu}$ and plans to develop a mine at a cost of $\$ 560$ million (Hargreaves, 1974). Linn et al. (1991a) stated that the resource was 1.7 billion tonnes at $0.65 \% \mathrm{Cu}$ proven and probable at a cut-off grade of $0.25 \% \mathrm{Cu}$, with 1 billion tonnes estimated to be recoverable by open pit mining. Canadian Javelin formed a consortium with Noranda as the operator, C. Itoh \& Company representing Japanese mining companies and smelters, and British Kynoch Metals. However, Canadian Javelin was unable to reach an agreement about the government's share in the participation of the mine, the government wanting $51 \%$, and the company withdrew from the project in March 1975 and were later paid $\$ 23.6$ million in compensation.

In 1975 the Panamanian Government's new copper corporation CODEMIN (Corporación de Desarrollo Minero Cerro Colorado) negotiated a joint venture with Texasgulf Inc. of the USA, and a contract was signed in February 1976. Texasgulf had 20\% equity of Cerro Colorado and was the project manager while CODEMIN retained 80\% equity on a contributing basis. The project was held by Empresa de Cobre Cerro Colorado S.A. Drilling was carried out in 1975-1976 (12,402 m in 52 holes), a $458 \mathrm{~m}$ long adit was driven for bulk sampling, and a feasibility study was completed in 1978. The Texasgulf study planned for the annual production of $27 \mathrm{Mt}$ of ore and $86 \mathrm{Mt}$ of waste to give 759,000 tonnes of concentrates, with the construction of a port, a smelter and an acid plant. 
In May 1980 Río Tinto Zinc Ltd. (RTZ) of London bought $49 \%$ of the project from Texasgulf and CODEMIN, which reduced CODEMIN's equity to $51 \%$. RTZ carried out $11,562 \mathrm{~m}$ of drilling in 33 holes and made a pre-feasibility study between May 1980 and January 1981. This considered a 40 million tonne-per-year concentrator near the mine site and a 282,000 tonne-per-year smelter at Punta Yurre in the mouth of the Río Santa Lucia on the Pacific. The capital cost was estimated at $\$ 3.2$ billion. Negotiations were in progress for the feasibility study including a pilot plant and a second adit for bulk sampling in the primary zone, when the deaths of two key people halted the project (Gjording, 1991). The first was Ruben Dario Herrera, General Manager of CODEMIN, who died of natural causes. This was followed by the death of General Omar Torrijos in a plane crash on 31 July 1981. Sir Alistair Frame, the CEO of RTZ, was due to meet with Torrijos on the day he died. Negotiations continued but the project had lost its champion in Panama. The project was put on care and maintenance for the next decade from June 1982 until 1993, when RTZ wrote off the carried value of the project, the Empresa de Cobre de Cerro Colorado S.A. was wound up, and the ownership reverted to CODEMIN. The relationship of the project to the Guaymi (Ngäbe Buglé) Indians, on whose land the project is located, throughout this first period of exploration is described by Gjording (1991).

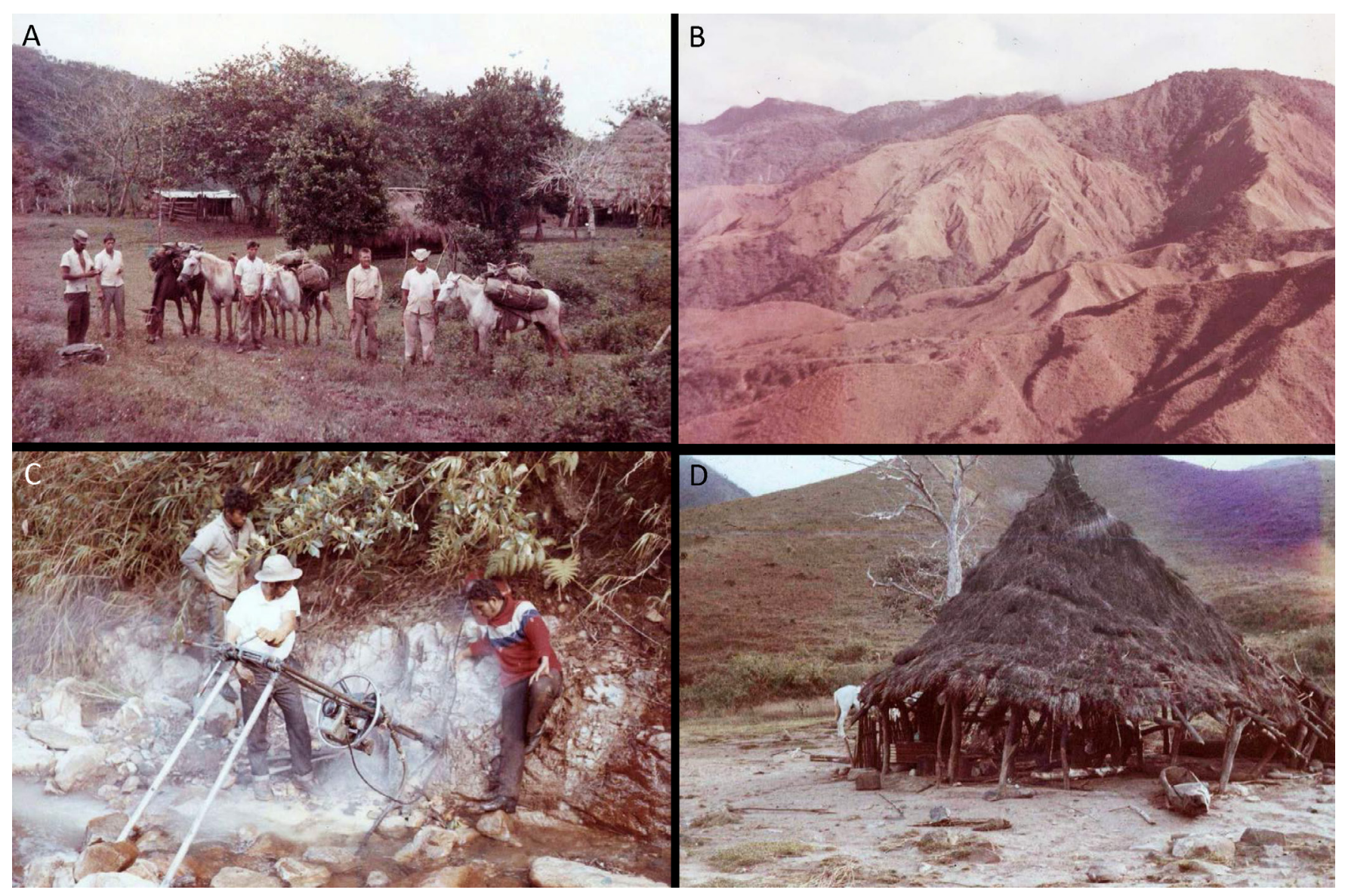

Figure 17 The first drilling of the Cerro Colorado porphyry copper deposit was carried out by Canadian Javelin Limited in 1971,15 years after the deposit was discovered in 1957. A). Geological expedition with mules at Boca del Monte, November 1970. Geologist Tyler Kittredge is second from the right. B) Cerro Colorado in November 1970 before any trails were made. C) Drill hole no. 1 was drilled with a portable Winkie drill by Stan Stewart (driller) in February 1971. D) A native hut or bohio served as the first core shack at Escopeta, February 1971. The photographs are from an album made by the late John C. Doyle, Chief Executive Officer of Canadian Javelin, and now in the possession of his neighbor in Panama, Robert Karman, mine engineer. 
Table 6. The history of the Cerro Colorado copper deposit.

\begin{tabular}{|c|c|}
\hline Year & Owners and Events \\
\hline 1859 & Copper veins reported by the Government of New Granada. \\
\hline 1863 & Report quoted in a book by the British Vice-Consul, Charles Bidwell. \\
\hline 1936 & Robert Terry, Sinclair Oil, discovered copper mineralization. \\
\hline 1956 & Terry's find published in "A Geological Reconnaissance of Panama". \\
\hline 1956 & Joe Zarn, Pablo Pinel and Luis Serrano located Terry's copper discovery. \\
\hline 1957 & Robert H. Stewart discovered Cerro Colorado with Zarn and Pinel. \\
\hline 1969 & Government auction for Cerro Colorado. \\
\hline 1970 & Canadian Javelin Limited, Montreal awarded exploration concession. \\
\hline 1971-1974 & Exploration by Canadian Javelin; 45,000 m drilling in 90 holes. Maiden resource 1973. \\
\hline 1974 & $\begin{array}{l}\text { Canadian Javelin formed a mining consortium with Noranda, C. Itoh \& Co., and British Kynoch } \\
\text { Metals. }\end{array}$ \\
\hline 1975 & Canadian Javelin withdrew after being unable to reach an agreement for the mining rights. \\
\hline 1975 & Government formed Corporacion de Desarollo Minero Cerro Colorado (CODEMIN). \\
\hline 1975-1980 & $\begin{array}{l}\text { Texasgulf, USA-CODEMIN JV 20-80\%. Drilled } 12,402 \mathrm{~m} \text { in } 52 \text { holes, drove } 458 \mathrm{~m} \text { adit, made a } \\
\text { feasibility study. JV company Empresa de Cobre Cerro Colorado SA. }\end{array}$ \\
\hline $1980-1982$ & $\begin{array}{l}\text { Rio Tinto Zinc Ltd., London - CODEMIN JV, 49-51\%. Drilled } 11,562 \mathrm{~m} \text { in } 33 \text { holes, made a pre- } \\
\text { feasibility study. }\end{array}$ \\
\hline 1982-1993 & $\begin{array}{l}\text { RTZ project on care and maintenance. RTZ withdrew 1993. Empresa de Cobre Cerro Colorado SA } \\
\text { wound up. }\end{array}$ \\
\hline 1993 & PanaCobre SA, Panama concession agreement. \\
\hline 1994 & Tiomin Resources Inc. option to acquire PanaCobre. \\
\hline 1996-1997 & PanaCobre drilled 11,696 $\mathrm{m}$ in 69 holes. \\
\hline 1997 & Pre-feasibility study by Kvaernar Metals. \\
\hline 1998 & Feasibility study by Kvaernar Metals. \\
\hline $1998-2001$ & Aur Resources Inc., Toronto, optioned the project. \\
\hline 2001 & Aur became owner of PanaCobre. \\
\hline 2005 & CODEMIN regained project and prepared for a public tender. \\
\hline 2011 & Bid cancelled, concession cancelled and became a Mineral Reserve. \\
\hline 2012 & CODEMIN disbanded. \\
\hline
\end{tabular}

\subsection{PETAQUILLA (COBRE PANAMA) PORPHYRY Cu-Mo-Au-Ag DEPOSIT}

The Petaquilla porphyry deposit, as it was called originally, was discovered by a regional stream sediment geochemistry survey by the United Nations Development Programme in 1968, part of the Phase I Azuero Mining Project carried out between 1966 and 1969 (Table 7; Ferenčić, 1970; Huhta, 1991). Stream sediment sampling of fine grained sediments was carried out in January 1967 and copper mineralization was first discovered in the field by UN geologist Artemio Metti (Ferenčić, 1970). The sampling defined extensive stream sediment anomalies over an area of 623 hectares $\left(6.23 \mathrm{~km}^{2}\right)$ with values of greater than $500 \mathrm{ppm} \mathrm{Cu}$ and $12 \mathrm{ppm} \mathrm{Mo}$, maximum values of 2,000 ppm $\mathrm{Cu}$ and $125 \mathrm{ppm} \mathrm{Mo}$, and an average of $860 \mathrm{ppm}$ $\mathrm{Cu}$ in 33 samples at Botija, and $1042 \mathrm{ppm} \mathrm{Cu}$ in
38 samples at Petaquilla (Kents, 1968). Follow up was not carried out until 13 February 1968 while waiting for cloud-free conditions to take aerial photos to make drainage base maps. Within the first few days in the field, strong indications of porphyry copper type mineralization were found in the Río Botija and in a tributary of the Río Petaquilla. The UN discovery team geologists were Kjell Anzelius (Sweden), D. del Giudice (Italy) and Jussi Huhta (Finland), and the Panamanian technicians were Sres D. Luna, A. Rosas and M. Vega (Huhta, 1991). The discovery was announced at simultaneous press conferences in Panama and New York on 30 April 1968. The discovery was described in three UNDP technical reports (UN, 1968, 1969a; Kents, 1968). The first publication was by Ferencić (1970) and the discovery history is told by Huhta (1991). The original discovery was of the Botija and Petaquilla (Colina) deposits. 


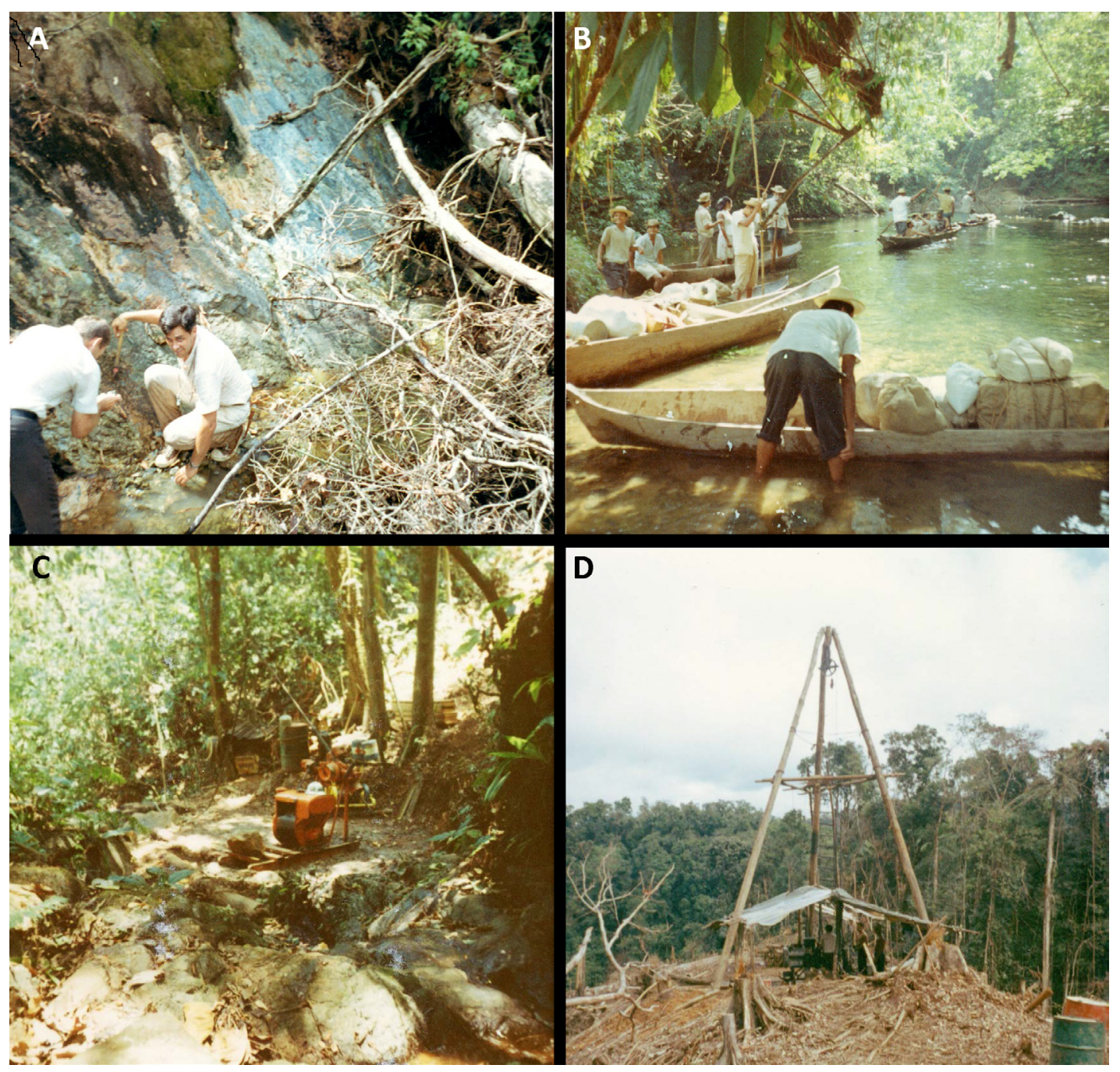

Figure 18 The discovery of the Petaquilla (Cobre Panama) porphyry copper deposit by United Nations' Azuero Mining Project in 1968. A) Jussi Huhta, a Finnish geochemist (facing the camera), one of the discovery team, and an unknown man at the discovery outcrop with blue copper oxides in a stream at the Botija deposit, 1968. B) Field supplies being brought to the project by the River Petaquilla in a fleet of dug-out canoes (cayucos). C) The first drill holes on the Petaquilla project were carried out by UN between October 1968 and June 1969. A Winkie diamond drill was used to drill 27 short holes (total $834 \mathrm{~m}$ ) up to $30 \mathrm{~m}$ deep. D) A helicopter-supported, Boyles BBS-1 diamond drill rig was used by UN to drill 10 deeper holes (total 1,960 m) from drill pads cleared on jungle ridges. Photographs by Jussi Huhta, Finland and published courtesy of his widow Irja Huhta, formerly a chemist with the project. Thanks to Timo Mäki, former Chief Geologist at Inmet's Pyhäsalmi Mine, Finland for tracking down the photos.

Subsequently UNDP carried out 200 line-km of soil sampling which identified several large soil anomalies of greater than $400 \mathrm{ppm} \mathrm{Cu}$ and 25 ppm Mo, and vertical field magnetic surveys which indicated areas of magnetite-destructive alteration and linear zones rich in hydrothermal magnetite, both of which are associated with copper mineralization (Kents, 1968; Awmack, 1992). The UNDP followed up the discovery in 1968-69 with 27 short Winkie drill holes and 10 longer diamond holes (total 2,799 m) on the Botija, Petaquilla (Colina),
Vega (Valle Grande) and Medio areas (Awmack, 1992). The first drill hole, at Botija, returned 53.3 m grading $0.94 \% \mathrm{Cu}$ and $0.028 \%$ Mo from 12.6 $\mathrm{m}$ to $65.9 \mathrm{~m}$ at the end of the hole (Kents, 1968) (Figure 18).

The Panamanian government made an international tender for the project that was won in 1971 by Panama Mineral Resources Development Co. Ltd. (PMRD) of Tokyo, a consortium of three (initially seven) Japanese copper companies whose members were Mitsui Mining and Smelting Co., 
$50 \%$, The Dowa Mining Co., 30\% and Mitsubishi Metal Corp., 20\%. PMRD carried out geological mapping at Botija and Petaquilla (Colina), and a drill program of 14,159 $\mathrm{m}$ in 48 short Winkie holes and 51 long diamond holes at Botija, Petaquilla (Colina), Medio and Vega (Valle Grande) in 19711977. A maiden resource estimate and pre-feasibility study was made on the Petaquilla and Botija deposits in 1977 with a total of $493 \mathrm{Mt}$ grading $0.56 \% \mathrm{Cu}$ and $0.010 \% \mathrm{Mo}$ (cut-off $0.3 \% \mathrm{Cu}$ ), and mineable reserves of $277 \mathrm{Mt}$ grading $0.69 \% \mathrm{Cu}$ (cut-off 0.5\% Cu) (PMRD, 1977). Over the next two years the feasibility study was updated, and unsuccessful negotiations were carried out with the government for terms of production. PMRD dropped the project in 1980 due to low copper prices (Awmack, 1992; Speidel et al., 2001).

\subsection{GERRO GHORGHA PORPHYRY Gu-Au DEPOSIT}

The Cerro Chorcha porphyry $\mathrm{Cu}-\mathrm{Au}$ deposit is located in rugged mountainous terrain in the Central Cordillera of western Panama, $37 \mathrm{~km}$ west of Cerro Colorado (Table 8). Copper mineralization was discovered at Cerro Chorcha by Asarco Exploration Company of Canada Ltd., a subsidiary of Asarco Inc., Tucson, Arizona by a regional stream sediment sampling program in 1969. It is presumed that this program was initiated as a result of the success of the UNDP discovery of Petaquilla in 1968. The Asarco program covered the cordillera west of the UNDP Azuero Project. By 1976 Asarco had outlined porphyry copper mineralization $>0.2 \% \mathrm{Cu}$ by trenching over an area of $600 \mathrm{~m}$ by $300 \mathrm{~m}$ in the Guariviara Zone. Asarco planned to drill in 1976, but was unable to improve the terms of the concession agreement and abandoned the project (Folk, 2005).

\subsection{RÍO PITO, EASTERN SAN BLAS PORPHYRY BELT}

The United Nations Phase II regional stream sediment survey of the southeastern part of San Blas carried out in 1969-1971 found multiple $\mathrm{Cu}, \mathrm{Mo}$ and $\mathrm{Zn}$ anomalies and porphyry $\mathrm{Cu}-\mathrm{Mo}$ prospects in a NW-trending belt $75 \mathrm{~km}$ long. The porphyries were named, from NW to SE, Nava- gandi, Mulatupo, Río Patikan and Río Pito. Río Pito was the strongest anomaly and a follow up exploration program including diamond drilling was carried out in 1970-1972 (UN, 1972a, 1972b, 1972c, 1981). UN made a resource estimate at the Palacios breccia of 297,300 $\mathrm{t}$ grading 2.12 $\mathrm{g} / \mathrm{t} \mathrm{Au}$ and $4.04 \mathrm{~g} / \mathrm{t} \mathrm{Ag}$ based on trenches and drilling. Navagandi, Mulatupo and Río Patikan were described by UN (1972a, 1972b) but no follow up was carried out. Río Pito is close to the Acandi porphyry $\mathrm{Cu}$ prospect in Colombia which was discovered a few years later by the UN and INGEOMINAS in 1975-1976. Several companies carried out reconnaissance visits and exploration of the Río Pito district in the 1980s-2000s, but none have drilled.

\subsection{GANA GOLD DEPOSIT}

The Cana deposit, where gold mining ceased in 1926, was explored for porphyry copper and epithermal gold in the period between 19641996 by several companies including Hochschild in 1964-1966; TexasGulf Western in the 1970s, which drilled 16 holes on Cerro San José; Freeport Exploration Company which drilled 40 holes for 4,600 $\mathrm{m}$ in 1985-1988 at the North Mine, and defined a resource of about 108,000 ounces grading $13.7 \mathrm{~g} / \mathrm{t} \mathrm{Au}$, and Cerro San José (Tippett and Trever, 1989); St. Joe Minerals; and Gold Fields of South Africa which carried out a 1,200 hole soil auguring program in 1992 and defined several soil anomalies $>1$ ppm Au (Table 2). The Panamanian environmental organization ANCON bought the concession from Sociedad de Inversiones IXTAPA S.A. in 1993 with the intention of sterilizing the project. However, it discovered that there were a number of commitments in order to maintain the mining concession valid, and so ANCON optioned the project to Link Mineral Ventures Ltd. of Toronto in 1995-1997, which could earn $80 \%$ by carrying out certain exploration programs and making certain cash payments. Link Mineral Ventures fulfilled these earn-in requirements in 1996, but the joint venture ended in dispute (Durán, 1998). Mining was banned in the Darien National Park in 1996. 
Table 7. The history of the Cobre Panama (Petaquilla) copper mine.

\begin{tabular}{|c|c|}
\hline Year & Owners and Events \\
\hline 1968 & Discovered by UNDP by regional stream sediment geochemistry. \\
\hline 1968-1969 & UNDP drilled 2,799 $\mathrm{m}$ in 37 holes. \\
\hline 1971-1980 & $\begin{array}{l}\text { Panama Mineral Resources Development Co. Ltd. (PMRD), Tokyo, a consortium of } 3 \text { (initially } 7 \text { ) Japanese copper } \\
\text { companies (Mitsui Mining and Smelting Co., Dowa Mining Co., Mitsubishi Metal Corp.). Drilled } 99 \text { holes (14,159 m). } \\
\text { Maiden resource of } 493 \mathrm{Mt} \text { at } 0.56 \% \mathrm{Cu} \text { and } 0.010 \% \mathrm{Mo} \text { at Petaquilla and Botija, and pre-feasibility study } 1977 \text {. }\end{array}$ \\
\hline 1980-1988 & Dormant. \\
\hline 1988 & Staked by GeoRecursos International S.A., Panama. \\
\hline 1990-1992 & Minnova Inc. earned 80\% from GeoRecursos. Carried out lithogeochemical sampling. \\
\hline 1992 & Minnova option to Adrian Resources Inc. to earn 32\% total. Adrian drilled 396 holes $(75,991 \mathrm{~m})$ \\
\hline 1993 & Adrian bought GeoRecursos from MinAmerica Corporation, Panama. Ownership Minnova 48\%, Adrian 52\%. \\
\hline 1993 & Minnova acquired by Metall Mining Corporation. \\
\hline 1993 & Teck Corporation option to earn $26 \%$ from Adrian and became operator. \\
\hline 1994 & $\begin{array}{l}\text { Feasibility study by Kilborn on Petaquilla (Colina) and Botija deposits with mineable reserves of } 579 \mathrm{Mt} \text { at } 0.52 \% \mathrm{Cu} \text {, } \\
0.12 \mathrm{~g} / \mathrm{t} \mathrm{Au}, 0.014 \% \mathrm{MoS} 2\end{array}$ \\
\hline 1995 & Metall Mining became lnmet Mining Corporation. The Panama company remained Minnova (Panama) Inc. \\
\hline 1996 & $\begin{array}{l}\text { Teck drilled } 124 \text { holes }(26,837 \mathrm{~m}) \text {. Feasibility study by Fluor Daniel Wright with mineable reserves of } 1,461 \mathrm{Mt} \text { at } \\
0.493 \% \mathrm{Cu}, 0.11 \mathrm{~g} / \mathrm{t} \mathrm{Au}, 0.015 \% \mathrm{MoS} 2 \text {. }\end{array}$ \\
\hline 1997 & Petaquilla Contract Law No. 9. Holding company Minera Petaquilla S.A. (MPSA) formed. \\
\hline 1998 & $\begin{array}{l}\text { Teck drilled } 43 \text { holes }(8,099 \mathrm{~m}) \text {. Updated feasibility study by Simons with mineable reserves of } 1,115 \mathrm{Mt} \text { at } 0.50 \% \mathrm{Cu} \text {, } \\
0.09 \mathrm{~g} / \mathrm{t} \mathrm{Au}, 0.155 \% \mathrm{MoS} 2 \text {. }\end{array}$ \\
\hline 1998-2003 & Dormant due to low $\mathrm{Cu}$ price. \\
\hline 2003 & Project reactivated. \\
\hline 2005 & $\begin{array}{l}\text { Molejon gold deposit transferred to Petaquilla Minerals Ltd (ex-Adrian Resources). Government accepted the New } \\
\text { Development Plan whereby the start of Molejon Gold infrastructure work was recognized as the Project start under } \\
\text { Petaquilla Law. }\end{array}$ \\
\hline 2007 & Feasibility study updated. \\
\hline 2006-2008 & Petaquilla Copper Ltd drilled 308 holes $(30,383 \mathrm{~m})$. \\
\hline 2007-2018 & MPSA drilled 883 holes $(191,478 \mathrm{~m})$. \\
\hline 2008 & $\begin{array}{l}\text { Teck Cominco (ex-Teck) vested its interest. Ownership became lnmet } 48 \% \text {, Teck Cominco } 26 \% \text {, Petaquilla Copper } \\
\text { (ex-Adrian) } 26 \% \text {. lnmet bought out the partners to own } 100 \% \text {. }\end{array}$ \\
\hline 2008 & Project name changed to Mina de Cobre Panama. Operating company name changed to Minera Panama S.A. (MPSA). \\
\hline 2009 & $\begin{array}{l}\text { Korea Panama Mining Corp. KPMC (LS Nikko Copper Inc. and Korea Resources Corporation, KORES) option to } \\
\text { earn } 20 \% \text {. }\end{array}$ \\
\hline 2010 & lnmet board approved mine construction. \\
\hline 2011 & Balboa Cu-Au discovery. Maiden resource in 2012. \\
\hline 2011 & ESIA (Environmental Social Impact Assessment) approved allowing development to proceed. \\
\hline 2012 & KPMC exercised option and became $20 \%$ shareholder of MPSA. \\
\hline 2012 & lnmet board made production decision. \\
\hline 2012 & Franco Nevada acquired an interest in the precious metals stream. \\
\hline 2013 & Mine construction started. \\
\hline 2013 & First Quantum Minerals Ltd. bought lnmet and acquired $80 \%$ of MPSA. \\
\hline 2014 & First Quantum restarted construction with new plan. \\
\hline 2017 & Exit LS Nikko to give First Quantum $90 \%$ of MPSA, KORES $10 \%$. \\
\hline 2019 & Mine production started. \\
\hline
\end{tabular}

\subsection{RÍO MOGUE GOLD PROSPEGT}

The Río Mogue epithermal gold prospect is located in the Bagre Massif in the headwaters of the Rivers Marea (or Bagre), Mogue and Taimatí in the Darien. Mineralization was discovered at Río Mogue in 1974 probably by the presence of artisanal placer gold mining. It was explored in 1975-1978 by the Dirección General de Recursos Minerales (DGRM) under the Panama Proyecto Experimental. DGRM carried out $994.9 \mathrm{~m}$ of diamond drilling in 31 short holes and 5 longer holes. The best intervals were $37.5 \mathrm{~m}$ at $2.11 \mathrm{~g} / \mathrm{t}$ $\mathrm{Au}$, including $1.5 \mathrm{~m}$ at $36.48 \mathrm{~g} / \mathrm{t} \mathrm{Au} ; 12.5 \mathrm{~m}$ at 4.04 
Table 8. The history of the Cerro Chorcha copper deposit.

\begin{tabular}{|c|c|}
\hline Year & Owners and Events \\
\hline 1969-1976 & $\begin{array}{l}\text { Asarco Exploration Company of Canada Ltd discovered the deposit in a regional stream sediment sampling program. } \\
\text { Outlined } \mathrm{Cu} \text { anomaly by trenching. Could not reach better terms for concession agreement, did not drill } \\
\text { and dropped the project. }\end{array}$ \\
\hline 1990-1992 & Consultores Geologicos S.A. \\
\hline 1993 & Geo-Minas S.A., a JV between Consultores Geologicos and GeoRecursos International S.A., Panama, exploration. \\
\hline 1994-1995 & $\begin{array}{l}\text { Drilled by Ario Resources Ltd. (managed by MK Gold Company) in JV with Geo-Minas. Maiden resource } 1995 \text { of } \\
265.9 \mathrm{Mt} \text { at } 0.493 \% \mathrm{Cu}, 0.057 \mathrm{~g} / \mathrm{t} \mathrm{Au} \text { (cut-off } 0.2 \% \mathrm{Cu} \text { ). }\end{array}$ \\
\hline 1997-1998 & Drilled by Cyprus Minerals. \\
\hline 2005-2008 & Cuprum Resources Corp. (Bellhaven Ventures Inc./ Bellhaven Copper \& Gold Inc.) \\
\hline 2007-2008 & $\begin{array}{l}\text { Drilled by Bellhaven and Dominion Minerals Corp. New resource in } 2008 \text { of } 202 \mathrm{Mt} \text { at } 0.49 \% \mathrm{Cu}, 0.07 \mathrm{~g} / \mathrm{t} \mathrm{Au} \text { (cut- } \\
\text { off } 0.2 \% \mathrm{Cu} \text { ), inc. } 37.4 \mathrm{Mt} \text { at } 0.93 \% \mathrm{Cu}, 0.16 \mathrm{~g} / \mathrm{t} \mathrm{Au} \text { (cut-off } 0.65 \% \mathrm{Cu} \text { ). }\end{array}$ \\
\hline 2009 & Dominion bought Cuprum. \\
\hline 2010 & Supreme Court halted exploration and license expired. \\
\hline
\end{tabular}

$\mathrm{g} / \mathrm{t} \mathrm{Au} ; 13.72 \mathrm{~m}$ at $2.97 \mathrm{~g} / \mathrm{t} \mathrm{Au} ; 14.02 \mathrm{~m}$ at 1.78 $\mathrm{g} / \mathrm{t} \mathrm{Au}$; and $35.05 \mathrm{~m}$ at $1.64 \mathrm{~g} / \mathrm{t} \mathrm{Au}$. The project was later explored in 1996-2000 by Paminexco of Panama and Minera Rayrock, which drilled 10 Winkie holes for $390.8 \mathrm{~m}$.

\subsection{IPETI PORPHYRY Gu-Mo-Au PROSPECT}

The Ipeti porphyry $\mathrm{Cu}-\mathrm{Mo}-\mathrm{Au}$ prospect (also called Río Guayabo, Ambroya, and Majé) is located in the Majé Mountains in the Darien. Mineralization was discovered by a Cu-Mo stream sediment anomaly by the UNDP Phase II survey in 1969-1971 (UN, 1972a, 1972b). The prospect was explored from 1993-1999 by Aluviones de Panama S.A., Panama with International CanAlaska Resources Ltd. and International Taurus Resources Inc., both of Vancouver. They carried out soil surveys, a magnetic survey, and two drill programs with a total of 13 holes for 2,534 $\mathrm{m}$. The soil survey defined an anomaly greater than 200 ppm Cu over an area of 1,200 m by $1,700 \mathrm{~m}$, with an inner zone greater than 500 ppm of $100-400$ $\mathrm{m}$ width, with zones with up to $1,500 \mathrm{ppm} \mathrm{Cu}$. A gold anomaly greater than $50 \mathrm{ppb}$ was coincident with the $200 \mathrm{ppm} \mathrm{Cu}$ anomaly, with values up to 100 to $300 \mathrm{ppb} \mathrm{Au}$. The best drill result was 160.7 $\mathrm{m}$ grading $0.20 \% \mathrm{Cu}$ and $0.176 \mathrm{~g} / \mathrm{t} \mathrm{Au}$, including $29.5 \mathrm{~m}$ grading $0.33 \% \mathrm{Cu}$ and $0.269 \mathrm{~g} / \mathrm{t} \mathrm{Au}$.

\subsection{GERRO QUEMA EPITHERMAL Au-Gu DEPOSIT}

The Cerro Quema deposit is a high sulphidation epithermal gold-copper deposit. A gold oxide zone with vuggy silica and advanced argillic alteration overlies a sulphide zone with enargite-chalcopyrite-pyrite and supergene chalcocite enrichment. Cerro Quema was identified in 1967 by a single copper anomaly in the Phase I regional stream sediment survey carried out by the United Nations (UN, 1969). Chalcocite was found in boulders in a stream draining Cerro Quemita but no outcropping mineralization was found, and the gold potential was not recognized for another two decades until 1986.

The UN program detected three other copper anomalies in the western part of the Azuero belt which were followed up in the Phase II program (UN, 1972b) at Los Nopos, Iguana and Quebrada Barro. Stream sediment samples at Los Nopos gave up to $440 \mathrm{ppm} \mathrm{Cu}$, rock samples up to $2.2 \% \mathrm{Cu}$ and 1,200 ppm Zn, and soil samples were anomalous in $\mathrm{Cu}-\mathrm{Mo}$, associated with silicification. The Quebrada Barro prospect was followed up with 9 short drill holes $(314.4 \mathrm{~m})$ with intersections that included $5.9 \mathrm{~m}$ at $1.08 \% \mathrm{Cu}, 0.90 \mathrm{~g} / \mathrm{t} \mathrm{Au}$ and 140 $\mathrm{ppm} \mathrm{Mo}$, and $4.37 \mathrm{~m}$ at $0.46 \% \mathrm{Cu}, 1.3 \mathrm{~g} / \mathrm{t} \mathrm{Au}$, $4.0 \mathrm{~g} / \mathrm{t} \mathrm{Ag}$ and $51 \mathrm{ppm}$ Mo (UN, 1972b). They were interpreted at the time as contact metasomatic deposits and have been reinterpreted by the author as high sulphidation epithermal $\mathrm{Cu}-\mathrm{Au}$ sulfide deposits.

\subsection{EL GALLO Au-Ag-Pb MINE}

The El Gallo gold mine at Las Minas (Herrera) is described as a $16^{\text {th }}$ century Spanish mine which was mined in a glory hole or open pit about 45 
$\mathrm{m}$ in diameter on the hill-top (Riddell, 1927). It was mined for $\mathrm{Au}-\mathrm{Ag}-\mathrm{Pb}$ in the late $19^{\text {th }}$ century (Posada, 1898; Oller, 1933). The Panama Corporation Ltd. explored it in the 1920s by extending one of the five tunnels further into the hill (Riddell, 1927). The tunnels were reopened by the UNDP project in 1967-1969, which found only galena (del Giudice and Recchi, 1969).

\subsection{HEAVY MINERAL SANDS}

Shallow marine placer deposits of heavy mineral sands occur over a distance of $60 \mathrm{~km}$ between Punta Chamé and Boca del Río Hato on the Pacific coast in Panama West and Coclé provinces. They had historical estimated "proven reserves" (probably equivalent to inferred resources) of 3.0 Mt (del Giudice and Recchi, 1969; Quirós, 1975). The shallow marine deposits off Gorgona Beach were exploited by dredging in 1971-1972 by Hierro Panama S.A., a 50-50 joint venture between Sumitomo Corporation of Japan and Minera Chame S.A. of Panama (Redwood, 2020a). The black sands were concentrated by electromagnets and stockpiled on Bona Island, where they were loaded onto bulk carriers for export to Japan. A total of 200,000 tonnes of concentrates of magnetite and ilmenite grading $64 \% \mathrm{Fe}$ and $6 \% \mathrm{TiO}_{2}$ were produced and 75,000 tonnes were exported in three shipments. An accident occurred on the fourth shipment when the ship was blown against the loading dock and badly damaged it, and the operation was abandoned.

\section{Modern gold-copper exploration and mining}

\subsection{OVERVIEW}

The Panamanian Government's DGRM continued to carry out several regional exploration programs in the 1980s with funding by international agencies. These programs were the Azuero Peninsula Project of mapping and geochemistry (1982); the Radioactive Minerals Project with the International Atomic Energy Agency (1985); the Remote Sensing Project (1985-1987); and the Mineral Inventory for the Evaluation of Mineral Resources in Three Areas of Panama Project (1987-1990), which was funded by the Interamerican Development Bank (IDB) and was carried out under contract by Swedish Geological International (SGI), part of the Swedish Geological Survey (SGAB) (SGI, 1991a, 1991b). A total area of $50,197 \mathrm{~km}^{2}$, or about two-thirds of the country, was explored by stream sediment surveys between 1967-1990 (Nelson, 1995).

The success of the copper and gold exploration programs by UNDP, IDB, SGI and the Panamanian Government between 1965-1990 encouraged private companies to explore and led to a boom in gold and copper exploration by national and foreign companies from 1985 to the 2000 s, stimulated by the rise in the gold price in the 1980s. The first foreign company was Freeport Exploration Company in 1985, a subsidiary of Freeport McMoRan Inc. of New Orleans, which explored in the Central Veraguas gold district and Cana (Tippett and Trever, 1989), following their discovery of the Ertzberg-Grasberg copper-gold skarn-porphyry deposits in similar but more extreme climate and terrain in Indonesia (Wilson, 1981; Mealey, 1996). Two gold mines were put in operation in Central Veraguas in the 1990s at Remance (1990-1998) and Santa Rosa (1995-1999), the first gold mines in Panama in more than 50 years. There was renewed interest in the evaluation of the porphyry copper deposits at Petaquilla (1990), Cerro Colorado (1993), Cerro Chorcha (1994), Palmilla (1993) and Ipeti (1993) with drilling and evaluation programs at all of them (Figure 16). The major political events during this period were the US invasion in 1989, and the return of the Panama Canal by the US to Panama in 1999.

Significant new discoveries during this period were the discovery of gold at Cerro Quema in 1989, which opened up a new gold belt in southern Azuero; the Cerro Caballo gold deposit in the 1980s; the Río Liri gold deposit in 1988; the Cerro Lloron gold prospect in 1988; the Molejon 
gold deposit in 1992; and the concealed Balboa copper-gold deposit in the Cobre Panama district in 2011 (Figure 16).

The exploration boom wound down in the late 2000s and there has been a moratorium on new concessions for the past decade while waiting for a new mining law. As a result, there has been no green-fields exploration. However, there has been a policy of focused mine developments at the Molejon gold mine (2009-2014), the Cobre Panama copper mine which started production in 2019, the Santa Rosa gold mine which is preparing to re-start production in 2020, and the Cerro Quema gold deposit which applied for an environmental permit to build a gold mine in 2017.

The start of copper production at the world class Cobre Panama mine in 2019 is transforming Panama into a major copper exporter. Once full production of 350,000 tonnes of copper per year is reached, Panama will rank in fourth place in copper production in Latin America after Chile, Peru and Mexico, and ahead of Brazil, and $14^{\text {th }}$ place worldwide.

\subsection{GERRO GOLORADO GOPPER PROJEGT}

Following a decade of inactivity and the withdrawal of RTZ from the Cerro Colorado project in 1993, a private Panamanian company called PanaCobre S.A. obtained a concession agreement with CODEMIN in the same year. It then signed an option agreement with Tiomin Resources Inc. of Toronto in August 1994 by which it could acquire $100 \%$ of PanaCobre S.A. In March 1996 it received final approval from the Panamanian Government for the project to be developed. PanaCobre carried out 11,696 $\mathrm{m}$ of diamond drilling in 69 holes in 1996-1997. A pre-feasibility study was completed by Kvaerner Metals in 1997 and a feasibility study in 1998 (Kvaerner Metals, 1997, 1998). In May 1998 the government approved an extension to the contract providing for a suspension of obligations to make a production decision and related payments for up to five years, or when the copper price exceeded $\$ 1.18 / \mathrm{lb}$ for 90 days.

The 1998 mineral resource estimate contained 1,754.7 Mt at $0.637 \% \mathrm{Cu}$ with $11.2 \mathrm{Mt}$ of con- tained copper at $0.4 \% \mathrm{Cu}$ cut-off (measured, indicated and inferred resource), including 149 Mt at $0.69 \% \mathrm{Cu}$ in the supergene zone (Kvaerner Metals, 1998). These were contained within a global resource (at a $\% \%$ Cu cut-off) of 3,539.2 Mt at $0.417 \% \mathrm{Cu}$ containing $14.8 \mathrm{Mt}$ of copper. The resource has credits for $\mathrm{Mo}, \mathrm{Ag}$ and $\mathrm{Au}$ which were given in an earlier resource estimate as $0.006 \%$ Mo (212,000 t Mo), $4.1 \mathrm{~g} / \mathrm{t} \mathrm{Ag} \mathrm{(14,500} \mathrm{t} \mathrm{Ag)} \mathrm{and}$ $0.07 \mathrm{~g} / \mathrm{t} \mathrm{Au}(248 \mathrm{t} \mathrm{Au})(0 \% \mathrm{Cu}$ cutoff) (Linn et al., 1981b). The proposed development was for a start-up operation for the extraction of supergene copper by an SX-EW process with 61.104 Mt of proven and probable ore reserves with grades of $0.459 \% \mathrm{Cu}$ soluble and $0.730 \% \mathrm{Cu}$ total. This was envisaged as leading to stage two development of the much larger primary copper resource, with a 100,000 tpd conventional milling operation to produce 182,000 to 227,000 tonnes per year of $\mathrm{Cu}$ in concentrates (Kvaerner Metals, 1998).

Tiomin gave Aur Resources Inc. of Toronto the option to acquire $100 \%$ of PanaCobre as consideration for a US $\$ 2$ million loan to Tiomin on 24 December 1998. Tiomin transferred its interest in PanaCobre to Aur in full satisfaction of the loan on 23 February 2001. Aur did not carry out any new work on the project, and its agreement with the government expired in February 2005.

Having regained control of the project in 2005, CODEMIN and made preparations for a public tender to develop the project. However, the planned bid was suspended in February 2011 following protests by the Ngäbe Buglé Indians. The concession was cancelled and became a Mineral Reserve, and CODEMIN was disbanded in 2012.

\subsection{GOBRE PANAMA (PETAQUILLA) GOPPER MINE}

After more than a decade lying dormant since the Japanese consortium left the project, exploration started again at Petaquilla in 1990 (Table 7). The project was explored from 1990-1992 by Minnova Inc. of Toronto with $80 \%$ and Georecursos International S.A. of Panama with 20\%. Exploration included lithogeochemical sampling. From 1992-1998 the partnership was Minnova Inc. with 48\%, which subsequently became Metall Mining 
Corporation (1993) and then Inmet Mining Corporation (1995), and Adrian Resources Ltd. of Vancouver with $32 \%$ initially, and then $52 \%$ after it bought Georecursos. Adrian carried out soil grid sampling, geological mapping, ground magnetic surveys and drilled 396 diamond drill holes totaling $75,991 \mathrm{~m}$. All samples were analyzed for $\mathrm{Cu}, \mathrm{Mo}, \mathrm{Au}$ and $\mathrm{Ag}$, the first time that precious metals were evaluated (Awmack, 1992). In 1994, Adrian granted Teck Cominco Ltd. of Vancouver an option to earn half of its interest, equal to a $26 \%$ total interest, by completing a feasibility study, and it became the operator. Teck drilled 91 infill and 33 condemnation holes for 26,837 $\mathrm{m}$ in 1996 and completed a feasibility study. The study was updated in 1997-1998 with 43 infill and metallurgical holes for 8,099 m. However, the project was put on hold in 1998 due to low copper prices (Speidel et al., 2001; Gray et al., 2019).

After five years, the Petaquilla project was reactivated for the third time in 2003 (Gray et al., 2019). The first step was the spin-off of the Molejon gold deposit into Petaquilla Minerals Ltd., formerly called Adrian Resources, in 2005. Petaquilla Copper Ltd., a subsidiary of Petaquilla Minerals, carried out drilling of 308 holes $(30,383 \mathrm{~m})$ of the copper deposits in 2006-2008. Inmet consolidated $100 \%$ ownership of the Petaquilla deposit by buying Petaquilla Copper's and Teck's interests in 2008, changed the name of the project to Mina de Cobre Panama and the name of the operating company to Minera Panama S.A. (MPSA). The following year, Inmet brought in Korea Panama Mining Corp., a joint venture of LS Nikko Copper Inc. and Korea Resources Corporation (KORES), as a 20\% partner. Between 2007-2018, MPSA drilled a total of 883 infill, exploration, condemnation and metallurgical holes for 191,478 $\mathrm{m}$ (Figure 19). The total drilling between 1968 and 2018 was $348,775 \mathrm{~m}$ in 1,813 holes (Gray et al., 2019).

The discovery of the concealed, high grade Balboa $\mathrm{Cu}-\mathrm{Au}$ deposit was made in 2011 (Inmet press releases 8 March 2011, 31 May 2011; Inmet, 2011). The initial drill holes included intersections of $382.9 \mathrm{~m}$ at $0.58 \% \mathrm{Cu}$ and $0.22 \mathrm{~g} / \mathrm{t} \mathrm{Au}$, includ- ing $101.4 \mathrm{~m}$ at $1.24 \% \mathrm{Cu}$ and $0.52 \mathrm{~g} / \mathrm{t} \mathrm{Au}$; and $221.8 \mathrm{~m}$ at $1.41 \% \mathrm{Cu}$ and $1.29 \mathrm{~g} / \mathrm{t} \mathrm{Au}$, including $124.3 \mathrm{~m}$ at $2.32 \% \mathrm{Cu}$ and $2.28 \mathrm{~g} / \mathrm{t} \mathrm{Au}$. A maiden resource was completed in 2012 of 602 Mt grading $0.36 \% \mathrm{Cu}$ and $0.10 \mathrm{~g} / \mathrm{t} \mathrm{Au}$ indicated resource plus $301 \mathrm{Mt}$ grading $0.31 \% \mathrm{Cu}$ and $0.08 \mathrm{~g} / \mathrm{t} \mathrm{Au}$ inferred resource, at a cut-off grade of $0.15 \% \mathrm{Cu}$ (Inmet press release 5 March 2012). Balboa was discovered by drilling an area of low resistivity west of the Colina deposit that encountered an orebody inclined at about $30^{\circ} \mathrm{NW}$ beneath barren andesites. The surface outcrop at Cuatro Crestas had been previously drilled by shallow holes with low grade results. It is a salutary exploration lesson to discover a concealed, high grade orebody in the middle of a well-explored deposit after more than 40 years of exploration. All of the other porphyry deposits outcrop and were discovered by a combination of stream sediment, soil and rock geochemistry.

Inmet started construction of a copper mine in 2013 with production planned for late 2015. The royalty company Franco Nevada Ltd. of Toronto acquired an interest in the gold and silver stream in 2012 for $\$ 1$ billion in project financing, an innovative way to fund part of the development cost without resorting to equity or debt finance. First Quantum Minerals Ltd. of Vancouver bought Inmet with its $80 \%$ interest in MPSA in 2013. Subsequently, First Quantum bought LS Nikko's $10 \%$ share of MPSA in 2017 to give it $90 \%$, with the remaining $10 \%$ held by Korea Resources Corporation (KORES). First Quantum restarted construction of the mine with its own plan in 2014, and the mine started production in 2019.

The Cobre Panama deposit contains measured and indicated mineral resources of 3,657 Mt grading $0.37 \% \mathrm{Cu}, 0.07 \mathrm{~g} / \mathrm{t} \mathrm{Au}, 1.34 \mathrm{~g} / \mathrm{t} \mathrm{Ag}$ and $0.006 \%$ Mo in seven deposits, plus inferred mineral resources of 1,097 $\mathrm{Mt}$ at $0.26 \% \mathrm{Cu}, 0.04 \mathrm{~g} / \mathrm{t} \mathrm{Au}$, $1.09 \mathrm{~g} / \mathrm{t} \mathrm{Ag}$ and $0.005 \%$ Mo at a cut-off grade of $0.15 \% \mathrm{Cu}$ (Gray et al., 2019). The total contained metal is $16.38 \mathrm{Mt}$ of copper, $300 \mathrm{t}$ of gold, 6,100 $\mathrm{t}$ of silver and 274,000 $\mathrm{t}$ of molybdenum. The resources include proven and probable mineral reserves of 3,143.7 Mt grading $0.38 \% \mathrm{Cu}, 0.07$ 
$\mathrm{g} / \mathrm{t} \mathrm{Au}, 1.37 \mathrm{~g} / \mathrm{t} \mathrm{Ag}$ and $59.38 \mathrm{ppm}$ Mo. These are based on prices of $\$ 3.00 / \mathrm{t} \mathrm{Cu}, \$ 1,200 / \mathrm{oz} \mathrm{Au}$ and $\$ 16 / \mathrm{oz} \mathrm{Ag}$. The reserves are in five planned open pits at Botija, La Colina (formerly called Petaquilla) with Medio, Valle Grande, Balboa, and Botija Abajo with Brazo. The first deposit to be mined is Botija. The plant capacity started at 47 Mt per year in 2019 with plans to increase to 100 Mt per year in 2023 (Figure 20). Average annual copper in concentrates production is $310,000 \mathrm{t}$ of $\mathrm{Cu}$ rising to 377,000 tonnes per year, plus average annual by-products of $107,000 \mathrm{oz}(3,328 \mathrm{~kg}) \mathrm{Au}$, 1.7 Moz (52.9 t) Ag and 2,717 t Mo. The mine life is 35 years to 2054 (Grey et al., 2019).

\subsection{PALMILLA PORPHYRY Gu-Au PROSPEGT}

The Palmilla porphyry $\mathrm{Cu}-\mathrm{Au}$ prospect, located northwest of Cobre Panama, was discovered during the follow up phase of the UN regional exploration program in 1969. It was drilled by Adrian Resources and Madison Enterprises Corporation in 1993-1996, and by Petaquilla Minerals Ltd. in 2011-2013, with a total of 13,136 m of diamond drilling in 60 holes. This gave a measured and indicated resource of $27 \mathrm{Mt}$ at $0.24 \% \mathrm{Cu}, 0.59 \mathrm{~g} / \mathrm{t} \mathrm{Au}$ and $0.87 \mathrm{~g} / \mathrm{t} \mathrm{Ag}$, and an inferred resource of 11 Mt at $0.22 \% \mathrm{Cu}, 0.40 \mathrm{~g} / \mathrm{t} \mathrm{Au}$ and $0.67 \mathrm{~g} / \mathrm{t} \mathrm{Ag}$, at a cut-off $0.35 \mathrm{~g} / \mathrm{t}$ Au equivalent (Camus, 2013).
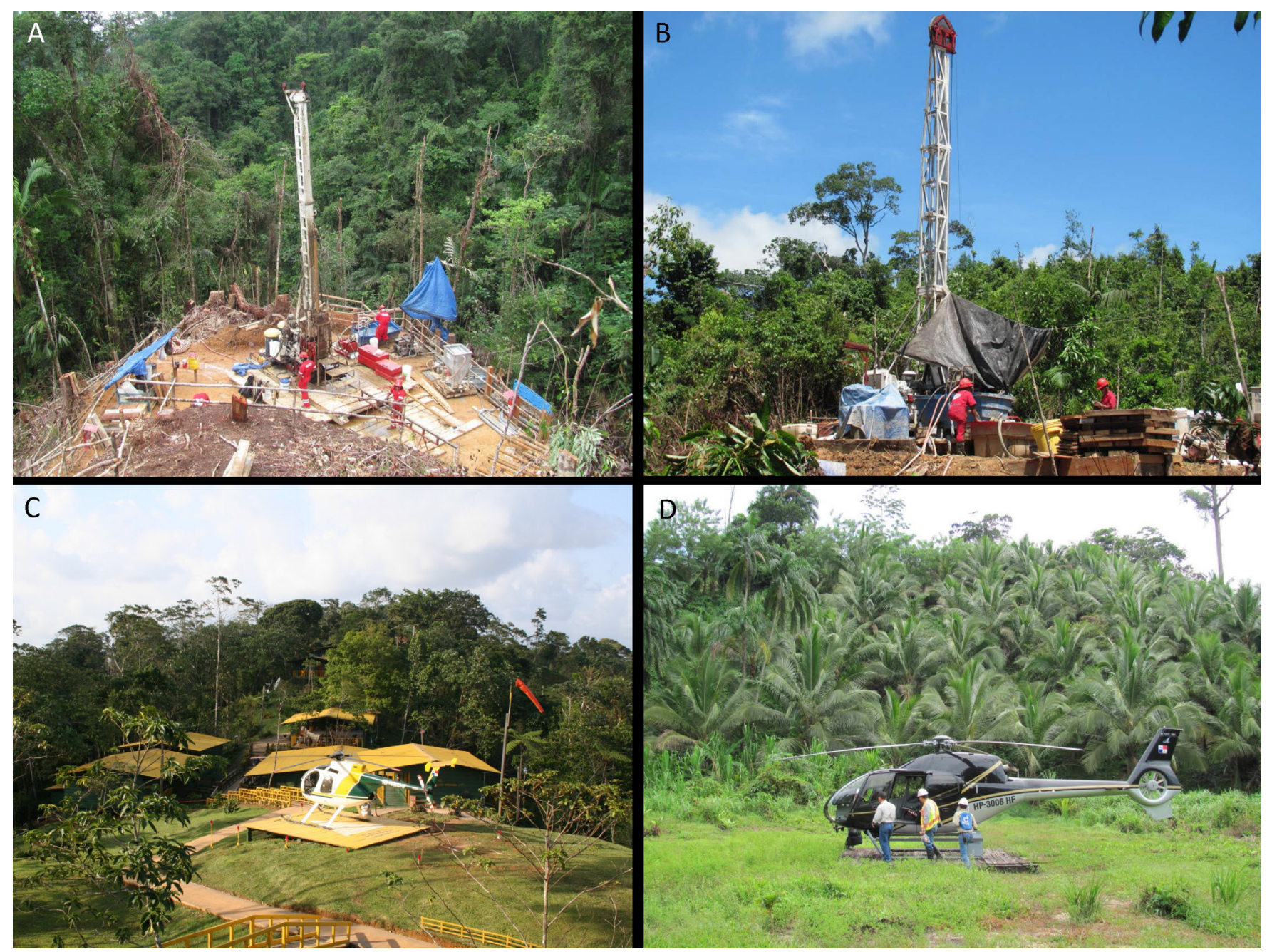

Figure 19 Exploration at Cobre Panama by Minera Panama S.A. in 2007-2011. A) Diamond drilling at Botija Abajo with a Boart-Longyear LF-70 rig, June 2010. B) Diamond drilling at Balboa with a Boart-Longyear Fly 38 rig, October 2011. Both drills were portable and all of the drilling was carried out by helicopter slinging. C) Colina camp with a Hughes 500 helicopter, 18 March 2007. D) Eurocopter Colibri helicopter pickup of a community relations field party at Rio Caimito, October 2010. (Photographs A, B and D by Colin Burge. Photograph C by Stewart Redwood). 


\subsection{MOLEJON GOLD MINE}

The Molejon deposit is a low sulphidation epithermal vein deposit located about $2 \mathrm{~km}$ southwest of the Brazo porphyry copper deposit in the Cobre Panama district. It was discovered by Minnova (Inmet Mining) in 1992 in the course of district-scale exploration around Petaquilla using regional rock geochemistry (Table 9; Speidel et al., 2001). This geochemical exploration technique involved low density rock-grab sampling of 3-4 samples per square $\mathrm{km}$ of the most altered and mineralized rocks found, and was surprisingly effective. The Molejon prospect was drilled by their partner Adrian Resources in 1994-1995, which defined a maiden resource of $8 \mathrm{Mt}$ grading $2.2 \mathrm{~g} / \mathrm{t} \mathrm{Au}$, containing 570,000 oz Au, at a cutoff of $0.48 \mathrm{~g} / \mathrm{t} \mathrm{Au}$, in 1996 (Inmet Annual Report, 1996). In 2005 Inmet and Teck transferred their interest in the project to Petaquilla Gold S.A., a

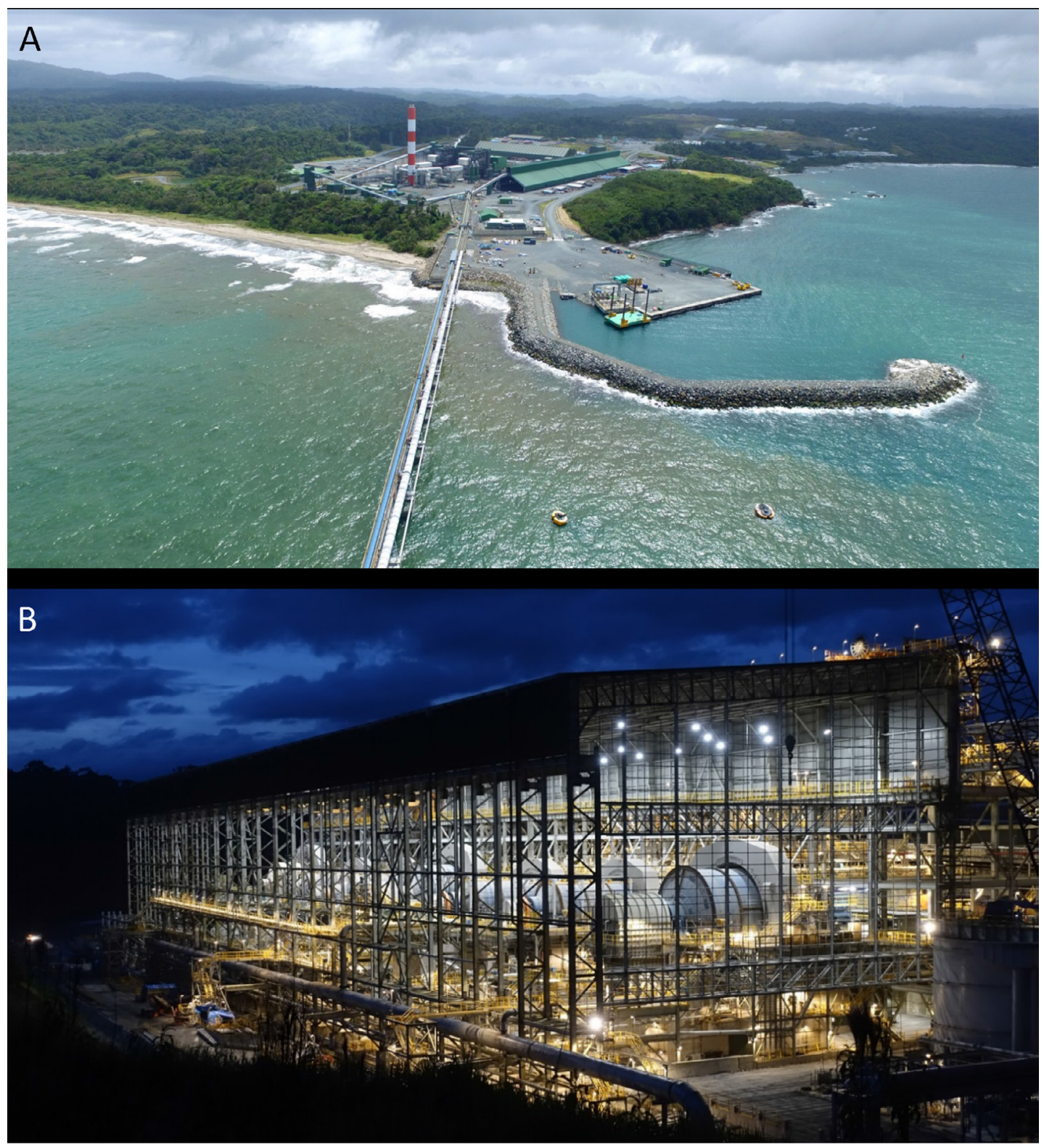

Figure 20 The Cobre Panama mine 2019-2020. A) The ore and coal port and 300 MW thermal power plant at Punta Rincon. B) The eight mills consisting of three $28 \mathrm{MW}$ SAG mills, four $16.5 \mathrm{MW}$ ball mills and one $22 \mathrm{MW}$ ball mill have a design capacity of 274,000 tonnes of ore per day and 85 million tonnes per year, and is the second largest mill in the world. (Photographs First Quantum Minerals Ltd. website). 
Table 9. The history of the Molejon gold mine.

\begin{tabular}{|c|l|}
\hline Year & \multicolumn{1}{c|}{ Owners and Events } \\
\hline 1992 & Discovered by Minnova (later Inmet Mining Corp.) by reconnaissance rock geochemistry. \\
\hline $1994-1995$ & Drilled by Adrian Resources Ltd. \\
\hline 1996 & Maiden resource. \\
2003 & Petaquilla Minerals Ltd. (ex-Adrian Resources) reactivated project, new resource 2005. \\
\hline 2005 & Petaquilla Gold S.A., owned by Petaquilla Minerals, got 100\% from lnmet and Teck. \\
$2006-2009$ & Mine construction. \\
\hline 2014 & Mining. \\
\hline
\end{tabular}

subsidiary of Petaquilla Minerals Ltd., Vancouver (ex-Adrian Resources Ltd.), which started mine construction in 2006. It mined the deposit by open pit from 2009-2014 and produced 231,540 ounces $(7,202 \mathrm{~kg})$ of gold, with byproduct silver. The ore was processed by grinding and gold was recovered in a carbon-in-pulp plant with 2,200 tpd capacity, later expanded to 3,500 tpd (Figures 21 C and 21D). Low grade material containing 152,000 ounces $(4,728 \mathrm{~kg})$ of gold was stockpiled for a planned heap leach plant. The measured and indicated resources were $31.6 \mathrm{Mt}$ at $0.80 \mathrm{~g} / \mathrm{t} \mathrm{Au}(25,424 \mathrm{~kg}$ or 817,400 oz.) and $1.74 \mathrm{~g} / \mathrm{t} \mathrm{Ag}(43,545 \mathrm{~kg}$ or $1.4 \mathrm{Moz})$ at a cutoff of $0.2 \mathrm{~g} / \mathrm{t} \mathrm{Au}$, plus inferred resources of 3.3 Mt at $0.35 \mathrm{~g} / \mathrm{t} \mathrm{Au}$ and $1.05 \mathrm{~g} / \mathrm{t} \mathrm{Ag}$ (Archibald $e t$ al., 2012). Proven and probable reserves were 15.3 Mt at $1.31 \mathrm{~g} / \mathrm{t} \mathrm{Au}(20,008 \mathrm{~kg}$ or 643,266 ounces) and $2.1 \mathrm{~g} / \mathrm{t} \mathrm{Ag}(1.0 \mathrm{Moz})$, at a cut-off of $0.2 \mathrm{~g} / \mathrm{t} \mathrm{Au}$ (Archibald et al., 2012).

\subsection{GERRO QUEMA Au-Gu DEPOSIT}

The gold potential of the Cerro Quema copper anomaly, discovered by UNDP in the Azuero Mining Project in 1967, was not recognized until 1986 when Compañía de Exploración Minera, S. A. (CEMSA) of Panama visited the area and obtained up to $5.2 \mathrm{~g} / \mathrm{t} \mathrm{Au}$ in rock chip samples (Table 10). It was joint ventured to Cyprus Minerals Company of Englewood, Colorado in 1990-1994, which drilled and reported a maiden resource of $10 \mathrm{Mt}$ grading $1.26 \mathrm{~g} / \mathrm{t}$ Au (Torrey and Keenan, 1994). Several companies have since evaluated the project and made resource estimates and feasibility studies, the most recent being a pre-feasibility study by Tortelli et al. (2014). Campbell Resources Inc. of Montreal started construction of a gold mine in 1997 but stopped the same year due to the drop in the gold price. Pershimco Resources Inc. of RouynNoranda, Quebec applied for an environmental license to build an open pit, oxide gold mine in 2016, the outcome of which is still awaited. The project has been owned since 2016 by Orla Mining Ltd. of Vancouver. The total (measured, indicated and inferred) oxide resource is $24.6 \mathrm{Mt}$ at 0.71 $\mathrm{g} / \mathrm{t} \mathrm{Au}$ and $0.04 \% \mathrm{Cu}$ plus $11.4 \mathrm{Mt}$ at $0.41 \mathrm{~g} / \mathrm{t}$ $\mathrm{Au}$ and $0.31 \% \mathrm{Cu}$ in sulfides, containing a total of $22.1 \mathrm{t}(0.71 \mathrm{Moz}) \mathrm{Au}$ and 38,100 t Cu, which occurs in four zones, La Pava, Quema, Quemita and La Mesita (Tortelli et al., 2014). This is based on 641 drill holes totaling $63,341.8 \mathrm{~m}$. The proven and probable reserves in oxides at La Pava and Quema are $19.71 \mathrm{Mt}$ at $0.77 \mathrm{~g} / \mathrm{t} \mathrm{Au}$ containing $15.1 \mathrm{t}$ (488,000 ounces), with the majority in La Pava (Tortelli et al., 2014).

\subsection{GERRO LLORÓN GOLD PROSPEGT}

Cerro Llorón (or Cerro Pelado) is a high sulphidation epithermal gold prospect hosted by vuggy silica alteration in tuffs near the NE margin of the El Valle summit caldera. Gold mineralization was discovered by stream sediment anomalies in a regional exploration program carried out by Swedish Geological International A.B. in 19881990 (SGI, 1991a, 1991b). It was explored by Rayrock Resources Inc. of Toronto in 1995-1997 which drilled 6 holes for $848 \mathrm{~m}$ in 1996. The best results were $142 \mathrm{~m}$ at $0.5 \mathrm{~g} / \mathrm{t} \mathrm{Au}$ and $50 \mathrm{~m}$ at 0.93 $\mathrm{g} / \mathrm{t}$ Au in vuggy silica. 
Table 10. The history of the Cerro Quema gold deposit.

\begin{tabular}{|c|l|}
\hline $\begin{array}{c}\text { Year } \\
1967\end{array}$ & \multicolumn{1}{c}{ Owners and Events } \\
\hline $1988-1989$ & CompP regional exploration de Exploración Minera, S.A. (CEMSA), Panama discovered Au. \\
\hline $1990-1994$ & Cyprus Amax Minerals Company JV with CEMSA (Minera Cerro Quema S.A.) drilled. Maiden resource 1994. \\
$1996-2001$ & Campbell Resources Inc. \\
1997 & Campbell started mine construction but stopped (low Au price). \\
2001 & Carena Equities Corporation, Panama. \\
\hline $2002-2006$ & JV with RNC Resources Ltd. \\
\hline 2006 & JV with Yamana Gold Inc. \\
$2006-2007$ & JV with Glencairn Gold Corp./ Central Sun Mining Inc. \\
$2007-2010$ & JV with Bellhaven Copper \& Gold Inc. \\
$2010-2016$ & Pershimco Resources Inc. bought Carena. \\
2016 & Pershimco applied for environmental license to build a mine. \\
$2016-2020$ & Orla Mining Ltd exploration and await environmental license. \\
\hline
\end{tabular}

\subsection{GERRO NEGRO GOLD PROSPECT}

The Cerro Negro epithermal gold prospect, located about $20 \mathrm{~km}$ NW of Chitré (Herrera), was explored by several companies from 1986 to 1993 . These were Tenneco Minerals Company (Minera Orion Ltda) of Lakewood, Colorado in 1986-1988, Echo Bay Mines Ltd. of Toronto in 1988-1989, and Noranda Inc. of Toronto in 1992-1993. Tenneco/Echo Bay drilled 24 holes for 1,873 $\mathrm{m}$ with short, high grade intercepts in the Paris Sur area such as $0.6 \mathrm{~m}$ at $47.2 \mathrm{~g} / \mathrm{t}$ Au and $16.6 \mathrm{~g} / \mathrm{t} \mathrm{Ag}, 1.0 \mathrm{~m}$ at $23.3 \mathrm{~g} / \mathrm{t} \mathrm{Au}$ and $28.2 \mathrm{~g} / \mathrm{t} \mathrm{Ag}$, and $1.2 \mathrm{~m}$ at $4.9 \mathrm{~g} / \mathrm{t} \mathrm{Au}$ and $12.6 \mathrm{~g} / \mathrm{t} \mathrm{Ag}$.

\subsection{LOS HATILLOS GOLD DEPOSIT}

The Los Hatillos veins were evaluated by UNDP in 1967-1969 which reported reserves of 30,000 tons grading $12.5 \mathrm{~g} / \mathrm{t} \mathrm{Au}, 21.6 \mathrm{~g} / \mathrm{t} \mathrm{Ag}, 2.49 \% \mathrm{~Pb}, 3.85 \%$ $\mathrm{Zn}$ and $0.14 \% \mathrm{Cu}$ on La Blanca Vein (Wleklinski, 1969; Folk, 2004b). Subsequently it was explored by the Dirección General de Recursos Minerales in 1978, Duval Corporation in 1985, Freeport in 1988, Bellhaven in 2004 (Folk, 2004b) and Golden Cross Resources of Australia in 2008.

\subsection{REMANGE GOLD MINE}

After almost 60 years, the Remance gold mine was operated again from 1990-1998 by Minera Remance
S.A., a company owned by the Ganoza mining family of Peru, in an operating contract with Transworld Explorations S.A. of Panama (Figure 21A; Table 11). Over this period the mine produced about 88,000 ounces $(2,737 \mathrm{~kg})$ of gold at a head grade of $6.0 \mathrm{~g} / \mathrm{t}$ which was processed in a 100 tpd CIP plant, later expanded to 300 tpd. Reserves in 1993 were 500,000 tonnes at $6.0 \mathrm{~g} / \mathrm{t}$ $\mathrm{Au}(2,986 \mathrm{~kg}$ or 96,000 ounces). Several companies carried out exploration drilling for bulk mineable targets as well as veins including Cyprus Minerals in the 1990s, Northfield Minerals Inc. of Toronto in 1995-1996, Héron Exploration Inc. of Quebec City in 1998-2000, and Pacific Rim Mining Corp. of Reno, Nevada in 2010.

\subsection{SAN PEDRITO GOLD DEPOSIT}

The San Pedrito prospect was explored by Freeport in 1985-1989 which drilled 5 holes in 1988 at Las Minitas to test a series of NNE-trending veins, and at Cerro Cristal.

\subsection{SANTA ROSA GOLD MINE}

The UNDP explored the Santa Rosa gold deposit in 1967-1969 (Table 12). Shallow drilling was carried out at Alto de la Mina (ADLM) by DGRM in 1975. The deposit was explored by Transworld Exploration S.A. in 1983-1986 and 
Freeport Exploration Company of New Orleans in 1986-1990, which defined a maiden resource of $11 \mathrm{Mt}$ at $1.6 \mathrm{~g} / \mathrm{t} \mathrm{Au}$. Freeport pulled out of Panama after the US invasion in 1989 and sold the deposit to Greenstone Resources Ltd of Toronto in 1990 in a 49-51\% joint venture with Boliden International Mining A.B. of Stockholm, Sweden, through the operating company Minas Santa Rosa S.A. Greenstone gained 100\% ownership in 1993. Greenstone produced about 119,000 ounces $(3,700 \mathrm{~kg})$ of gold from 1995-1999 in an open-pit, heap leach operation (Figure 21B). The mine closed prematurely caused by the low gold price, low recoveries and high debt, leading to the bankruptcy of Greenstone. The total mineable resources in 1996 were $26.5 \mathrm{Mt}$ at $1.38 \mathrm{~g} / \mathrm{t} \mathrm{Au}$ containing 36.5 t (1.175 Moz) gold (Greenstone Resources, 1996). The remaining total resources in 1998 were $19.7 \mathrm{Mt}$ grading $1.43 \mathrm{~g} / \mathrm{t}$ containing $28.1 \mathrm{t}(0.905 \mathrm{Moz})$ of gold (Greenstone Resources, 1998).

The project was reactivated in 2009 by private company Veragold Mining Company Inc. of Panama. Following a drill program in 2012-2013, it estimated resources in 2016 of $21.0 \mathrm{Mt}$ at $1.16 \mathrm{~g} / \mathrm{t}$ $\mathrm{Au}(24.3 \mathrm{t}$ or $0.78 \mathrm{Moz})$ measured and indicated plus $3.4 \mathrm{Mt}$ at $1.80 \mathrm{~g} / \mathrm{t}(6.2 \mathrm{t}$ or $0.20 \mathrm{Moz})$ inferred in three deposits, Alto de la Mina, Santa Rosa and Cerro Otero, in addition to $5.0 \mathrm{Mt}$ at 0.75 $\mathrm{g} / \mathrm{t} \mathrm{Au}(3.7 \mathrm{t}$ or $0.12 \mathrm{Moz})$ on the old leach pads

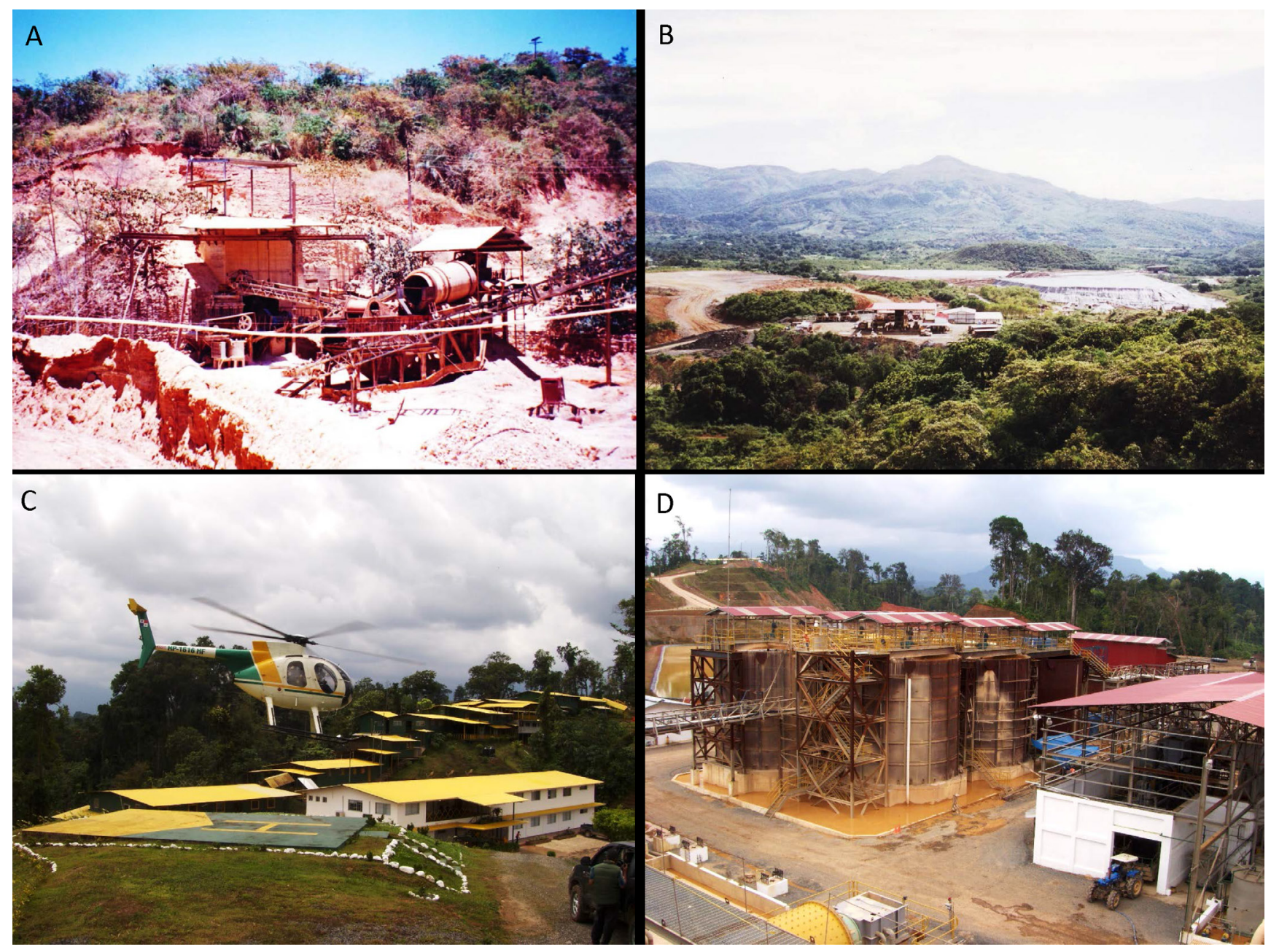

Figure 21 Gold mining in the 1990s to 2010s. A) The crusher and ball mills which fed a 200 tpd carbon-in-pulp (CIP) plant at the Remance gold mine in March 1994. It operated from 1990-1998, the first gold mine in Panama in 50 years. March 1994. B) The heap leach pad and gold recovery plant at the Santa Rosa gold mine, June 1997. It was mined from 1995-1999. C) The Molejon mine camp and office with a Hughes 500 helicopter, March 2009. Gold was mined from 2009-2014. D) The gold CIP leach tanks with 2,200 tpd capacity at the Molejon processing plant, March 2009. (Photographs by Stewart Redwood). 
Table 11. The history of the Remance gold mine.

\begin{tabular}{|c|c|}
\hline Year & Owners and Events \\
\hline 18th Century & Spanish Colonial mining until 1777. \\
\hline $1875-1880$ & José María Penavel mined. \\
\hline 1888 & Great Remance Gold Mining Mined. \\
\hline 1897 & Veraguas Mining Company, Glasgow mined 15,500 tons @ $10.4 \mathrm{~g} / \mathrm{t}$ for 5,183 oz. \\
\hline $1925-1932$ & $\begin{array}{l}\text { Panama Corporation Limited., England mined with } 100 \text { tpd cyanide plant. Mined } 14,000 \text { tons @ } 10.7 \\
\mathrm{~g} / \mathrm{t} \text { for } 5,332 \mathrm{oz} \text {, or } 70,000 \text { tons for } 27,124 \mathrm{oz} \text {. }\end{array}$ \\
\hline $1932-1945$ & The Panama Corporation (Canada) Limited, Montreal. \\
\hline$\sim 1945-1984$ & No activity. \\
\hline 1984-1988 & Transworld Exploration S. A. (TESA), Panama. \\
\hline $1987-1998$ & $\begin{array}{l}\text { Minera Remance S.A. (Ganoza family, Peru) operating contract with TESA. } 100 \text { tpd CIP plant, later } \\
300 \text { tpd. First gold poured April } 1990 .\end{array}$ \\
\hline Early 1990s & Cyprus Minerals Ltd. explored bulk mineable potential, drilled. \\
\hline 1995-1996 & $\begin{array}{l}\text { Northfield Minerals Inc., Toronto \& Pangold S.A. option to acquire the mine. Drilled } 30 \mathrm{RC} \text { holes and } \\
11 \mathrm{DDH} \text {. }\end{array}$ \\
\hline $1998-2000$ & Heron Exploration Inc., Quebec City bought Minera Remance S.A., drilled 96 DDH. \\
\hline 1998 & Mine closed. \\
\hline $2006-2010$ & Compañía Minera Clifton S.A. bought title from TESA. Concession expired 2010. \\
\hline 2010 & Pacific Rim Mining Corp., Reno, Nevada (Minera Verde S.A.) agreement with Clifton. \\
\hline
\end{tabular}

(Veragold website). The company is currently (2020) constructing a mine and a 500 tpd mill with plans to start production in 2020, and to progressively ramp-up the plant to 2,500 tpd in 2021 and 6,000 tpd in 2022.

\subsection{GERRO LAS MINAS GOLD PROSPECT}

The Cerro Las Minas epithermal Au prospect, located $3 \mathrm{~km}$ north of Cañazas, was explored by UNDP in 1966, Georecursos in 1991, Minnova Inc. in 1991-1992, and Arlo Resources in 1995-1996.

\subsection{GERRO GABALLO GOLD DEPOSIT}

The Cerro Caballo epithermal gold prospect was explored by Freeport Exploration, Greenstone Resources and BHP Minerals in the 1980s and 1990s. Eleven drill holes by Freeport in 1990 gave best intercepts of $41 \mathrm{~m}$ at $1.13 \mathrm{~g} / \mathrm{t} \mathrm{Au}, 56 \mathrm{~m}$ at 1.03 $\mathrm{g} / \mathrm{t} \mathrm{Au}, 24 \mathrm{~m}$ at $1.13 \mathrm{~g} / \mathrm{t} \mathrm{Au}$, with the highest grade of $3 \mathrm{~m}$ at $9.8 \mathrm{~g} / \mathrm{t} \mathrm{Au}$. It estimated a mineral resource of $2 \mathrm{Mt}$ at $1 \mathrm{~g} / \mathrm{t} \mathrm{Au}$.

\subsection{RÍO LIRI HIGH GOLD DEPOSIT}

The Río Liri high sulphidation gold deposit is located in the northwestern part of the Soná peninsula 65 $\mathrm{km}$ west of Santiago. The gold potential was first recognized by CEMSA of Panama in 1988. The Swedish Project reported Au above 200 ppb in five samples in 1990 (SGI, 1991a). It was explored by Minnova Inc. in 1991-1994 which identified the Cerro Pelado target. Arlo Resources Ltd. drilled 13 holes for 1,631 $\mathrm{m}$ in 1995, with best results of $41 \mathrm{~m}$ at $1.53 \mathrm{~g} / \mathrm{t} \mathrm{Au}, 14 \mathrm{~m}$ at $2.01 \mathrm{~g} / \mathrm{t} \mathrm{Au}, 26 \mathrm{~m}$ at 1.13 $\mathrm{g} / \mathrm{t} \mathrm{Au}$ and $34 \mathrm{~m}$ at $0.77 \mathrm{~g} / \mathrm{t} \mathrm{Au}$ (Folk, 2004a). Folk (2004a) estimated an inferred mineral resource of $1.66 \mathrm{Mt}$ at $1.35 \mathrm{~g} / \mathrm{t}$ Au in oxides containing 2,248 $\mathrm{kg}(72,288$ ounces) of gold. It was later explored by Bellhaven Ventures Inc., Vancouver in 2004-2006.

\subsection{GERRO GHORGHA Gu-Au PORPHYRY}

The Cerro Chorcha project lay dormant for almost two decades after Asarco dropped it in 1976 (Table 8). The project was staked by Consultores Geologicos S.A. of Panama in 1990 which formed the Geo-Minas S.A. joint venture with GeoRecursos International S.A. of Panama in 1993. It formed a joint venture with Arlo Resources Ltd. of Boise, Idaho, managed by its largest shareholder MK Gold Company of Salt Lake City, Utah, which carried out the first drilling in 1994-1995. It made a maiden resource estimate in 1995 of $265.9 \mathrm{Mt}$ grading $0.493 \% \mathrm{Cu}$ and $0.057 \mathrm{~g} / \mathrm{t} \mathrm{Au}$ at a cut-off 
Table 12. The history of the Santa Rosa gold mine.

\begin{tabular}{|c|l|}
\hline $\begin{array}{c}\text { Year } \\
\text { 17th-18th centuries }\end{array}$ & Spanish mining? \\
\hline Late 1800s & Small scale mining. \\
1882 & Messrs. Schuber and Farraud. \\
$1927-1940$ & Panama Corporation Limited, England small scale mining at Alto de la Mina (1927-1932) and Santa \\
Rosa (1935-1940). & UNDP exploration. \\
$1967-1969$ & DGRM drilled Alto de la Mina. \\
1975 & Transworld Exploration S.A. \\
$1983-1986$ & Freeport Exploration Company defined bulk minable deposit. Maiden resource 11 Mt @ 1.6 g/t Au. \\
$1986-1990$ & Greenstone Resources Ltd, Toronto and Boliden International Mining A.B., Sweden 49-51\% JV. \\
1990 & Formed Minas Santa Rosa S.A. operating company. \\
1993 & Greenstone 100\% \\
$1995-1999$ & Greenstone mined 119,000 oz Au by open pit, heap leach operation. \\
$2009-2020$ & Veragold Mining Company Inc., Panama exploration. \\
$2019-2020$ & Mine and plant construction. First production planned 2020 from 500 tpd plant with gravity and \\
& flotation, ramping up to 6,000 tpd in 2023.
\end{tabular}

of $0.20 \% \mathrm{Cu}$ (Folk, 2005). Further drilling was carried out by Cyprus Minerals in 1997-1998 (Folk, 2005).

The project was reactivated in 2005 by Cuprum Resources Corp. of Panama which was sold to Bellhaven Ventures Inc., later called Bellhaven Copper \& Gold Inc., of Vancouver. It drilled the project with partner Dominion Minerals Corp. of New York in 2007-2008, which bought Cuprum in 2009. A total of $10,546 \mathrm{~m}$ of diamond drilling was carried out in 47 holes since 1994. Bellhaven and Dominion estimated an indicated and inferred mineral resource in the Guariviara Zone of 202 Mt grading 0.49\% $\mathrm{Cu}$ and $0.07 \mathrm{~g} / \mathrm{t} \mathrm{Au}$ (cut-off $0.2 \% \mathrm{Cu}$ ), including a higher grade hypogene central zone of $37.4 \mathrm{Mt}$ at $0.93 \% \mathrm{Cu}$ and $0.16 \mathrm{~g} / \mathrm{t}$ $\mathrm{Au}$ (cut-off 0.65\% Cu) (Druecker and Sandefur, 2008). However, the Supreme Court of Panama ordered the suspension of exploration in 2010, citing community and environmental reasons, and the concession expired later that year.

\section{Discussion of exploration methods}

Gold was known in Panama since pre-Columbian era. In contrast, the discovery of copper in 19571971 resulted in the discovery of new porphyry copper belts. These were the only porphyry deposits known at the time between northern Mexico and southern Peru.

The main period of discovery in 1968-1992, comprised the porphyry copper discoveries in 1968-1971 and epithermal gold discoveries mainly in 1986-1992 (Figure 22A). There have been no discoveries since 1992, except for the brownfields discovery of the Balboa porphyry copper deposit in the Cobre Panama porphyry district in 2011.

Eight porphyry and three epithermal deposits were discovered by regional exploration programs by international agencies and the Panamanian government (Figure 22B). Four deposits were discovered by Panamanian companies, showing the important role that national companies have played. This includes the discovery of Cerro Colorado by a small company formed by an American geologist working in Panama and two prospectors. The other six deposits were discovered by major mining companies. Surprisingly, junior Canadian and American mining companies made no discoveries, although they were strongly involved in the evaluation and mining of projects since 1990.

The most successful generative exploration method was stream sediment sampling which resulted in the discovery of ten deposits (Figure 22C). Another six deposits, including five gold 

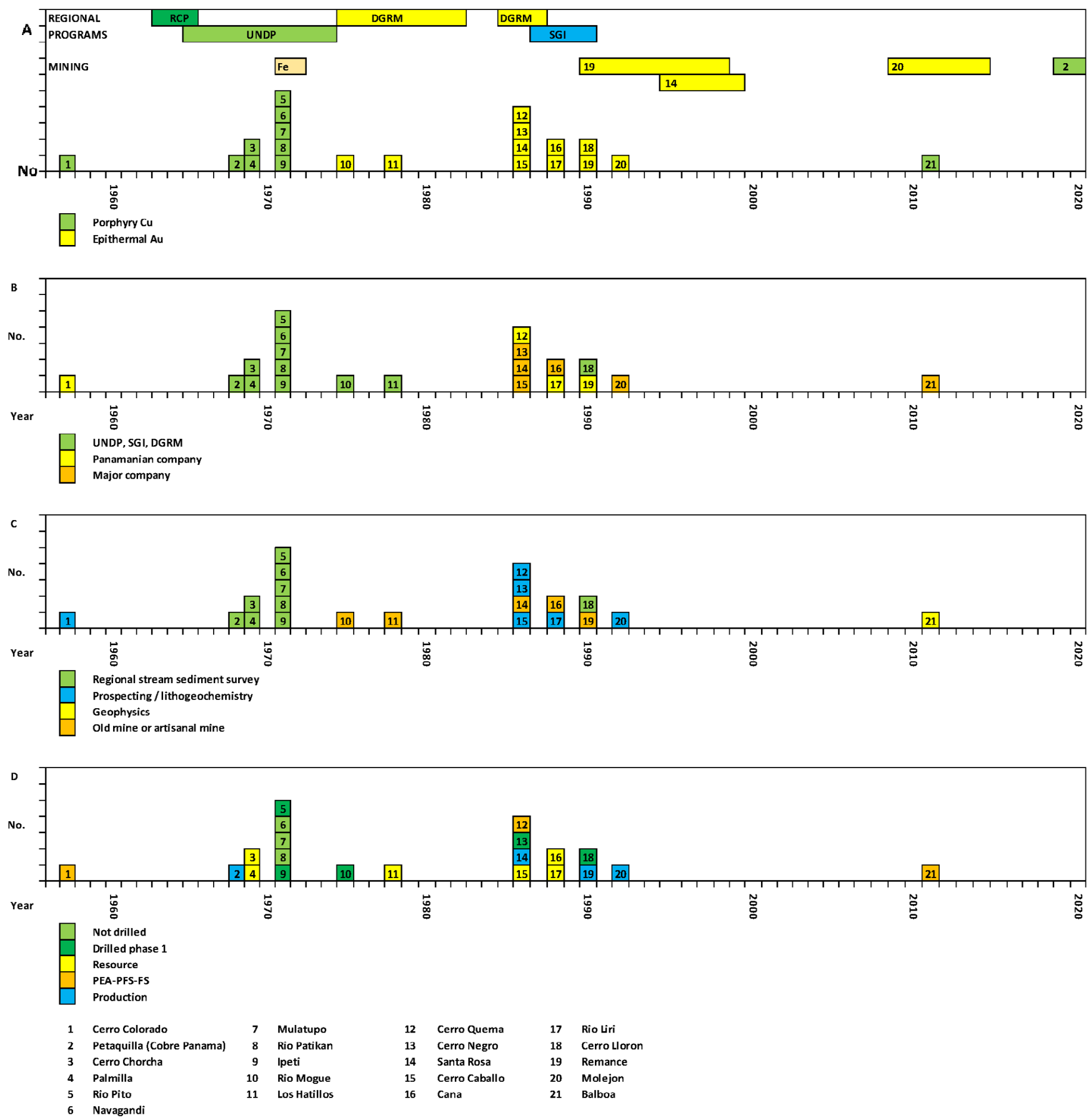

Figure 22 The discovery history of the copper and gold deposits of Panama. A) Year of discovery. The top rows show the regional exploration programs. The next two rows show the periods of mine production. B) Organization or company which made the discovery. C) Discovery method. D) Current economic status of the project. Abbreviations: DGRM, General Directorate of Mineral Resources. RCP, Rural Cadastral Project. SGAB, Swedish Geological International. UNDP, United Nations Development Programme. Fe, Hierro Panama iron ore mine. PEA, preliminary economic assessment (scoping study). PFS, preliminary feasibility study. FS, feasibility study. 
deposits, were discovered by lithogeochemical sampling of outcropping alteration zones, including Cerro Colorado that was found based on a historical report of a copper occurrence. Five other gold deposits were found by reexamination of old mines. Evaluation methods at the project stage were soil geochemistry and lithogeochemistry, trenching and early drilling with portable drill rigs, often within months of the initial discovery or concession award. Only one concealed deposit was discovered, the Balboa porphyry copper deposit, using geophysics.

Three of the gold deposits were mined, one of which is planned to restart mining in 2020, and one of the porphyry copper deposits began production in 2019, with a time lapse of 51 years from discovery (Figure 22D). Another three deposits have economic studies and six others have resources, while five have only had a first pass of drilling, and three have not been drilled.

The lack of discoveries in the last three decades, combined with almost all discoveries having been made of outcropping mineralization and the lack of concealed discoveries, indicates that the level of exploration is immature, and that there is a high potential for the discovery of additional deposits.

\section{Conclusion}

This study has examined the history of mining in Panama over the last two millenia in a complex island arc and collisional terrain in a tropical climate with dense vegetation, high rainfall and deep saprolitic weathering. Mining has progressed through several stages from indigenous gold mining, a Spanish colonial gold rush, small scale gold and manganese mining, followed by systematic exploration programs and discovery of major copper and gold deposits. All of the porphyry copper deposits were found in outcrop using stream sediment, soil and rock sampling, except for one concealed deposit at Balboa. The regional exploration programs covered two-thirds of the country but the stream sediment samples were not analyzed for gold, indicating that there is potential for undiscovered gold mineralization. The gold deposit discoveries were made in outcrop by lithogeochemical sampling or by reexamination of old mines. There have been no new discoveries in almost thirty years as a result of an out of date mining law. All of these factors indicate that the level of exploration in immature and that there is high potential for the discovery of new deposits.

\section{Acknowledgements}

The following people are thanked for their help over the years: Colin Burge of Inmet/First Quantum Mining, Panama and Vancouver, for information on Cobre Panama; Timo Mäki, formerly of Inmet Pyhäsalmi Mine Oy, Finland for tracking down the Petaquilla discovery photos and to Irja Huhta, Finland for permission to publish them; Carlos Carrasco, Minnova/Inmet, Panama, regarding Panama geology and exploration; Richard Cooke, Smithsonian Tropical Research Institute (STRI), Panama regarding archaeology and pre-Columbian gold; Warwick Bray, University College London regarding pre-Columbian gold and colonial mining history; John Griggs, Texas for sharing his research into the archaeology of the Petaquilla district and the Veraguas goldfields; Harriet Rae Beaubien, Smithsonian Institution, Washington for sharing her results of the Panama Goldwork project; Dan Buck, Washington for sharing historical research about the Emperador gold mine and other mines; Julia Mayo, El Caño Trust, Panama for showing me the pre-Columbian mines near La Pintada, and for sharing her archaeological papers; Sewall Menzel, Florida Atlantic University for information on Spanish Colonial coins and mints; Jorge A. Proctor for information on Spanish mints in Panama; Germinal Sarasqueta, Panama for providing me with the 1975 reprint of his grandfather Jose Oller's book and photos of the Cana mine, where he worked as the administrator; Stanley Heckadon Moreno, STRI, Panama for copies of his articles on Robert Stewart's discovery of Cerro Colorado; Robert Karman, Panama for permission to use the late John C. Doyle's Cerro 
Colorado discovery photos; Glyn Dawson, Chicago for permission to publish his photos of the old locomotives at Cana, and to Jeremy Martin, London, for identifying the locomotives; and to Ida Herrera, Panama for showing me the grinding stones on her property The manuscript benefitted from comments by Warwick Bray and Richard Cooke, and from reviews by Chris Torrey and Fabio Cediel. The maps were expertly drafted by José Cornejo Jr.

\section{References}

Agricola, G., 1556, De re Metallica: Basil, Hieronymus Froben \& Nicolaus Episcopus. English translation by Hoover, H.C, Hoover, L.H., London, The Mining Magazine, 1912. Alsop, J. D., Allen, R., 1986, A Darien epilogue: Robert Allen in Spanish America, 16981707: The Americas, 43, 197-201.

Anon, 1882, Les Mines D'Or de L'Isthme de Panama: L'Exploration: Journal des Conquêtes de la Civilisation Sur Tous les Points du Globe, 10, 707.

Archibald, R. D., Gibbs, B. L., Kunter, R. S., Martin, M. D., Solano-Rico, B., 2012, Molejon project, NI 43-101 technical report, Donoso District, Colon Province, Republic of Panama. NI 43-101 technical report by Behre Dolbear \& Company (USA) Inc. for Petaquilla Minerals Ltd., May 2012.

Arias, T., Griggs, J., 2004, La ilusión del oro: el Gobernador Juan López de Sequeira, su entrada y conquista de los coclé: Revista Cultural Lotería, 442, 24-39.

Awmack, H. J., 1992, Summary report on the Petaquilla Project: report for Adrian Resources Ltd., October 1992.

Bidwell, G. T., 1865, The Isthmus of Panama: London, Chapman and Hall.

Blas Aritio, L., 2014, Vasco Núñez de Balboa, La crónica de los cronistas de Indias: Panamá, Panamá, Ediciones Balboa.

Bray, W., Cooke, R. H., Redwood, S. D., 2021, Early metalwork in Caribbean Colombia and Lower Central America, in McEwan, C., Cockrell, B., Hoopes, J. W. (eds), Central American and Colombian Art at Dumbarton Oaks (Pre-Columbian Art at Dumbarton Oaks Series Number 5). Washington, D. C., Dumbarton Oaks, Trustees for Harvard University, in the press.

Brown, C. M., 1910, Tisingal: The lost mine of Panama: Colfax, Louisiana, The Colfax Chronicle, June 4, 1910, 6.

Bry, T. de, 1595, Americae pars quinta, nobilis \& admiratione plena Hieronymi Be[n]zoni ... secundae sectionis Hi[stori]a[e] Hispanorum tum in Nigrittas servos suos, tum in Indos crudelitatem, Gallorumq[ue] pirataru[m] de Hispanis toties reportata spolia [The Great or American Voyages, Part 5, Latin edition]: Frankfurt, Theodor de Bry.

Camus, Y., 2013, NI 43-101 Palmilla Deposit, Resource Update, Río Belencillo Zone 1 Concession, Colon Province, Panama: NI 43101 technical report by SGS Canada Inc. for Petaquilla Minerals Ltd., 29 October 2013.

Carles, R. D., 1962, Oro en Panamá: Revista Lotería, 7 (77), 40-41.

Carles, R. D., 1969, 220 años del periodo colonial en Panamá, Los Talleres de The Star \& Herald Company, 1948, 165 p; Panamá, Imprenta Nacional, 1959; Panamá, Departamento de Bellas Artes y Publicaciones del Ministerio de Educación, 1969, 294 p.

Casas, B. de las, 1561, Historia de las Indias: Madrid, Imprenta de Miguel Genesta, 1875, 5 volumes, Tomo III.

Castillero Calvo, A., 1967a, Descubrimiento y conquista de Veragua (1502-1560), in, Castillero Calvo, A., Estructuras Sociales y Económicas y de Veragua desde sus origenes históricos, Siglos XVI y XVII: Panamá, Editora Panamá, 29-49.

Castillero Calvo, A., 1967b, Los placeres auríferos de Concepción, in, Castillero Calvo, A., Estructuras Sociales y Económicas y de Veragua desde sus origenes históricos, Siglos XVI y XVII: Panamá, Editora Panamá, 53-87. 
Castillero Calvo, A., 1967c, Las Sabanas y la sociedad "señorial", in, Castillero Calvo, A., Estructuras Sociales y Económicas y Sociales de Veragua desde sus origenes históricos, Siglos XVI y XVII: Panamá, Editora Panamá, 91-137.

Castillero Calvo, A., 1973, Politica de poblamiento en la Castilla de Oro y Veraguas: Panamá, Editorial EUPAN.

Castillero Calvo, A., 1994, Conquista, Evangelización y Resistencia: Panamá, Instituto Nacional de Cultura.

Castillero Calvo, A., 2004, El oro y las perlas en la economía colonial, in, Castillero Calvo, A. (ed.), Historia General de Panamá: Panamá, Comité Nacional del Centenario de la República, I(II), El Orden Colonial, 431-456.

Castillero Calvo, A., 2008, Los metales preciosas y la primera globalización: Panamá, Imprenta Editora Novo Art.

Castillero Calvo, A., 2019, El oro y las perlas en la economía colonial, in, Castillero Calvo, A. (ed.), Nueva Historia General de Panamá: Panamá, Ciudad Comisión 500 Años de Fundación de la de Panamá, I(II), El Orden Colonial, 1541-1580.

Castillero Reyes, E. J., 1950, Leyendas e historias de Panamá La Vieja: Panamá, Producciones Erlizca.

Cedeño, D., 2002, Colón recorre la costa de Panamá, in Incer Barquero, J., Colón y la Costa Caribe de Centroamérica: Managua, Fundación VIDA, 191-202.

Chapman, R. J., Leake, R. C., Warner, R. A., Cahill, M. G., Moles, N. R., Shell, C. A., Taylor, J. J., 2006, Microchemical characterisation of natural gold and artefact gold as a tool for provenancing prehistoric gold artefacts: A case study from Ireland: Applied Geochemistry, 21, 904-918. https:// doi.org/10.1016/j.apgeochem.2006.01.007

Colón, F., 1571, Historia del Almirante Don Cristóbal Colón: Madrid, Spain, 1892 edition, Vol. 2.

Cooke, R. G., 2005, Prehistory of Native Americans on the Central American Land
Bridge: Colonization, Dispersal, and Divergence: Journal of Archaeological Research, 13, 129-187. https://doi. org/10.1007/s 10804-005-2486-4

Cooke, R. G., 2011, The Gilcrease Collection and Gran Coclé, in, Cooke, R.G., Hoopes, J.W., Quilter, J., Saunders, N.J., To capture the Sun: Gold of ancient America: Tulsa, Oklahoma, Gilcrease Museum, 114-159.

Cooke, R. G., Bray, W., 1985, The goldwork of Panama: An iconographic and chronological perspective, in, Jones, J., Kerr, J., The art of Precolumbian gold: The Jan Mitchell Collection: New York, The Metropolitan Museum of Art.

Cooke, R. G., Sánchez Herrera, L. A., 1998, Coetaneidad de metalurgia, artesanías de concha y cerámica pintada en cerro Juan Díaz, Gran Coclé, Panamá: Boletín Museo del Oro, 42, 57-85.

Cooke, R. G., Sánchez Herrera, L. A., 2019, Panamá Indígena: 1501-1550, in, Castillero Calvo, A. (ed.), Nueva Historia General de Panamá: Panamá, Ciudad Comisión 500 Años de Fundación de la de Panamá, I(I), Las Sociedades Originarias, 115-160.

Cooke, R., Isaza, I., Griggs, J., Desjardins, B., Sánchez, L. A., 2003, Who crafted, exchanged, and displayed gold in PreColumbian Panama?, in Quiler, J., Hoopes, J. W. (eds), Gold and power in ancient Costa Rica, Panama, and Colombia: Washington, D. C., Dumbarton Oaks Research Library and Collection.

Cooke, R. G., Hoopes, J. W., Quilter, J., Saunders, N. J., 2011, To capture the Sun: Gold of ancient Panama: Tulsa, Oklahoma, Gilcrease Museum.

Cooke, R., Ranere, A., Pearson, G., Dickau, R., 2013, Radiocarbon chronology of early human settlement on the Isthmus of Panama $(13,000-7,000 \mathrm{BP})$ with comments on cultural affinities, environments, subsistence, and technological change: Quaternary International, 301, 3-22.https://doi. org/10.1016/j.quaint.2013.02.032. 
Cooke, R. G., Wake, T. A., Martínez-Polanco, M. F., Jiménez-Acosta, M., Bustamante, F., Holst, I., Lara-Kraudy, A., Martín, J. G., Redwood, S., 2016, Exploitation of dolphins (Cetacea: Delphinidae) at a 6000 Yr old Preceramic site in the Pearl Island archipelago, Panama: Journal of Archaeological Science: Reports, 6, 733-756. https://doi.org/10.1016/j. jasrep.2015.12.001

Cooke, R. G., Sánchez Herrera, L. A., SmithGuzmán, N, Lara-Kraudy, A., 2019, Panamá Prehispanico, in, Castillero Calvo, A. (ed.), Nueva Historia General de Panamá: Panamá, Ciudad Comisión 500 Años de Fundación de la de Panamá, I(I), Las Sociedades Originarias, 39-114.

Craddock, P. T., Craddock, B. R., Langenscheidt, A., 2002, Stone mining hammers and their hafts from pre-Hispanic Mesoamerica: Mining History: The Bulletin of the Peak District Mines Historical Society, 15, 24-28.

Dampier, W., 1697, A new voyage round the world. London, James Knapton, 1697 and London, Hummingbird Press, 1998.

Davis, N., 1702, The Expedition of a Body of Englishmen to the Gold Mines of Spanish America, in 1702, with the many strange Adventures that befel them in that bold Undertaking, in Joyce, L. E. E. (ed.), Lionel Wafer's new voyage \& description of the Isthmus of America: Oxford, The Hakluyt Society, 2 (73), 152-165.

del Giudice, D., 1965, Los depositos goetiticos de La Mesa, Provincia de Veraguas, Republica de Panamá: Report, Panamá, Dirección General de Recursos Minerales, DDG/11.

del Giudice, D., Recchi, G., 1969, Geología del área del projecto minero de Azuero: Report, Panama, United Nations, 48 p.

Denyer, P., 2001, Las leyendas de las minas de Tisingal y La Estrella en Costa Rica: Revista Geológica de América Central, 25, 49-62.

Dickau, R., Redwood, S. D., Cooke, R. G., 2013, A 4000-year-old shaman's stone cache at Casita de Piedra, western Panama: Archaeological and Anthropological Sciences, 5, 331-349.https://doi.org/10.1007/ s12520-012-0112-5.

Dirección General de Recursos Minerales (DGRM), 1991, Mapa Geológico, Republica de Panamá, 1:250,000 scale: Panamá, Ministerio de Comercio e Industrias, 8 sheets. Druecker, M. D., Sandefur, R. L., 2008, Update Report on the Cerro Chorcha Porphyry Copper Project, Chiriqui and Bocas del Toro Provinces, Republic of Panama: NI 43-101 technical report for Bellhaven Copper \& Gold Inc. and Dominion Minerals Corp.

Durán, E., 1998, Polémica Sobre las Minas de Cana: Es Verde el Color del Oro?: Panama, La Prensa, 30 July 1998.

Emmons, W. H., 1937, Gold deposits of the World: New York, London, McGraw-Hill Book Company, Inc.

Esquemeling, J., 1911, The Buccaneers of America: London, George Allen \& Company, Ltd.

Exquemelin, A. O., 1685, Bucaniers of America.

The Second Volume: Containing the Dangerous Voyage and Bold Attempts of Captain Bartholomew Sharp, and others; performed upon the Coasts of the South Sea, for the space of two years, \&c. From the Original Journal of the said Voyage written by Mr. Basil Ringrose: London: Printed for William Crooke.

Ferenčić, A., 1970, Porphyry Copper Mineralization in Panama: Mineralium Deposita, 5, 383-389.

Ferenčić, A., 1971, Metallogenic provinces and epochs in Southern Central America: Mineralium Deposita, 6, 77-88.

Fernández de Oviedo, G., 1526, Sumario de la natural historia de las Indias: Toledo, Spain, Chapter 82, De las minas del oro. English translation Stoudemire, S. A., 1959, Natural History of the West Indies: Chapel Hill, North Carolina, University of North Carolina Press.

Fischer, T., 1975, Empresas extranjeras en el sector del oro y de la plata en Colombia, 1870-1914: la free-standing company como modelo 
aplicado por inversionistas extranjeros: Boletín Cultural y Bibliográfico, 32, 61-84.

Folk, P. G., 2004a, Report on the Río Liri Project, Veraguas and Chiriqui Provinces, Republic of Panama: NI 43-101 technical report for Bellhaven Ventures Inc., 22 p.

Folk, P. G., 2004b, Report on Veraguas Project, Veraguas Province, Republic of Panama: Higui (Zone 1), Hatillos (Zone 2), San Pedrito: NI 43-101 technical report for Bellhaven Ventures Inc., 23 p.

Folk, P. G., 2005, Report on the Chorcha Project, Chiriqui and Bocas del Toro Provinces, Republic of Panama: NI 43-101 technical report for Bellhaven Ventures Inc., 64 p.

Foster, D. F., 1939, Report on San Jose Hill, Darien, R. de Panama: Report for Panama Corporation (Canada) Ltd., University of Wyoming, American Heritage Center, Thayer Lindslay Papers, Box 204, Folder 1, $7 \mathrm{p}$.

Galeote, M., 2016. Apuntaciones históricolinguísticas sobre batea: Linguística y Literatura, 69, 217-227. http://dx.doi. org/10.17533/udea.lyl.n69a09

Gjording, C. N., 1991, Conditions not of their choosing: The Guaymí Indiams and Mining Multinationals in Panama: Washington and London, Smithsonian Institution Press.

Gray, D., Lawlor, M., Stone, R., 2019, Cobre Panamá Project, Colón Province, Republic of Panamá, NI 43-101 Technical Report: NI 43-101 technical report by First Quantum Minerals Ltd.

Greenstone Resources, 1996, Annual report: Greenstone Resources Ltd, Toronto.

Greenstone Resources, 1998, Annual report: Greenstone Resources Ltd, Toronto.

Griggs, J., 1998, A Preliminary archaeological study of the Petaquilla Concession, Colon Province, Republic of Panama: Report for Teck Corp.

Griggs, J. C., 2005, The archaeology of Central Caribbean Panama: Austin, Texas, The University of Texas at Austin, unpublished $\mathrm{PhD}$ thesis, $\mathrm{xxix}+420 \mathrm{p}$.
Gutiérrez, E. M., 1999, Relatos y anécdotas sobre las minas de Bique: El Panamá América, 21 December 1999.

Hargreaves, D., 1974, Feasibility studies outline Cerro Colorado development: Mining Magazine, 131(2), 86-97.

Harrison, T., 1857, Map of the Isthmus of Panama representing the line of the Panama Rail Road: New York, Endicott \& Co.

Harrison, A., Beaubien, H. F., 2010, Bringing context to the Smithsonian Collections of Pre-Columbian gold from Panama through technical examination and analysis, In, Metal 2010, Proceedings of the Interim Meeting of the International Council for Museums - Committee for Conservation (ICOM-CG) Metal Working Group, Charleston, South Carolina, 11-15 October 2015, 198-203.

Heckadon-Moreno, S., 2012a, El Geólogo Robert H. Stewart en Chiriqui Oriente, 1957: Epocas (Panamá), 27(9), 10-11.

Heckadon-Moreno, S., 2012b, El geólogo Robert Stewart en la Serranía de Tabasará, 1957: Epocas (Panamá), 27(10), 10-11.

Heckadon-Moreno, S., 2012c, Robert Stewart y el cobre de Cerro Colorado, 1957: Epocas (Panamá), 27(11), 4-5.

Hernández, E., 1996, Vocabulario en lengua castellana y mexicana de Fray Alonso de Molina: Estudio de los indigenismos léxicos y registro de las voces españolas internas: Madrid, CSIC.

Huhta, J. V., 1991, Discovery of Porphyry Copper Mineralization at Cerro Petaquilla, in Porphyry Copper, Molybdenum and Gold Deposits, Volcanogenic Deposits (Massive Sulphides), and Deposits in Layered Rocks: American Institute of Mining, Metallurgical and Petroleum Engineering, Case Histories of Mineral Discoveries, 3, 39-40.

Hull, C. F. H., 1940, Panama Corporation (Canada) Limited: Report for Panama Corporation (Canada) Ltd., University of Wyoming, American Heritage Center, Thayer Lindslay Papers, Box 204, Folder 1, $8 \mathrm{p}$. 
Inmet Mining Corporation, 2011, Inmet's Balboa Copper-Gold Discovery: webcast presentation, June 1, 2011.

Jane, C., 1930, The Voyages of Christopher Columbus, Being the Journals of his First and Third, and the Letters Concerning his First and Last Voyages, to Which is Added the Account of his Second Voyage Written by Andres Bernaldez: London, The Argonaut Press.

Jopling, G. F., 1994, Indios y negros en Panamá en los siglos XVI y XVII: Selecciones de los documentos del Archivo General de Indias: Antigua, Guatemala, Centro de Investigaciones Regionales de Mesoamérica, and South Woodstock, Vermont, USA, Plumsock Mesoamerican Studies.

Joyce, L. E. E. (ed.), 1934, Lionel Wafer's New Voyage \& Description of the Isthmus of America: Oxford, The Hakluyt Society .

Karrer, R. J., 2012, To Mint or Not to Mint.... That Is The Question:... or, Articles on the Same Subject by Jorge Proctor and Sewall Menzel: Charleston, South Carolina: Isthmian Collectors Club Journal, 12-5, 39-46.

Kents, P., 1968, Botija-Petaquilla Copper Porphyries, Panama: Report No. 523, Department of Technical Cooperation for Development, United Nations, New York, 23 October 1968.

Kvaerner Metals, 1997, Cerro Colorado Copper Project. Leach, SX-EW Prefeasibility Study: Report for PanaCobre S. A. Panama.

Kvaerner Metals, 1998, Cerro Colorado Copper Project. Leach, SX-EW Feasibility Study: Report for PanaCobre S. A., Panama.

Lach-Szyrma, G. W., 1909, The Darien, Republic of Panama: The South American Journal, 14 August 1909, 177.

Langenscheidt, A., 2009, El oro en el área mesoamericana: Arqueología Mexicana, 99, 20-23.

La Niece, S., 1998, Metallurgical Case Studies from the British Museum's Collections of
pre-Hispanic Gold: Boletín Museo del Oro, 44, 139-157.

Linn, K. O., Wieselmann, E. A., Galay, I., Harvey, J. J. T., Tufino, G. F., Winfield, W. D., 1981a, Geology of Panama's Cerro Colorado Porphyry Copper Deposit: Part 1: History and Setting: Mineral Energy Resources, Colorado School of Mines, 24(5), 1-14.

Linn, K. O., Wieselmann, E. A., Galay, I., Harvey, J. J. T., Tufino, G.F., Winfield, W.D., 1981b, Geology of Panama's Cerro Colorado Porphyry Copper Deposit: Part 2: Structure, Mineralization and Mineral Inventory: Mineral Energy Resources, Colorado School of Mines, 24(6), 1-14.

Lloyd, J. A., 1829, The Isthmus of Darien, Between Chagres, Porto Bello and Panama: map surveyed in 1828-29, in Webster, E. C., 1984, The Defense of Porto Bello: Panama, The Florida State University Isthmian Anthropology Society, 1970; Panama, Panama Historical Society, 1983, 1984.

Lothrop, S. K., 1937, Coclé, an archaeological study of Central Panama, Part 1. Memoirs of the Peabody Museum of Archaeology and Ethnology 7. Cambridge, Harvard University.

Lothrop, S. K., 1956, Jewelry from the Panama Canal Zone: Archaeology, 9, 34-40.

Low, V. F. S., 1931, Panama: The Mining Magazine, 44, 201-209.

Martín, J. G., Cooke, R. G., Bustamante, F., Holst, I., Lara, A., Redwood, S., 2016, Ocupaciones prehispánicas en Isla Pedro González, Archipiélago de las Perlas, Panamá. Aproximación a una cronología con comentarios sobre las conexiones externas: Latin American Antiquity, 27, 378-396.https://doi. org/10.7183/1045-6635.27.3.378

Mayo Torné,J., Carles J., eds., 2015, Guerreros de Oro: Los Señores de Río Grande: Panama, Editora del Caribe.

Mayo Torné, J., Mayo Torné, C., 2013, El descubrimiento de un cementerio de élite 
en El Caño; Indicios de un patrón funerario en el Valle de Río Grande, Coclé, Panama: Arqueología Iberoaméricana, 20, 3-27. https://doi.org/10.5281/zenodo. 1311235

Mayo, J., Mojica, A., Ruiz, A., Moreno, E., Mayo, C., Itzel de Gracia, G., 2007, Estructuras arquitectónicas incipientes y áreas de explotación minera prehispánica de las cuencas de los ríos Grande y Coclé del Sur, Panamá: Revista Española de Antropología Americana, 37, 93-110.

Mealey, G. A., 1996, Grasberg: Mining the Richest and Most Remote Deposit of Copper and Gold in the World, in the Mountains of Irian Jaya, Indonesia: New Orleans, FreeportMcMoran Copper \& Gold.

Mena García, C., 201 1, El oro del Darién: Entradas y cabalgadas en la conquista de Terra Firme (1509-1525): Fundación Pública Andaluza, Centro de Estudios Andaluces, Seville and Consejo Superior de Investigaciones Científicas, Madrid, 640 p.

Méndez, A., 2013, Reseña histórica de la actividad minera en Panamá. Historical summary of mining activity in Panama: Panamá, Planeta Minero, 12, 4-8.

Mérida, J. E., 1973, Contribución a la historia de la exploración y explotación minera en Panamá: Panama, Dirección General de Recursos Minerales (DGRM). Unpublished report.

Mérida, J. E.,1995, History and the location of old gold mines in the Capira area from XIX-century archives of Bogota, Colombia. Unpublished report.

Navarette, M. F. de, 1922, Viajes de Cristóbal Colon: Madrid, Espasa Calpe, S.A.

Nelson, C. E., 1995, Porphyry copper deposits of Southern Central America, in, Pierce, F. W., Bolm, J. G. (eds), Porphyry copper deposits of the American Cordillera: Arizona Geological Society Digest, 20, 553-565.

Nelson, G. E., 2001, Gold Mineralization in Dome Fields of the Veraguas Belt, Panama: Society of Economic Geologists Special Publication,
8, 307-316. https://doi.org/10.5382/ SP.08.19

Nocete, F., Sáez, R., Navarro, A. D., San Martin, C., Gil-Ibarguchi, J. I., 2018, The gold of the Carambolo Treasure: New data on its origin by elemental (LA-ICP-MS) and lead isotope (MC-ICP-MS) analysis: Journal of Archaeological Science, 92, 87-102. https:// doi.org/10.1016/j.jas.2018.02.011

Norton, H. K., 1932, Why Britishers in Panama?, in St. Lawrence Waterway, Hearings before a subcommittee of the Committee on Foreign Relations, United States Senate, 72nd Congress, 2nd Session on Senate Resolution 278: Washington, United States Government Printing Office, 147-150.

Oller, J., 1933, La Industria Minera en Panama: Panamá, Biblioteca Cultura Nacional, 19, 193-214.

Oller, J., 1975, La Industria Minera en Panama: Panamá, 2nd edition.

Panama Mineral Resources Development Co. Ltd. (PMRD), 1977, Preliminary Feasibility Report of Petaquilla Project, the Republic of Panama: unpublished report.

Patterson, S. H., 1967, Bauxite Reserves and potential aluminum resources of the world: U. S. Geological Survey Bulletin, 1228.

Patterson, S. H., Kurtz, H. F., Olson, J. C., Neeley, C. L., 1986, World bauxite resources: geology and resources of aluminum: United States Geological Professional Paper, 1076-B, B1-B151.

Pearson, G. A., 2003, First report of a newly discovered Paleoindian quarry site on the isthmus of Panama: Latin American Antiquity, 14, 311-322. https://doi. org/10.2307/3557563

Posada, F., 1898, Directorio General de la Ciudad de Panamá: Panama, Imprenta Star and Herald.

Proctor, J. A. 2010, La Casa de la Moneda de Panamá del Siglo XVIII: Boletín Numismático (NUMISCOL, Fundación Numismáticos Colombianos), 89, 22-31. 
Quirós, J. L., 1962, Los Minerales de Panama: Panamamerica, April 1962, 6.

Quirós, J. L., 1975, Apuntes Sobre Recursos Minerales en Panama: Panamá, Direccion General de Recursos Minerales.

Ramusio, G. V., 1556, Terzo Volume Delle Navigatione et Viaggi: Venice, Stamperia de Giunti.

Redwood, S. D., 2020a, The Island of Dr No: The Industrial Heritage of Boná Island, Panama: Tales of Old Panama and Castilla Del Oro, 1(3), 3-12.

Redwood, S. D., 2020b, The Lost Gold Mine in the Panama Canal Zone: Tales of Old Panama and Castilla del Oro, 1(4), 3-16.

Redwood, S. D., 2020c, The Mineral deposits of Panama: Arc metallogenesis on the trailing edge of the Caribbean large igneous province: Boletín de la Sociedad Geológica Mexicana, 72(3), A130220. http://dx.doi. org/10.18268/BSGM2020v72n3a130220

Restrepo, V., 1886, A Study of the Gold \& Silver Mines of Colombia. English translation of 1884 edition by G. W. Fisher: New York, Colombian Consulate.

Restrepo, V., 1888, Estudio Sobre las Minas de Oro y Plata de Colombia: Bogotá, Colombia, Banco de la Republica, 2nd edition.

Restrepo, V., 1952, Estudio Sobre las Minas de Oro y Plata de Colombia: Bogotá, Colombia, Banco de la Republica, 4th edition.

Reverte Coma, J. M., 1961, San Vicente de Bique, ruinas olvidadas: El Panamá América, Suplemento Dominical, 10 December 1961.

Riddell, G. C., 1927, Is mining to thrive again in Panama?: Engineering and Mining Journal, 124 (17), 649-653.

Rippy,J. F., 1953, British investments in Colombian mines: Inter-American Economic Affairs, 7, 65-72.

Roberts, R. J., Irving, E. M., 1957, Mineral Deposits of Central America, with a section on Manganese Deposits of Panama: United States Geological Survey Bulletin, 1034.
Rovira, S., 1994, Pre-Hispanic goldwork from the Museo de América, Madrid: a new set of analyses, in Archaeometry of pre-Columbian sites and artifacts: In Scott, D. A., Meyers, P., (ed.), Proceedings of a symposium organized by the UCLA Institute of Archaeology and the Getty Conservation Institute, Los Angeles, California, March, 1992, 323-350.

Sánchez Herrera, L. A., 2007, Reporte tipológico y cronológico de los componentes cerámicos de Cerro Cebollal (LP-134), La Pintada, provincia de Coclé: Revista Española de Antropologia Americana, 37, 159-178.

Sarcina, A., 2017, Santa Maria de la Antigua del Darién, la primera ciudad española en Terra Firme: una prospección arqueológica sistemática. Santa Maria de la Antigua del Darién, the First Spanish City in Terra Firma: A Systematic Archaeological Prospection: Revista Colombiana de Antropologia, 53(1), 269-300.

Sears, J. D., 1919, Deposits of Manganese Ore in Costa Rica and Panama: United States Geological Survey Bulletin, 710-C, 61-91.

Sheridan, J. F., 1926, Gold areas of the province of Panama: Engineering and Mining Journal, 122(26), 1027-1028.

Simon, J., 1914, Manganese mines located near harbor of Nombre de Dios, Panama: Report for Panaminas, Inc., University of Wyoming, American Heritage Center, Thayer Lindslay Papers, Box 203, Folder 5, 14 p.

Simons, F. S., 1957, Manganese Deposits of Panama, in Roberts, R. J., Irving, E. M., Mineral Deposits of Central America, with a section on Manganese Deposits of Panama: United States Geological Survey Bulletin, 1034, 106-135.

Smith-Guzmán, N. E., Sánchez Herrera, L. A., Cooke, R. G., Bray, W. M., Díaz, C. P., Jiménez Acosta, M., Redwood, S. D., Ranere, A., 2021, Resurrecting Playa Venado, A PreColumbian Burial Ground in Panama, in McEwan, C., Cockrell, B., Hoopes, J. W. 
(eds.), Central American and Colombian Art at Dumbarton Oaks (Pre-Columbian Art at Dumbarton Oaks, Number 5): Washington, D. C., Dumbarton Oaks, Trustees for Harvard University, in the press.

Speidel, F., Faure, S., Smith, M. T., McArthur, G. E., 2001, Exploration and Discovery at the Petaquilla Copper-Gold Concession, Panama, Central America: Society of Economic Geologists Special Publication, 8, 349-362. https://doi.org/10.5382/SP.08.23

Stewart, R. H., 1957, A geological report of new mineral prospects north of San Felix, Province of Chiriqui, Republic of Panama: unpublished report (cited by Linn et al., 1981a).

Stewart, R. H., 1991, Stewart's Adventures, 1947-1966: unpublished memoirs (cited by Heckadon-Moreno, 2012a, 2012b, 2012c).

Stewart, R. H., Stewart, J. L., Woodring, W. P., 1980, Geologic map of the Panama Canal and vicinity, Republic of Panama. United States Geological Survey Miscellaneous Investigations Series Map I-1232, scale 1:100,000, 1 sheet.

Stranahan, D. M., 1941, Isthmian Corporation: Report, University of Wyoming, American Heritage Center, Thayer Lindslay Papers, Box 203, Folder 7, 2 p.

Swedish Geological International (SGI), 1991a, Geologia y ocurrencias de minerales en tres sectores en Panama. Informe Final, Parte I: unpublished report.

Swedish Geological International (SGI), 1991b, Mapeo geoquimico en tres sectores en Panama. Informe Final, Parte II: unpublished report.

Taylor, R. C., 1852, Substance of notes made during a geological reconnoissance [sic] in the auriferous porphyry region next to the Caribbean Sea, in the Province of Veraguas and Isthmus of Panama: Journal of the Academy of Natural Sciences of Philadelphia, 2nd Series, 2, 81-86.

Terry, R. A., 1956, A Geological Reconnaissance of Panama: Occasional Papers of the
California Academy of Sciences, 23.

Texasgulf, 1978, Cerro Colorado Project, Feasibility Study. Report on Geology: Unpublished report by Texasgulf Panama Inc. for Empresa de Cobre Cerro Colorado S.A., May 1978.

Tippett, M. G., Trever, P. F., 1989, The Isthmus of Panama: A Forgotten El Dorado: Society of Mining Engineers Preprint, 89-56.

Torrey, C. E., Keenan, J., 1994, Cerro Quema Project, Panama, in Bloom, L. (ed), Prospecting in Tropical and Arid Terranes short course: Toronto, Ontario, Prospectors and Developers Association of Canada, 5-6.

Tortelli, G., Lightwood, G., Brown, D., MacMahon, C., Hull, A., Gorman, M., Sutcliffe, R., Kuchling, K., Yassa, A., Wu, Y., Burga, D., Armstrong, T., 2014, Cerro Quema Project - Pre-Feasibility Study on the La Pava and Quemita Oxide Gold Deposits, 10,000 tpd Heap Leach: NI 43-101 technical report by $\mathrm{P} \&$ E Mining Consultants Inc., Golder Associates Inc. \& Kappes, Cassiday and Associates for Pershimco Resources Inc.

Tower, G. W., 1963, Cana mine, Panama: Report for Mauricio Hochschild, University of Wyoming, American Heritage Center, Thayer Lindslay Papers, Box 110, Folder 1, $8 \mathrm{p}$.

United Nations (UN), 1968, Report on Area 65 - Cerro Petaquilla, Province of Colón, Panamá: United Nations Development Programme, Mineral Survey of the Azuero Area, Publication No. 2.

United Nations (UN), 1969a, Porphyry Copper Mineralization at Cerro Petaquilla, Province of Colón, Panamá: United Nations Development Programme, Mineral Survey of the Azuero Area, Publication No. 3.

United Nations (UN), 1969b, Results of detailed investigations in the Azuero area, Panama: United Nations Development Program report to the Government of the Republic of Panama.

United Nations (UN), 1972a, Reconnaissance Geochemical Survey of Bocas del Toro, 
Majé, Pirre and San Blas-Darien. Panama Mineral Survey (Phase II), Technical Report No. 2: New York, United Nations.

United Nations (UN), 1972b, Preliminary investigation of copper, gold and related mineralization in San Blas and other selected areas in Panama. Mineral Survey (Phase II) Republic of Panama, Technical Report No. 3: New York, United Nations Development Programme.

United Nations (UN), 1972c, Reconocimiento de las mineralizaciones de cobre y oro en la región del Río Pito, Comarca de San Blas. Proyecto Minero (Fase II) Panama, Informe Tecnico No. 4: New York, United Nations Development Programme.

United Nations (UN), 1981, Exploracion para cobre y oro en Río Pito, Panama: New York, United Nations Development Programme.

Webster, E. C., 1984, The Defense of Porto Bello: Panama, The Florida State University Isthmian Anthropology Society, 1970. Panama, Panama Historical Society.

West, R. C., 1952, Colonial Placer Mining in Colombia: Baton Rouge, Louisiana State University Press.

Williams, A. R., Coventry, D., 2012, Los señores dorados de Panamá: National Geographic en Español, 30, 30-45.

Wilmot, R. G., 1960, Alumina and bauxite: U.S. Bureau of Mines Bulletin, 585, 15-26.

Wilson, F., 1981, The Conquest of Copper Mountain. A vivid, personal account of the discovery and development of a spectacular outcrop of ore in the remote peaks of Irian Jaya, Indonesia: New York, Atheneum.

Wleklinski, S., 1969, Gold deposits of northern Veraguas, Republic of Panama. United Nations Development Programme, Mineral Survey of the Azuero Area: New York, United Nations Development Programme.

Woakes, E. R., 1895, Notes on the Espiritu Santo Mine at Cana; Its Drainage and Recovery: Transactions of the Institution of Mining \& Metallurgy, 3, 285-297.

Woakes, E. R., 1899, Modern Gold-Mining in the Darien. Notes on the Reopening of the Espiritu Santo Mine at Cana: Transactions American Institution of Mining Engineers, 29, 249-280.

Woakes, E. R., 1923, The Darien Gold Mine, Panama: The Mining Magazine, November 1923, 270-278.

Woodring, W. P., 1957, Geology and Paleontology of Canal Zone and Adjoining Parts of Panama: Geology and Descriptions of Tertiary Molluscs (Gastropods: Trochidae to Turritellidae): United States Geological Survey Professional Paper, 306-A, Plate 1: Geological Map of Canal Zone and Adjoining Parts of Panama, 1:75,000 scale, Plate 2: Geologic Map of Gaillard Cut Area, Canal Zone, 1:25,000 scale.

Woodring, W. P., 1982, Geology and Paleontology of Canal Zone and Adjoining Parts of Panama: United States Geological Survey Professional Paper, 306-F, Plate 125: Geologic Map of the Panama Canal and Vicinity, Republic of Panamá. 